\title{
Visual Storytelling Interacting in School \\ Learning Conditions in the Social Science Classroom
}

\section{Linnéa Stenliden}

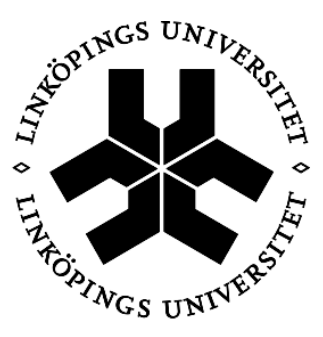

Linköping University

EDUCATIONAL SCIENCES 
Department of Social and Welfare Studies

Linnéa Stenliden

Visual Storytelling Interacting in School.

Learning Conditions in the Social Science Classroom

(C) Linnéa Stenliden, 2014

Omslagsillustration: Linda Fredriksson, Mikael Jern, Per Lagman, Linnéa Stenliden

Tryck: LiU-tryck, 2014

ISBN 978-91-7519-338-0

ISSN 1653-0101

Distribueras av:

Institutionen för samhälls- och välfärdsstudier

Linköpings universitet

SE-581 83 Linköping 


\section{Acknowledgement}

It has been a great privilege to be able to spend these years investigating my curiosities and learning the art of science. It has been an adventure made possible thanks to certain circumstances in life and the contribution of many. There are so many inputs, engagements and efforts that are the foundation of this thesis.

First of all, I would sincerely like to thank my supervisors: Jörgen Nissen for your amazing endurance and always reliable, confidant and enjoyable supervision, but also for guiding me into the academic world and your patience with my impatience; Eva Reimers for your, at all times, so open-eyed direction and sharp analytical sense; and Mikael Jern for introducing me to the realm of data visualization and for your remarkable energy and enthusiasm. Thank you all, for bringing me your different perspectives, for your knowledge and the discussions that have put this work forward.

Thanks also to the trustworthy partners at NCVA, where Patrik Lundblad and Tobias Åström always made my day. Nothing was ever a problem to you, no question was ever too stupid to ask, and I always felt at ease with you. For that I am ever so grateful.

Special thanks also to the teachers and the students that so bravely decided to participate in this study. Without your welcoming attitude and generosity with your time this dissertation could never have come about. You know, you are the first ones in the world!

I would also like to thank all senior researchers and fellow doctoral students within the Research School of Childhood, Learning and Didactics (RSCLD). ${ }^{1}$ It has been a privilege and an honour to be part

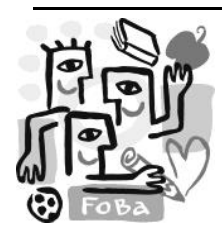

${ }^{1}$ The thesis was funded by the Swedish Research Council through the Research School of Childhood, Learning and Didactics (RSCLD). The research school is a collaboration between the University of Gothenburg, University of Karlstad, University of Kristianstad, Linköping University and Malmö University, as coordinator and host. 
of this first national research school with this focus.

Furthermore, I would like to express my deep gratitude to the many colleagues that read my manuscripts, critically commented on them and been giving me advice and support. For this I especially thank Polly Björk Willén, Sinna Lindquist, Anna Harrie Johansson, Lena Tibell, Ola Lindquist, Katarina Eriksson Barajas, Veronica Johansson and Frances Lee. I am also grateful to Susanne Severinsson and Adriana Velasquez who carefully read and commented drafts of my articles. I am in dept to Andreas Fejes, Maria Simonsson and Suzanne Parmenius Svärd who helped me indeed in the final phase. Your skilled remarks made me improve and sharpen the compilation part of the work tremendously.

Moreover, many thanks go to my colleagues at the Department of Social and Welfare Studies at Campus Norrköping; first to all of you within Educational Practices who make that to such a fruitful and cultivating research environment. Thank you for your positive attitudes and the boosting way you have delivered critical comments to me. In similar ways, the doctoral students have been my critical friends. Some have been by my side for a long time and some have joined later. Some have also become friends of my heart. You have all been absolutely crucial to me. Your trustful friendship, your always encouraging support and the many releasing laughs in the 'fika-room' always make me vitalized and sunnier. For this I would like to thank Jenny Bengtsson, Lina Söderman Lago, Linda Häll, Mats Bevemyr, Linnea Bodén, Anna Bylund, Katarina Elfström Petersson, Kirsten Stoewer, Lars Wallner, Rizwan-Ul Huq, Josefine Rostedt, Sara Dalgren, Anders Albinsson and Daniel Björklund. Other important people for me at my department have been Brith-Inger Aspgård, Kristina Fredriksson and Kicki Karlsson. Thank you for becoming awesome co-workers and dear friends. You always brighten my times.

Beside these relationships, friends and family have been an absolutely fundamental incitement for getting through this work. To all my friends, no one forgotten, thank you a million times for your love, encouragement and inspiration. You make me shine. 
My dearest thank you is directed to my mother and father who throughout my life always have supported me and made me believe in myself. You taught me, by your behaviour, that everything is possible whoever you are, you only have to work hard for it. That made me solid for which I am forever grateful.

For the most important in the world, however, words do not suffice. My dearest Jakob and Oskar, there are a lot of things during this time that also have affected you. My hope is though, that my attitude will also encourage you in life. Thanks a lot for helping me put things into perspective--it is really not difficult to write 0,1 A4 a day ;). Ola, my soul mate, my love, I would never have endured without you and your 'neglecting' attitude to this work. Knowing me best, this was the unwavering support I needed and also made me succeed. Thank you for holding out and holding on to all that really matters through everything that happened in all aspects of our life over these last years. You are amazing. 



\section{Table of Contents}

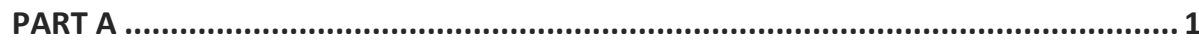

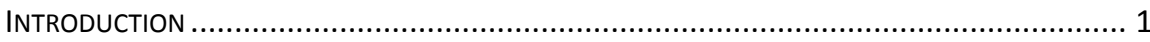

Data and Information Management ............................................................ 2

Education in-between Hope and Change...................................................... 4

Challenges for Educational Practice ............................................................. 6

Visual Storytelling and Geovisual Analytics ................................................. 7

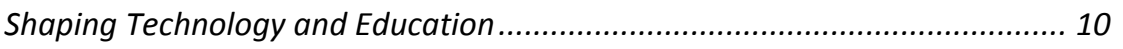

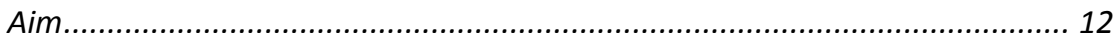

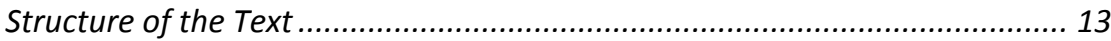

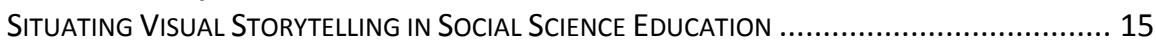

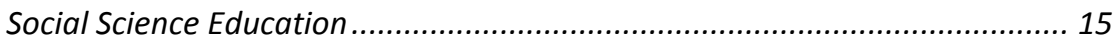

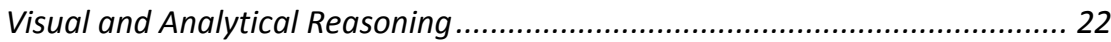

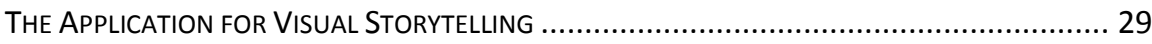

Production - Import Data, Explore and Gain Insight ................................... 29

Presentation - Toolkit and Interactive Features.......................................... 31

Dissemination - Publishing the Visual Story............................................. 32

A Vislet - The Story on a Web or a Blog.................................................. 32

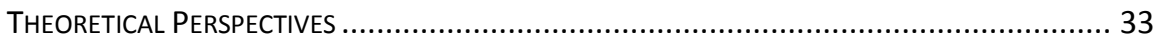

Theoretical Aspects and Interdisciplinarity................................................ 33

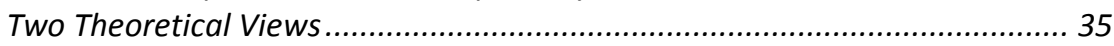

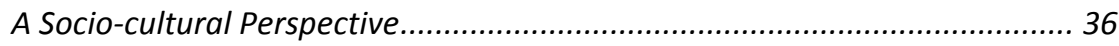

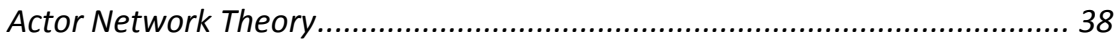

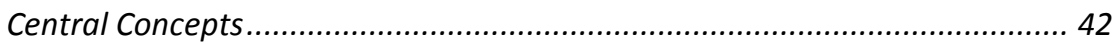

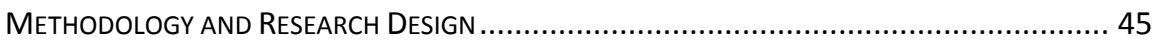

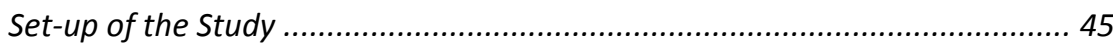

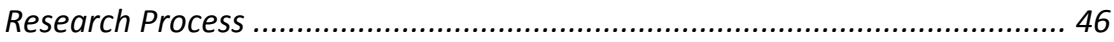

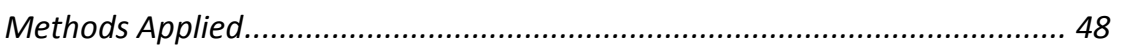

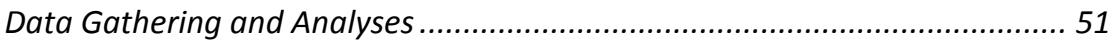

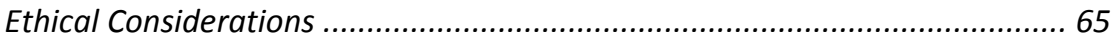

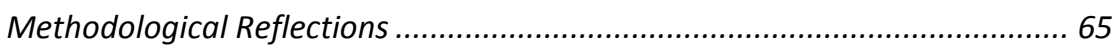

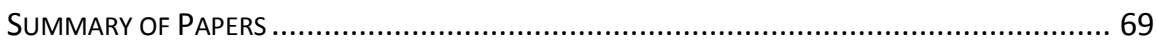

Visual Storytelling Technology in Relation to Teachers ............................... 69

Visual Storytelling Technology in Relation to Students................................ 71

A Socio-cultural Perspective - Implications for an Inquiry of Education
employing Visual Storytelling .................................................................. 72

Learning Activities and Learning Conditions............................................... 74

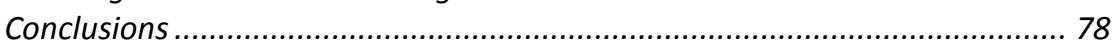

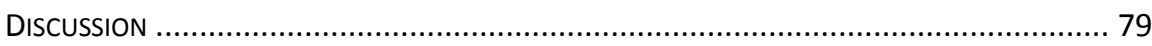

The Shape and Use of Visual Storytelling in Social Science Education - How Interactions Take Place ...................................................................... 79 
The Learning Conditions - Social Dimensions, Technical and Other Matters Matter. 81

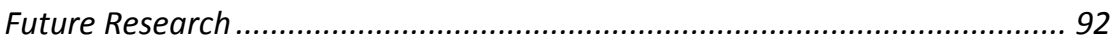

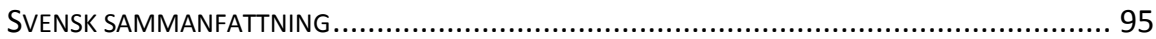

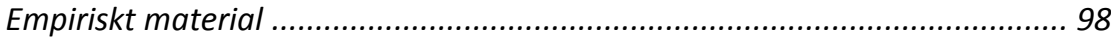

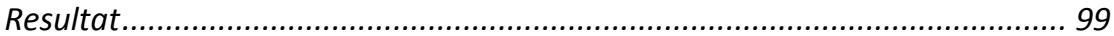

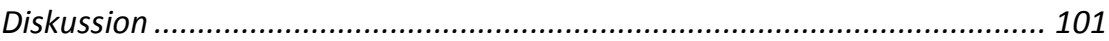

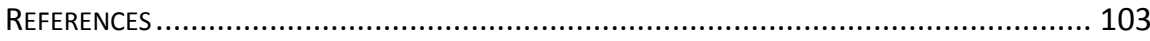

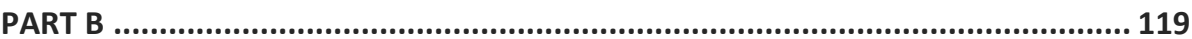

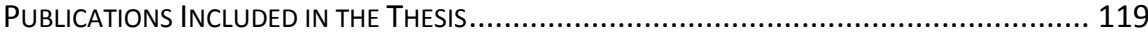

\section{APPENDIXES}




\section{Part A}

\section{Introduction}

The point of departure in this study is that education is closely intertwined with information and technology. The interest is in investigating relations between information, technology and students' knowledge formation, and the learning conditions that arise in social science classrooms where data visualization technology is introduced. The purpose is to understand how technology for visual storytelling can be shaped and used in relation to social science education in primary schools, and also how social dimensions, technology and other matters create emerging learning conditions in such educational settings. In the following sections different aspects will be explained that are seen as significant for the aim and the research questions formulated in this study, which are presented on page 12 .

Largely, as a result of the development of information and communication technology (ICT), today more data are produced and access to information is greater than ever before; as a result, the volume of available information is increasing rapidly. In the information and knowledge society, people are faced daily with the challenge of sorting, filtering, interpreting and evaluating huge quantities of information (for example, see Hilbert \& López, 2011; MayerSchönberger \& Cukier, 2013; Ohlhorst, 2013). This task is complex and the masses of information seem to create a messy or vague image of the world, making it difficult to develop knowledge or reach insights. For many, the conception of the world has also often become skewed (Rosling, et al. 2004; UNDP, 2007). This is paradoxical as the data are actually available in digital format on the Internet. Therefore, even though human communication has always been made up of multiple modes, humans are exploring different ways to link, transfer or make connections between these increasingly extensive and complex forms of information to facilitate the creation of knowledge (Bamford, 2003). Moreover, as Ludvigsen (2012) claims, one consequence of the production of and access to so much information in 
contemporary society is that now we are all expected to learn more. He puts forward that students of all ages are expected to manage larger amounts of information, develop additional abilities and create more knowledge than before. That includes all problem-solving activities, both inside and outside school. As a result, the ability to combine data and then use the results to perform analyses has become key (Chakravarty, 2008).

\section{Data and Information Management}

So, on one hand, there seems to be a risk that technology is currently producing more information, and also monitoring more information, than ever, challenging humans to deal with the situation (information and technology). But, on the other hand, there are institutions, most often outside school, that have started to use new approaches to cope with all this information and the cornucopia of data. In these cases, access to data and information has become a resource, similar to other resources in the world and even to technology itself (Siegel, 2013). It has been suggested that big data ${ }^{2}$ and information represent the $21 \mathrm{st}$ century's next frontier for innovation, competition, and productivity (Manyika et al., 2011). The information masses thus seem to have great potential and to be manoeuvrable.

In this connection, two distinct but related factors should be emphasized. These are shifts in (1) handling and (2) communicating information. The first is about a move away from the dominance of writing towards a new dominance of images. The second is about a move away from the dominance of the medium of books to the medium of screens (Kress, 2010). These shifts are attributable to the development of technologies, which play a central role; these include information and communication technology (ICT), visualization technology, scientific visualization technology, information visualization technology, visual analytics, and geovisual analytics, among

\footnotetext{
2 'Big data' is a phrase used to describe a massive volume of both structured and unstructured data that is so large that it's difficult to process using traditional database and software technologies. Big data comprises data sets where the three Vs - volume, velocity and variety - present specific challenges in managing the data within them (Laney, 2001).
} 
others. The potentials offered by visualization techniques have seen a huge rise during the last 15-20 years and play a major role in understanding the world (Chen, 2013). The adage 'a picture paints a thousand words' is demonstrated by these kinds of interactive media (Bamford, 2003). However, although this development has been triggered by the availability of computers and related technologies, the very essence of information visualization can be appreciated by looking at examples from long before the invention of computers (Tufte, 1983). Visualization is communication by images ranging from cave paintings to highly technological computer-based interactive images. Through the latter, humans and computers can now cooperate to achieve results. These kinds of visualizations have been defined as 'The use of computer-supported, interactive visual representations of data to amplify cognition' (Card et al., 1999, p. 7). This refers to how computers can show visualizations of different kinds of data or information and allow interactions between the visualizations and humans in order to learn from or with each other.

The combined effects of this shift in handling and communicating information will probably produce a deep change in human cognitive, cultural and bodily engagement with the world and the forms and shapes of knowledge (Kress, 2010). These technologies will probably have an impact on our views of the world (Rosling, 2007). Kress argues that 'the world told is a different world to 'the world shown' (2003, p. 1). The presentation of the world may be perceived differently, depending on how it is presented, as claimed by Weber and Mitchell (2008). This situation challenges education to emerge, to adapt to new tools and develop new methods (Jeffrey, 2009), which in turn demands that advanced visualization technologies be considered for use in education. But as Säljö neatly puts it: "mindwares do not think by themselves, even a complex mindware is still a mindware. But when such resources are integrated into most of what we do, and when they reach a level of complexity in which they process and analyse information relevant for social action, then our mastery of such tools is a critical element of what we know' (2010a, p. 63). This quotation highlights both the importance of the ability to use these kinds of tools and the significance of reflection on what they do with us and our knowledge formation. Without them we are probably today, not 
sufficiently able, to any great extent, to handle information or develop our knowledge. Prensky $(2009,2012)$ explains the current situation as one where it is no longer a matter of whether to use the technologies of our time but rather how to use them critically, to become better, more informed and wiser. We need to reflect on the technologies to be able to act with the help of 'digital wisdom' (ibid.). The technologies' role, their enrolment of human identities and their influence on learning and education are most often taken for granted and often become almost invisible.

\section{Education in-between Hope and Change}

Accordingly, there are definitely pedagogical challenges to be met in today's schools. In this digital era, one task is to support children as they develop an understanding of the complex world of today and to prepare them for a rather uncertain world of tomorrow (Halverson \& Shapiro, 2012). Prensky (2012) discusses how teachers in this century may ask themselves, how to teach today's students, what these students need and how it can be provided, etcetera.

Different educational stakeholders have emphasized that, as we respond to these challenges, digital technologies will substantially influence and improve teaching and learning in primary and secondary schools (for example, see OECD, 2009a; The Swedish National Education Agency, 2009a, 2013, European Commission, 2008; United Nations Development Programme, 2007). Governments - neoliberal, neoconservative and others - have continuously placed new ICTs at the core of both economic and educational policy, consistently arguing that as we move into the 21st century, economic, political and social processes will become increasingly knowledge and information based (Apple et al., 2005). ICTs have thereby been constructed as key to the development and marketization of education internationally and central to debates about curriculum across all levels (Kell, 2005).

Introducing a different technology into the classroom will always achieve an objective of bringing about change. That is, the introduction of technology in one area always affects other areas as well and it is hard to foresee what those effects will be (Heidegger, 1977a, 1977b; 
Fenwick \& Edwards, 2010). The problem, which is related to the techno-enthusiastic perspective pointed to, is that technology is treated as a black box, which hides all the work - social processes, technological histories, power plays, and beliefs that shaped it. This black boxing is reflected in the fact that technology in this way becomes a neutral tool for the development and facilitation of teaching objectives and goals by educational administrators, politicians, and techno-enthusiasts (Lee, 2009). Reasoning such as, for example, that 'schools must have computers or the nation will fall behind' or 'education and pedagogy will be renewed through computers and multimedia' has thereby often been the rationale for introducing technology in schools. The assumption that the introduction of technology would change and automatically lead to better education, however, is far from established (Cuban, 1986, 2001). Another view expressed by politicians and technology experts in discussions about introducing educational technology is that technology is just a tool to be shaped by the teachers - that is, 'we have given you the tools and now it's up to you to decide how to use them.' This speaks of a social deterministic account of technology. In this case, this social deterministic view often complements the technological determinism in education, which is a paradox in itself. These two inconsistent standpoints can have devastating consequences as technologies can be seen as both unavoidable investments and as mere tools that teachers are expected to adopt quickly, integrating them into their educational practice without having time to reflect on the possible effects (Lee, 2009).

Hence, there seems to be a need to unpack a potential discrepancy between the overall policy, the hope for change in school driven by digital technologies, and the 'real' state of technology use in teaching and learning (Cuban, 1986; Nissen, et al. 2002; Olofsson et al., 2011). Applegate et al. (1990) have already pointed out that ICT, when introduced in new settings, often dramatically changes the way people work. Streams of new practices are created, and it is useful to describe what these practices are (Gill \& Hicks, 2006). This makes it important to investigate in detail what happens when technology is introduced in schools. Engeström tells us that 'the multiplicity of change mecha- 
nisms is in itself a challenge to both practitioners and re-searchers' (2008, p. 380).

\section{Challenges for Educational Practice}

One point above is a presumption that technology, nowadays, seems to produce and give access to 'too much' information. In turn, the conditions in society change. Society becomes more complex and adds to what is expected from humans in relation to the available information and also other things. One challenge becomes to support students in learning to understand the complexities of today's world, where new methods and technologies are developed in order to cope with the information overload. The shift from books and texts towards screens and visualization technology can change not only the ways in which the world is presented but also the possible views of the world. There are probably potential benefits in this, but there are also difficulties and risks. The prevailing assumptions, that educational institutions need only adopt digital technologies in order to cope with the situation - and that teachers, if only they had the appropriate technology, can readily address the associated teaching and learning challenges - are rather simplistic. It should be kept in mind that making changes in education is not a linear process; rather it entails a number of discrete activities that affect and converge upon the system (Fenwick \& Edwards, 2010).

So, a rather intricate situation arises for education in schools due to these aspects and many others. Several theoretical issues and research questions emerge in relation to education which requires educators to sort and filter vast volumes of information in order to offer 'relevant information' about society and support students' analyses and knowledge formation. They emerge in relation to a society that expects more from its students in terms of how they develop and manage different kinds of knowledge, and that expects schools to cope with these new demands. They appear also as students confront a situation where they must develop their abilities and readiness to find their place in a society that is more intricate and complex than before. They arise in connection with the shift in handling and communicating information that not only changes the ways of describing the world, but also the ways of learning about and understanding it. As ICTs are 
often introduced in educational settings to support this new situation, also with the hope of changing and developing the educational practice, questions also arise about the direction in which ICTs, especially information visualization technology, change the work in classrooms and the circumstances for learning. When teaching and learning about the world, in social science classes and also in other subjects, the teachers and students seem to face puzzling circumstances. Students are often asked to consider multifaceted and compound socio-scientific issues ${ }^{3}$ in order to develop their picture of the world. Accordingly, it becomes essential to find out what conditions are actually emerging in social science education if new visualization technology is introduced in such school practices. A key approach would be to investigate the activities that take place when teachers try out such a technology, identify didactic concerns related to it, and then begin to use it in their classrooms. It also becomes significant to explore what happens when students use and interact with information visualization technology. It is central as well to discover how visualization technology and other matters shape the circumstances for learning in educational settings where this kind of technology is put into action. This may help to understand the learning conditions where visualization technology is employed, and may also develop awareness of potential challenges and/or opportunities for educational change.

\section{Visual Storytelling and Geovisual Analytics}

In this study a novel technology for visual storytelling is introduced in primary school social science classes and adjusted for use in this setting. This kind of technology is being developed within the research field of geovisual analytics (GVA). It is a 'young' interdisciplinary field, which integrates perspectives from geographic information science (building on work in geovisualization, geospatial semantics and knowledge management, geo-computation, and spatial analysis) visual analytics (grounded in information and scientific visualisation),

\footnotetext{
${ }^{3}$ A socio-scientific issue is usually considered to be one which has a basis in science and can potentially have an impact on society. Such issues can have an impact on individuals and groups at different levels, from determining policy through to individual decision-making and citizenship (Sadler, 2009).
} 
and cognitive, perceptual science as well as statistical data transformation (Tomaszewski, et al., 2007). The research field develops technology that attempts to visualize information and reinforce analytical reasoning, argumentation and knowledge building (Keim et al., 2006; 2008; Tomaszewski, 2008). The purpose of these tools, which also fall under the umbrella term 'geovisual analytics' (the same term that names the research field), is to allow critical scrutiny of facts and circumstances, allowing users to gain insight and to develop knowledge (Andrienko et al., 2010). This study is a part of this field, but since it is in the context of educational practice, the research questions go beyond what is normally studied in the field of GVA.

Visual storytelling within GVA entails methods that are supposed to help in sorting, filtering and analysing large volumes of information or data sets to convey messages. This is done in processes that combine automatic and visual analysis methods with interactions between humans and information. The Organisation for Economic Cooperation and Development (OECD) for example, has undertaken a wide range of activities aimed at improving the understanding of the opportunities of these tools which have led to increased interest for global and regional statistics ${ }^{4}$ (Jern, Thygesen, Brezzi, 2009). In this setting, GVA provides tools to help people to better understand the significance of statistical data by placing them in a visual context. Patterns, trends and correlations that might go undetected in text-based documents may be exposed and recognized easier with GVA tools.

For an analyst (in this case a teacher or a student, but in other cases the analyst could be an expert at, for instance, within the banking system or the public sector) who deals with information, the major challenge is not only to draw conclusions from the information, but also to present the results of the visual exploration process (Lundblad, 2013).

\footnotetext{
4 OECD's databases are e.g. connected, through direct import of data, to the technology used within this study. Links to these databases (OECD eXplorer and Factbook eXplorer) are: http://www.oecd.org/publications/factbook/ http://www.oecd.org/gov/regional-policy/regionalstatisticsandindicators.htm http://ncva.itn.liu.se/great-statistics-visualization/oecd-visualization?l=en
} 
Such presentation of the results also includes requests to share them more widely. In the context of GVA the process is divided as follows:

- Production is defined as the creation of materials that summarize the results of an analytical effort.

- Presentation is the packaging of those materials in a way that helps an audience understand the analytical results in a context, using terms that are meaningful to them.

- Dissemination is the process of sharing the presentation with the intended audience (Thomas \& Cook, 2005, p.137).

The specific technology ${ }^{5}$ used in this study, with its visual storytelling methods, was chosen because it is designed to aid in the process of gaining knowledge out of vast amounts of information - information needed when investigating for example social science issues. This is a question that relates to both society at large and education (Lundblad, 2013; Spence, 2005). The information that becomes available through this technology is in the form of official statistics. ${ }^{6}$ Gärdenfors (2001) argues that the ability to interpret statistics is underestimated in current educational curricula. He also says, 'for information to become knowledge it must be assessed, interpreted, and put into a context' (p. 55). The visual storytelling methods introduced in this study aim to support that, which means that:

- the technology builds around methods for data download, production of visual stories, presentation and publishing,

- a teacher may select and download statistical data from official databases in relation to educational goals,

\footnotetext{
${ }^{5}$ The Statistics eXplorer is the specific platform that is used in this study, see chapter 'The Application for Visual Storytelling,' for more information.

${ }^{6}$ Official statistics are statistics gathered at different geographical levels and published by government agencies or other public bodies such as international organizations. To have common criteria and conditions for official statistics among different countries in the world, in 1994 the United Nations Statistical Commission adopted 10 fundamental principles of official statistics (UNSD., 2007).
} 
- a teacher may use different ways to explore the data and interactive features to organize and design the chosen information,

- a teacher may create and produce educational material visualized stories - by using visuals to a great extent, but also text,

- a produced visual story can be presented and disseminated for possible use at blog or a web page,

- when a visual story is published on a blog or a web page, it becomes a Vislet, a (short visualized story as a booklet),

- a Vislet may be used as educational material on any computer e.g. by students in a social science class (Lundblad, 2013).

Rosling (2007) and Jern (2010) suggest that visualization in moving graphics is an intuitive method for understanding relationships and it is an effective way of exhibiting patterns. In the following chapter, visual storytelling is situated in relation to social science education, while the chapter 'The Application for Visual Storytelling' describes the specific application that is introduced and used in this study, which, as this is a comprehensive thesis, is also more thoroughly presented in papers I and II.

\section{Shaping Technology and Education}

To be able to critically discuss the introduction of a novel technology, it is necessary to first understand how technologies are woven into education at every juncture (Lee, 2009). In this effort it helps to move away from the understanding of technology in education that was earlier discussed as either a necessary condition for change and development or as a modernizing tool that can easily be employed in education on an impulse from a politician, administrator, researcher or educator. It is important to acknowledge that the concept of change in education is complex and multidimensional (Olofsson et al., 2011). It is also important to apply an inclusive perspective when trying to understand the interlocking relations between information, technology and education, processes of change and emerging learning conditions (Erstad, 2011). 
A way to start dealing with these issues is to turn to assumptions corresponding to a social construction of reality (Berger \& Luckmann 1967; Burr, 2003; Pinch \& Bijker, 1987). For my study, the socio-cultural view of human action shows that technology is a product shaped by social interest, struggles and politics. Learning and knowledge are, in this perspective, seen as embedded in tools, technology, in software and machines, etc. (Säljö, 2005, 2010a; Harasim, 2012; Wertsch, 1985). This counteracts a technological deterministic understanding of technology in education. I consequently view the shape and functionality of educational technologies as neither given by nature nor neutrally technical. I view visualization technologies used in education, like all technologies, as being shaped by the circumstances of their creation. This approach, according to some critics, may instead lead to social determinism, where the social determines the outcome of technical developments and completely removes the unpredictability of technology (Latour, 2005).

Discontent with the socio-cultural view of human action has led to other approaches that emphasize the heterogeneous nature of the forces that shape technology and accentuate learning as an emergent property of involvement in social and material practices. The most well-known perspective is perhaps the actor network theory (ANT) (Latour, 1987; Callon, 1986; Law, 1987). ANT attempts to trace how actors (both social and material) are bound together in a network of material and semiotic things. The advantage of this approach in relation to social and technological determinism is that it attempts to deal with social determinism by reintroducing the shaping powers of materiality and technology, but without submitting to the technologically deterministic view of technology as an external force (Lee, 2009). This makes educational technology not only a matter of the influence of social groups and their interests, but also contingent on a network of other factors such as materiality (Pinch \& Bijker, 1987). Sørensen (2009) demonstrates in her analyses of educational practices how attention to multiple spatial formations can lead to a rethinking of these practices and argues for the importance of taking both social and material actors into account in order to understand different forms of knowledge, presence and learning. So, the present study is informed both by socio-cultural views and ANT approaches. These theories 
shape my perspectives, research questions and understandings. They also provide me with two insights into technology in education. First of all, that educational technology is socially established. The other insight is that the material and technological aspects of constructing and using technology should not be disregarded, as they are decisive for how educational technology, education and learning are organized and shaped. Hence, it can be assumed that the introduction of a new technology may affect the learning activities and create new learning conditions. My viewpoint is that technologies on their own are neither good nor bad; it depends on how they are shaped and used; how humans and technologies manage to interact and under what conditions that interaction takes place.

\section{Aim}

The aim of this study is to understand how technology for visual storytelling can be shaped and used in relation to social science education in primary school, and also how social dimensions, technical and other matters create emerging learning conditions in such educational settings. As a result, more specifically, I ask the following research questions:

1. How can visual storytelling technology be shaped and used in ways that are relevant for social science teachers?

2. How can Vislets, as a specific type of visual educational material, be usable for primary school students in their social science education?

3. How are learning conditions constructed in social science education when visual storytelling methods are employed?

Following the insights related to socio-cultural views and ANT approaches, these questions are investigated in relation to social action and social context, and also to how material matters form activities. As a consequence, I use two different approaches in the study of visual storytelling technology in education. A socio-cultural view of human action is applied in relation to the first two research questions as they 
focus on the social practices, and the analysis is therefore performed in relation to this. To correspond with the aim, the third research question requires a focus not only on social activities but also must take into account activities of technology and other matters. The analysis is accordingly informed by actor network theory, which pays attention to both social and material action. In approaching this complex set of issues I attempt to provide a space for reflection that builds on three empirical materials. The empirical materials are generated, in Swedish schools, to complement each other in order to fulfil the study's overall aim.

\section{Structure of the Text}

The presentation of this study is divided into two parts. Part A consists of seven chapters. In the first chapter, Introduction, I present points of departure, areas of focus, and the outline of the study. In the second chapter, by describing didactic approaches, students' information practices and the ability to construct meaning from visuals I am Situating Visual Storytelling in Social Science Education. In the third chapter The Application for Visual Storytelling used in this study are explained. The Theoretical Perspectives that guide this work are presented in the fourth chapter. There I suggest approaches for analysing the visual storytelling technology in relation to social action (teachers and students) as well as the construction of emerging learning conditions in relation to both social and material action in the social science classroom. I also present central concepts that are used in the study. In the fifth chapter, Methodology and Research Design, the set-up of the study is clarified. I explain how the empirical investigations relate to each other, and discuss the applied methods, including techniques of data gathering and analysis, ethical considerations, and methodological concerns. A Summary of Papers is offered in the sixth chapter. Finally, the chapter entitled Discussion addresses a selection of themes in relation to the overarching aim and the results of the study.

The work concerning the different papers has been ongoing from 2010 through 2014. The composition of the study includes conference proceedings as well as articles. The inclusion of conference pro- 
ceedings can be seen as a result of a close collaboration with the National Centre for Visual Analytics (NCVA). ${ }^{7}$ That is, the technology used in this study has continuously been improved during the work, which has successively required rapid publishing. The papers included can be read as a more or less chronological story. Although paper I was published after paper II, it is presented first with the intention of facilitating an overall understanding of the study. The papers are all included in part B.

I. Stenliden, L. \& Jern, M. (2011a). Visual Storytelling Applied to Educational World Statistics. EDULEARN 11 Proceedings, Depósito Legal: V-2332-2011.

II. Stenliden, L. \& Jern, M. (2010). Educating Official Statistics Using Geovisual Analytics Storytelling Methods. INTED2010 Proceedings, Depósito Legal: V-845-2010.

III. Stenliden, L. \& Jern, M (2012a). How Can We Study Learning with Geovisual Analytics Applied to Statistics? Future Internet, 2012, 4(1), 22-41.

IV. Stenliden, L. (2013a). Understanding education involving geovisual analytics. Journal of Information Technology Education: Research, 12, 283-300.

V. Stenliden, L. (2014). Learning Conditions in Education Supported by Geovisual analytics. Reviewed and submitted to Technology, Pedagogy and Education.

The author of this thesis is the first author of all the papers included in this study. Empirical results are also presented in Jern \& Stenliden, 2011; Stenliden \& Jern, 2011b; Stenliden \& Jern, 2012b; and Stenliden, 2013b.

\footnotetext{
${ }^{7}$ NCVA is a Swedish national resource established in 2008. NCVA helps to spread geovisual and visual analytics technology into industry and government agencies.
} 


\section{Situating Visual Storytelling in Social Science Education}

In this chapter visual storytelling is situated in the context of social science education with the help of earlier research. The study takes a broad stance on the school subjects associated with social science education - also named citizen education, social studies or civic education - and considers it an interdisciplinary subject discourse. The research selection is made to focus the aim and challenges of social science education and to put a special attention to problem solving, information searching and research about visual aids. The selected research focuses to some extent, but not only, on primary school, as this study has attention on students in this age group. The broader stance has been taken, as research about information practices in education outside the Scandinavian countries has more often focused on higher education than on primary or secondary education (Francke \& Gärdén, 2013). It is not possible to be fully comprehensive, but the section as a whole aims to further support the analysis of research results presented in the different papers and in this comprehensive part of the thesis. First, social science education and its specific information and learning practice are presented. Thereafter, visual and analytical reasoning are highlighted.

\section{Social Science Education}

Different views on the school subject social science often associate it with development of students' worldviews, civility and rules, and citizenship, and also development of study skills such as searching for and evaluating information, argumentation and critical thinking (Barrue \& Albe, 2011). This is in order to build students' own argued opinions and participation in public debates (ibid). This last view is congruent with the critical emancipatory citizenship education generally promoted by research related to socio-scientific issues ${ }^{8}$ (Lauder et al., 2006; Sadler, 2009). This study is conducted in social science classrooms, where the students often work with these kinds of socio-

\footnotetext{
${ }^{8}$ For definition, see footnote on page 7.
} 
scientific issues. These usually concern both national and global problems, ${ }^{9}$ with the overarching aim of developing well-informed citizens.

\section{The aims and challenges of the school subject}

Students have particular views of the world which the classroom teacher and the school community should clarify, examine and question (Warwick et al., 2012). Social science education is the school subject where this takes place. The subject has a special place among other school subjects as it constitutes the society's communication channel into the school (Bjessmo, 1990). Bronäs and Selander (2002) argue that social science education should offer knowledge about how a society talks about and reflects upon itself (p. 75). The aim, at least in a Nordic context, is to develop students' competences of reflection on interdisciplinarity and self-reflection-as-citizen as these kinds of competences are seen as key tools for analysing societal problems and acting democratically on them (Larsson, 2012, Spanget Christensen, 2013). One argument is that problems and issues in global space are complex and can only be understood interdisciplinarily. Another argument is that the capacity for self-reflection is necessary for citizens (the students) in order to understand, maintain and develop their own (democratic) identity and (democratic) values and practices (Spanget Christensen, 2013). Barrett (2003) offers a comprehensive research review of children's understanding of nations and states as well as their beliefs and feelings about the people who belong to different national groups. He describes how globalization is having an enormous impact on children and that it is important to understand how children come to hold the national loyalties, affiliations and attitudes that they do. Reynolds and Vinterek (2013) explain how classrooms are increasingly becoming places of questioning values and attitudes as well as places where important community tools for democratic practice and international cohesion are applied. Main dilemmas according to e.g. Solhaug (2013) include:

\footnotetext{
${ }^{9}$ Global problems manifest themselves in at least three categories: 1) problems residing in the supraterritorial sphere (true global problems), 2) import of global problems into a national context, and 3) global consequences of acts taking place in a national context. Especially in the last two categories, the national citizen is mixed with the global citizen (Spanget Christensen, 2013).
} 


\section{Visual Storytelling Interacting in School \\ Part A: Situating Visual Storytelling in Social Science Education}

- the question of how to present information by adopting a national versus a global perspective,

- the challenges of teaching topics such as questions of multiculturalism to students of varying levels of maturity.

The importance of civic knowledge and participation has led to discussions on what actually promotes knowledge, participation and responsible citizens and what should be learned in social science education (Dalton, 2000; Hahn, 2010; Hedtke et al., 2008). In a study of social science education, teachers and principals emphasize 'knowledge' as the most important goal while 'critical thinking' is seen as the second most important (Schulz et al., 2010). In the Scandinavian countries, critical thinking was regarded as the most important goal (ibid.). These findings indicate that the teachers seem to value student participation and the formation of opinions in school rather than students being passive recipients of factual knowledge. The latter approach is also criticized by students for its meaninglessness and irrelevance (Solhaug, 2013). Therefore, students would benefit from wrestling with concepts and issues which are authentic and to some extent relevant to their lives (Spanget Christensen, 2013). This presents a predicament for teachers, in which they must attempt to balance facts, debates and practices in their conduct of social science education (ibid.).

\section{Domain-specific information}

There are few studies concerning what the actual practices in the social science classroom look like (Johnsson Harrie, 2011; Olsson, 2011). Sandahl (2013) argues that in order to understand what is going on in social science classrooms we need to interpret social science education in terms of first-and second-order concepts. He aligns with Husbands et al. (2003) and explains that first-order concepts are those related to a certain knowledge domain, and second-order concepts are more general in character and useful in other contexts as well (e.g. continuitychange). These two levels are constituted by terms and concepts that students need in their vocabulary to be linguistically competent in society. In addition, Spanget Christensen (2013) argues that social science education must be interdisciplinary and this includes self- 
reflection upon citizenship. To fulfil this requirement, a third-order concept is needed. These concepts are used to capture the need for a meta-perspective that meets the citizens/students in global spaces and connects to existing didactic practices and concepts (ibid).

Furthermore, in a subject didactic perspective, concepts, or domainspecific information and knowledge, become a sort of 'raw material' for decisions about teaching (Sandahl, 2013). Sandahl (2013) explains how the 'raw material' has to be transformed, shaped and constructed to offer information/content that suits the teaching situation and the current student group. Also, the pedagogical and methodological advice depends on the 'raw material' and influences the teacher's choice of actions. Hence, even the choice of work model depends on the content of the educational situation and goals for the lesson. Ongstad (2006) has introduced the Norwegian concept 'omstilling' (transposition) to explain this 'transposition' of the 'raw material' to concrete teaching material and actions. He argues that qualified teachers do this 'transposition' of the domain-specific knowledge continually. It is plausible to see teachers' ability to transpose their didactic knowledge of their subject as central to their classroom teaching competence (Sandahl, 2011). Kjällander (2011) argues that teachers have an exclusive role in designing the subject area where the didactic design is usually aligned to curriculum and course criteria, and students are also made aware of the frames of the didactic design.

Kjällander explains, though, how teachers are often absent during the students information searches and their translation process of the educational information (2011). Reynolds and Vinterek (2013) argue that students are not always being provided with a consistent and measured view of the world. It is not being done correctly visually nor perceptually by different kinds of information resources. Therefore, they argue that social science education may adapt new practices at the classroom level and adjust the practices to new requirements associated with technology use and awareness (Reynolds \& Vinterek, 2013). Also, Kjällander (2011) argues for changing existing subject practices and suggests that social science education could be more strictly framed. 


\section{Completing problem solving assignments}

The practice of completing problem solving assignments in social science education is central. Problem solving is in PISA 2012, defined as: 'an individual's capacity to engage in cognitive processing to understand and resolve problem situations where a method of solution is not immediately obvious. It includes the willingness to engage with such situations in order to achieve one's potential as a constructive and reflective citizen (OECD, 2014, p. 12). The students are expected to work with solving problems by searching for and translating information into knowledge, and also by putting the information into new products (formulating texts, creating posters, preparing digital presentations, etc.) (Gärdén, 2010; Kjällander, 2011). The activities involved in these kinds of assignments have in Sweden, since the 1990s, been dominated by a student-centred mode of operation (Francke \& Gärdén, 2013; Swedish Educational Agency, 2009b) and according to Vinterek (2006), this approach is often un-problematized both in government documents and in classrooms. Francke and Gärdén argue that this practice matters to students and shapes how the students search for and treat information (2013). Usually the students' activities in this kind of practice start with various kinds of information searches that include technology (Alexandersson \& Limberg, 2003). School documents and vision plans also currently describe the ability to use technology in such activities as a core competence that relates not only to schoolwork but also to life in general (Alexandersson \& Limberg, 2012; Alexandersson et al., 2007; Francke et al., 2011; OECD, 2009a, b; Ravenscroft, 2012; Schleicher, 2011; Swedish Educational Agency, 2009a, b; Sundin et al., 2011; Tuominen et al., 2005).

Likewise, several studies show how the development of information strategies or knowledge of how to treat information is always linked to students' understandings of the school assignment in general, which in turn forms the ways they use information (Boström, 2011; Francke \& Gärdén, 2013; Gärdén, 2010). The students often implicitly try to understand what is required (Osberg \& Biesta, 2008), and their achievement depends on what they believe their school tasks entail (Bergqvist, 2001; Carlgren, 1997). Lantz-Andersson (2009) explains how children become accustomed to 'doing school' through their own 
experiences, and through extensive socialization they also learn how tasks are normally organized, valued and marked. An argument made by Krange and Ludvigsen (2008) is that 'it is only knowledge that is strictly necessary to solve the problem that is given attention' (p. 45) and the students' primary concern are simply to complete the given task, with or without gaining knowledge (ibid.).

\section{Search strategies}

Nowadays, students' information searches are usually done using the Internet, and the results typically come in different forms of potentially multimodal documents (Kress, 2010), even though text is still the dominant mode at school (Francke \& Gärdén, 2013). When using the Internet, students and teachers alike often have problems finding relevant written material suitable for the younger students. These students also seem to need a lot of support during their searches. In addition, research shows that teachers in many cases underestimate the trouble students have during information searches (Alexandersson \& Limberg, 2012; Alexandersson et al., 2007; Gärdén, 2010; Jedeskog, 2001; Limberg, 2005; Limberg et al., 2008; Lundh \& Limberg, 2008).

Moreover, it is evident that the procedures of copying facts from books and web pages often come into focus as strategies for students' information search (Limberg, 2005). Limberg (2005) also shows that this conception of an information search among students - as factfinding - often correlates with poor learning outcomes. Lundh and Limberg (2008) also show this in their study in an elementary school. When the students, while doing their assignments, used ICT tools to search, find and analyse information, the starting point was often to find a printed source (a book) and/or search the web through Google. Kjällander (2011) claims that when primary students search for information on the Internet, their learning path, almost without exception, begins at the search engine Google. This common approach today is expressed by Auletta: 'We don't search for information, we Google it' (Auletta, 2009, p. xi).

Another aspect of students' search strategies is that they frequently navigate via the multimodal options displayed on the screen, and the 
students' activities are often selection-driven (Adami \& Kress, 2010). This means that young students are often clicking rather randomly on various links they come across that they appreciate as salient (van Leeuwen, 2005, 2006). In other words, the image or text attracts their attention, and thus they choose to engage with it. Things a student might regard as salient include images of people, words in their mother tongue, images that they recognize from previous encounters, images that they regard as 'cool' and texts that are presented as exciting or provocative (Kjällander, 2011). This manner of searching often results in students changing the aims of their work and negotiating the object of knowledge in order to incorporate salient texts or images into their assignments. Kjällander (2011) shows how learning activities in a student-centred mode in social science classrooms constantly change direction, due, for example, to an attractive image on the screen.

Furthermore, Google's option to search for images instead of words is often used by younger students (Kjällander, 2011; Lundh, 2011). This happens a lot if the students are unsure of what a word means as the image seems to reinforce their understanding (Kress, 2010). This is in line with, for example, Price and Rogers (2004) and Alexandersson (2002), who claims that visualizations can 'gestalt' information and make abstract concepts concrete in more varied ways than other resources can. They can hold some of the richest possibilities for learning (Chen, 2006; Kress \& van Leeuwen, 2006; Lindgren, 2005; Lindgren \& Nordström, 2009; Tufte, 1983).

\section{Different ways to interact with information}

So, students, images and texts nowadays interact in more complex ways than they did in the past, and as shown, on the screen or the multimodal page there is no strict adherence to reading from left to right as with linear texts. As Kress $(2003,2010)$ argue, what we see emerging is the practice of 'reading as design' you select and attend to what is presented in a manner that is steered by your own perspectives and interests. What he emphasizes is that we are moving away from reading as interpretation towards reading as a matter of imposing order and relevance on what is presented. This is what the presentation of information strategies and practices when solving social science 
problems have shown; the students select and attend to what is presented in a manner that in many ways is steered by their own perspectives and interests (Kjällander, 2011). Van Leeuwen (2006) argues that this is a mode where semiotic resources such as composition, movement and colour, including images, graphics, typography, etc., create an integrated multimodal approach to visual communication. Both Mäkitalo et al. (2009) and Säljö 2010a) discuss this and what happens if/when teachers (and students) shift from using traditional (static) texts to use interactive and collaborative once. They argue it is our ability to make insightful and productive use of the collective resources in locally relevant ways that is of interest.

\section{Visual and Analytical Reasoning}

In discussions about understanding and knowledge, terms grounded in human visual experiences in the surrounding world are often used: to see/to understand; open your eyes or catch new sight of (Lindgren, 2005; Lindgren \& Nordström, 2009; Sparrman \& Lindgren, 2010, Tufte, 1983). The vocabulary indicates that seeing, and the ability to see, has significance for understanding and aids analytical reasoning (Keim et al., 2008; Tufte, 1983). Tomaszewski \& MacEachren (2012) among others, argue that this ability should be taken advantage of more frequently and systematically by using visual analytic tools.

So far, however, little attention has been directed to issues about the use of geovisual analytics tools within school environments (Lundblad \& Jern, 2012; Nicholson et al., 2011). The geovisual analytics tools are probably neither very well known to practitioners in schools nor is there much knowledge about the outcomes of their use in educational settings. Otherwise research about learning and educational technology represents a huge field, both internationally and in Sweden (Cuban, 1986, 2002, Erstad, 2011; Goolsbee \& Guryan, 2002; Kjällander, 2011; OECD, 2009b; Olofsson et al., 2011).

Several studies have indicated that the use of visual aids greatly improves information retention and expands students' understanding of unfamiliar concepts (Butcher, 2006; Mayer \& Moreno, 1998; Nesbit \& Adescope, 2006; Robinson \& Kiewra, 1995). Unlike texts, images 
have immediacy - they can convey a great deal of information quickly and concisely. The ability to construct meaning from visuals also becomes more and more relevant (Avgerinou \& Pettersson, 2011; Metros, 2008; Nesbit \& Adescope, 2006). Lapp et al. (1999) stress the importance of active reading based on data visualization and the importance of visual communication to capture attention, reinforce knowledge and increase audience responses. They use the term 'intermediality' to describe the combined literacies needed in these kinds of activities. This competence is usually defined as visual literacy (Giorgis et al., 1999). This study aligns to Bamford (2003) and Avgerinou et al. (Avgerinou \& Ericson, 1997; Avgerinou \& Pettersson, 2011), who define visual literacy as the ability to construct meaning from visual images in a way that involves interpreting images of the present and past and the ability to produce images that effectively communicate the message to an audience.

Furthermore, a number of studies under the umbrella of social science education have shown the importance of visuals. This is in relation to students' analytical reasoning and the development of their worldviews and their understanding of people's living conditions and circumstances (e.g. Kinzel \& Wright, 2008; Plester et al., 2006; Reynolds \& Vinterek, 2013; Wiegand, 2003). Plester et al. (2006) explain that visual representations such as maps, diagrams and images (e.g. photos and films) are particularly important sources of knowledge about environments. According to Reynolds and Vinterek (2013), teachers and the school community are quite unaware of this significance. These researchers claim there is an imperative to address the value of visuals such as maps, diagrams, scatter plots, etc. to support young citizens to become fair-minded global citizens (see figure 1).

Increasingly, maps are interactive, so that the user can select required layers of information, access spatial databases to search for and then customize data, alter the way that data are represented on the map and use various tools to analyse them (Wiegand, 2006). Such powerful combinations of software, hardware and data are called geographic information systems (GIS). These data visualization tools go beyond the standard charts and graphs used in, for example, Excel by 
interacting with the data in more sophisticated ways such as geographic maps, multidimensional bubble plots, fish eye bar charts, table lens, scatter matrix, parallel coordinates, distribution plot etc (see figure 1). These visualization tools include interactive capabilities, enabling students to manipulate them and drill into the data for querying and analysis.

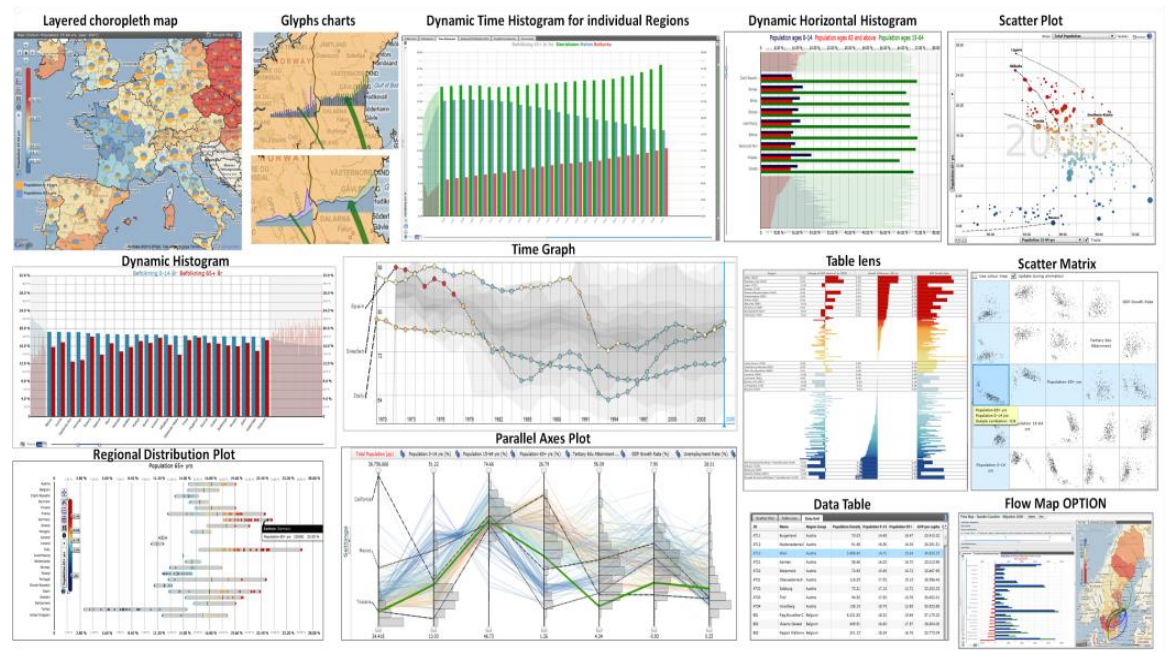

Figure 1, Data visualization - toolkit and interactive features, represented by layered choropleth map, composite time-linked histogram, time graph, scatter plot view, parallel axes plot, etc.

Wiegand (2003) shows in his study, insights into students' (aged 14-15 and 16-17) thinking with a GIS's choropleth mapping function. Participating students exhibited high levels of conversational exchange about mapping strategies and the geography revealed by the maps. These students did not appear to be daunted by using 'professional' software, although they did not exploit the full range of functions. The choropleth map data seemed to have 'directionality' to the students. However, some significant misconceptions were identified in the students' thinking. Darker areas that regularly mean 'better' or 'worse' depending on the variable being mapped often misled the students in what these different aspects could imply according to colour intensity. Students also tended to exaggerate or generalize when they described the data sets. Also, the students generally did not recognize the scale of the map. Instead, they referred to places on the map as 'there, near the 
coast' although the places were quite far away from the coast. Key areas for teacher intervention would appear to include promoting better student understanding of what the mapped data meant (including directionality and numerical characteristics) and effective strategies for raising the level of students' conceptual exchange during collaborative learning (ibid).

Kinzel and Wright (2008) examine the application of multimedia technologies and interactive geovisualization tools based on National Geography Standards in high school curricula in Canada to develop spatial thinking and to promote geographic literacy. They suggest that mapping tools such as Google Earth, GeoMapApp, AEJEE, ArcGIS and ArcExplorer have the potential to change the traditional earth science or geography curriculum and education. Further, they (Kinzel $\&$ Wright, 2008) argue that effective tools for teaching about these issues are interactive ones, such as GIS map projects, visualizations, computer models and computer animations that allow the learner to manipulate the environment and outcomes of the learning process. They assert that these types of tools allow for a high degree of active learning, a modality of teaching and interacting that places the emphasis on the student.

Wiegand (2006) argues that students' use of maps is a complex activity and makes a distinction between map reading, map analysis and map interpretation. In this view, map reading is characterized as simply extracting information from the map. Map analyses involve processing that information in order, for example, to describe patterns and relationships or to measure distances between places. Map interpretation goes beyond what is shown on the map and involves the application of previously acquired information in order to solve problems or make decisions.

In conclusion, the findings point to some significant pedagogical challenges, such as the complex issues of the world, the masses of available information, the information to be presented in adopting a national versus a global perspective, the practice of student-centred problem solving, teachers' absence from the transformation process of the educational information, students' 'googlified' search strategies, 
and critical source evaluation. What is encouraging, though, are some of the results that indicate positive aspects for the use of visual educational material and tools such as GIS in schools. ${ }^{10}$ Altogether, there seems to be potential for and appropriate tasks to support - the development of students' competences in analyses of visual data - the visual analytic process.

\section{Tools for visual analyses}

In the GVA field, a visual analytics process is described as an attempt to combine automatic and visual analysis methods with interaction between humans and data or information (Andrienko et al., 2007; Andrienko et al., 2011; Tomaszewski \& MacEachren, 2012). The idea is to take advantage of the thoughts that: ...computers are incredibly fast, accurate, and stupid. Human beings are incredibly slow, inaccurate, and brilliant. The marriage of the two is a force beyond calculation' (Cherne, 1982, p. 93).

In a visual exploration process the analyst (the student) and the visualization interact to reveal insight by trying to translate information into some sort of understanding (see figure 2) (Keim et al., 2010).

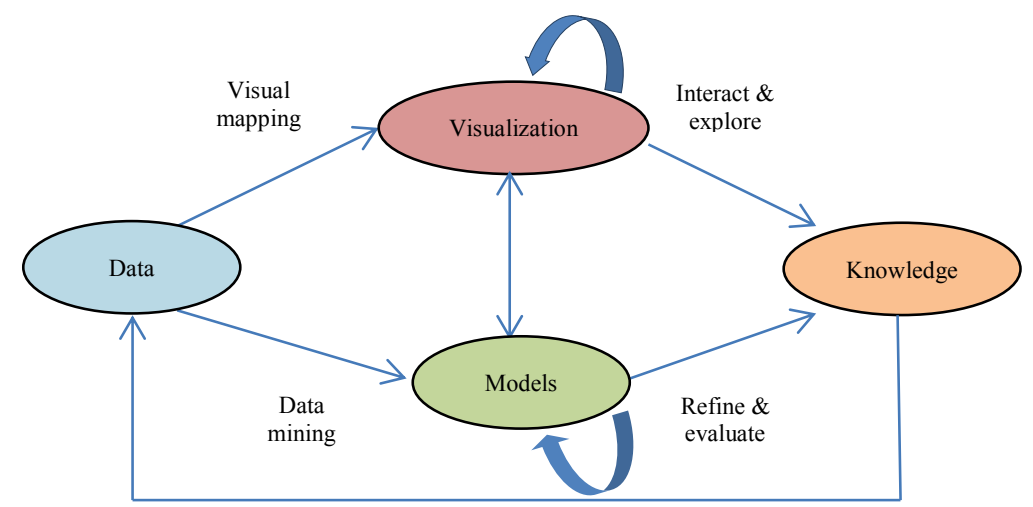

Figure 2, The dynamic visual analytics process combines automatic and visual analysis methods. Knowledge is gained through human interaction, with alternation between visual and automatic methods (D. Keim et al., 2008).

\footnotetext{
${ }^{10}$ A Swedish website for teachers about the use of GIS in schools: https://sites.google.com/site/gisiskolan/home
} 
Shneiderman and Plaisant (2005) have developed a well-known visual exploration guide which has also been extended by Andrienko et al. which then says: 'analyse first, show the important, zoom/filter, analyse further, details on demand' (2011, p. 10).

Evaluation studies in the field do not necessarily consider the underlying transactions that reflect problem solving or cognitive processes, which have historically been identified with knowledge discovery, complex decision making, and insight (Greitzer et al., 2011). However, a general result from research on advancement in the GVA field is that it would be facilitated by, as Greitzer et al. say, 'devoting more attention to cognitive foundations that will inform future research and evaluation approaches' (2011, p. 25). They suggest that the impact a data visualization tool has on insight, knowledge discovery and knowledge creation is a function of the extent to which the tool solutions enhance situation awareness (SA). Endsley $(1988,1995)$ and Endsley et al. (2004) explain situation awareness with reference to the highly recognized SA model that consists of three steps (see figure 3).

1. Perception of the elements in the environment

2. Comprehension of the current situation - get an understanding

3. Projection of future states - able to predict and make decisions

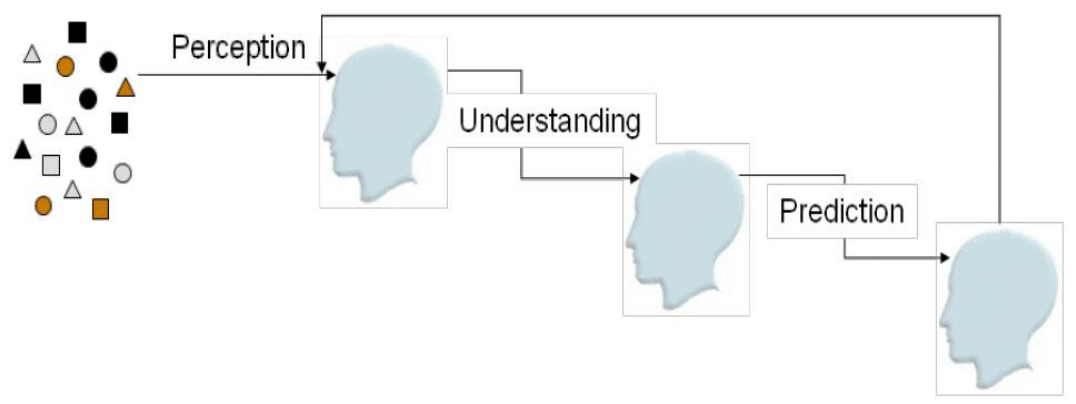

Figure 3, Situation awareness according to Endsley et al. (2004). ${ }^{11}$

\footnotetext{
${ }^{11}$ The graphic comes from a presentation by Greitzer et al. (2008) at IEEE Power \& Energy Society Annual Meeting.
} 
With this account, questions arise about the challenges, benefits and pitfalls teachers and students face when applying information technology, with the aim of supporting visual and analytical reasoning, for:

- finding information located in information sources,

- information retrieval and communication,

- controlling information,

- building up a personal knowledge base in a new area of interest,

- working with knowledge and personal perspectives adopted in such a way that novel insights are gained,

- using information wisely for the benefit of themselves and others (Bruce, 1997, 2000).

To conclude, in this section I have discussed the context of social science education to situate technology for visual analytical reasoning in relation to this school subject. I have described the practice of the school subject to reveal whether this kind of technology may have relevance and potential to help equip children for a world that increasingly depends on information, visuals and technology.

The next chapter aims to explain the specific technology for visual storytelling that is introduced in social science education in this study. 


\section{The Application for Visual Storytelling}

The technology for visual storytelling that are introduced by and in this study can be seen as methods to support teachers' 'transposition' of 'raw material/information' (Ongstad, 2006, p. 22) and students' 'visual analytical reasoning.' Andrienko et al. (2011) suggest that, to achieve this support and create opportunities for analysis and knowledge formation, an application should include methods for production, presentation and dissemination of a message/a story. This means a) methods to download data, transform the data into visuals, and explore the data, b) methods to create a story and include text, snapshots and interactive features that emphasize certain (visualized) content into the story, and c) methods to share the story with others. Translated to an educational context, this process can be explained as the teachers' processes of selecting and exploring information, didactically design the information in relation to the aim of their teaching and their students, and to make it possible for their students to easy access the presented educational material.

These methods for production, presentation and dissemination of a message/a story should all be well integrated within the same application (Lundblad, 2013). Therefore, the application chosen for use in this study is the Statistics eXplorer platform, which offers the methods needed (Jern, 2010, May; Ho et al., 2011, 2012).

\section{Production - Import Data, Explore and Gain Insight}

To start a visual storytelling process with the Statistics eXplorer platform, the analyst, in this case a teacher, who wants to create a teaching material, usually starts with an import of data from a databank with official statistics, such as the World DataBank (see figure 4). The selection is then based on content as it relates to the educational goals to be met. Official statistics can provide quantitative or qualitative information on major areas of citizens' lives, such as economic and social development, living conditions, health, education, and the environment. In most nations and societies today official statistics play a vital role in fields of human activity. In education, though, official 
statistics are probably much less recognized and used (Jern, 2010, April).

For the teacher it is possible to directly import the selected official statistics to the platform through integrated database interfaces. ${ }^{12}$ This is to facilitate the accessibility to the official statistics. Other statistics can be used as well, for example, those collected in a survey among the students. To proceed in the production phase, the teacher explores the selected data (the indicators chosen from the data base). The teacher discovers and gain insight in the official statistics, among indicators such as 'population growth', 'fresh water consumption', or 'energy production' and decides what content is going to be processed in the classrooms. The teacher can then orchestrate and display the data/ indicators by using the platform's storytelling functions (see figure 4).

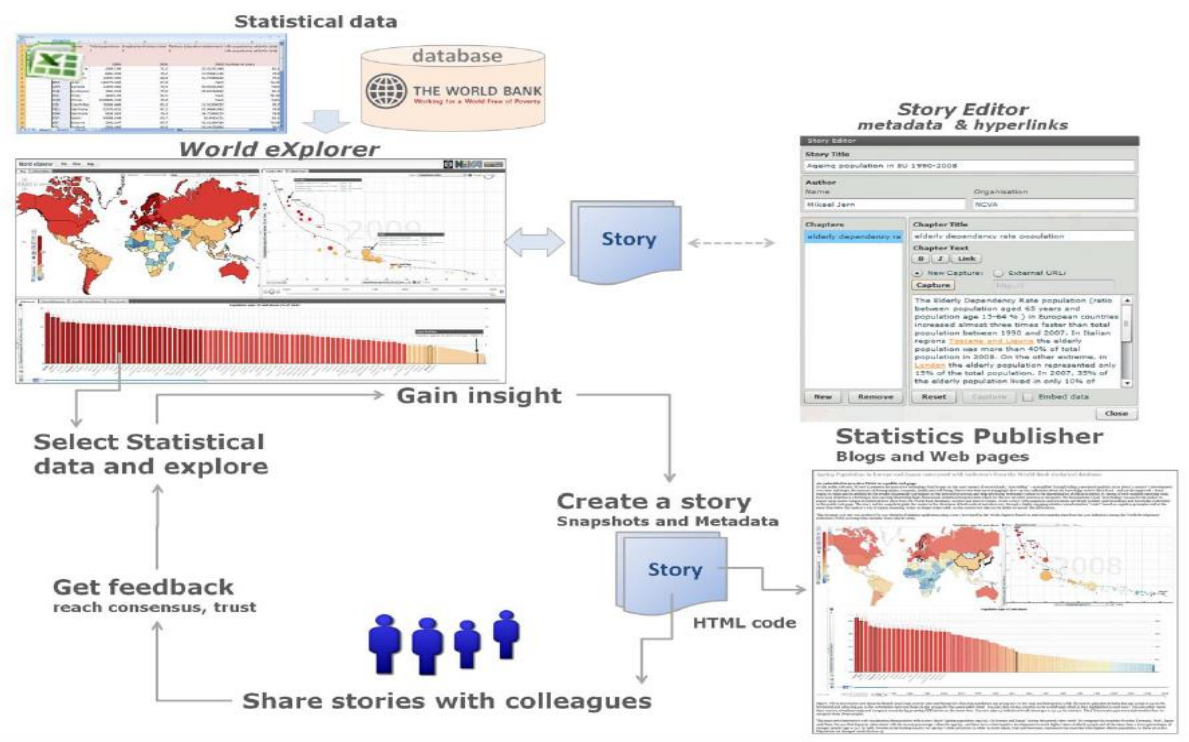

Figure 4, Production - import data, explore and gain insight in the information to create a visualized story.

\footnotetext{
${ }^{12}$ Links to integrated database interfaces:

http://ncva.itn.liu.se/explorer/world-explorer?l=en

http://mitweb.itn.liu.se/GAV/world/

http://ncva.itn.liu.se/explorer/storytelling?l=en
} 


\section{Presentation - Toolkit and Interactive Features}

At this stage, the teacher creates and prepares his/her own educational material and can display different interactive areas (see figure 5).

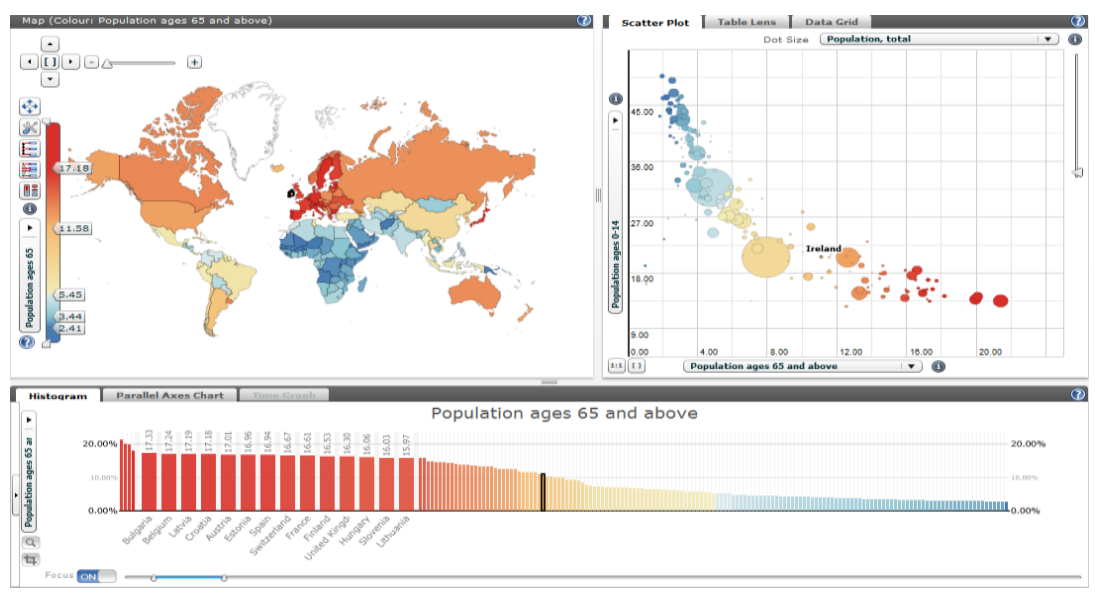

Figure 5, The teacher has here chosen a layered choropleth map, a scatter plot view and a histogram to organize and show the visual information.

Findings that the teacher makes during the discovery process can be documented with snapshots and associated descriptive meta text, and the snapshots can be accessed via hyperlinks (see figure 6) (Lundblad, 2013). The teacher can also attach external web links to relevant infor-

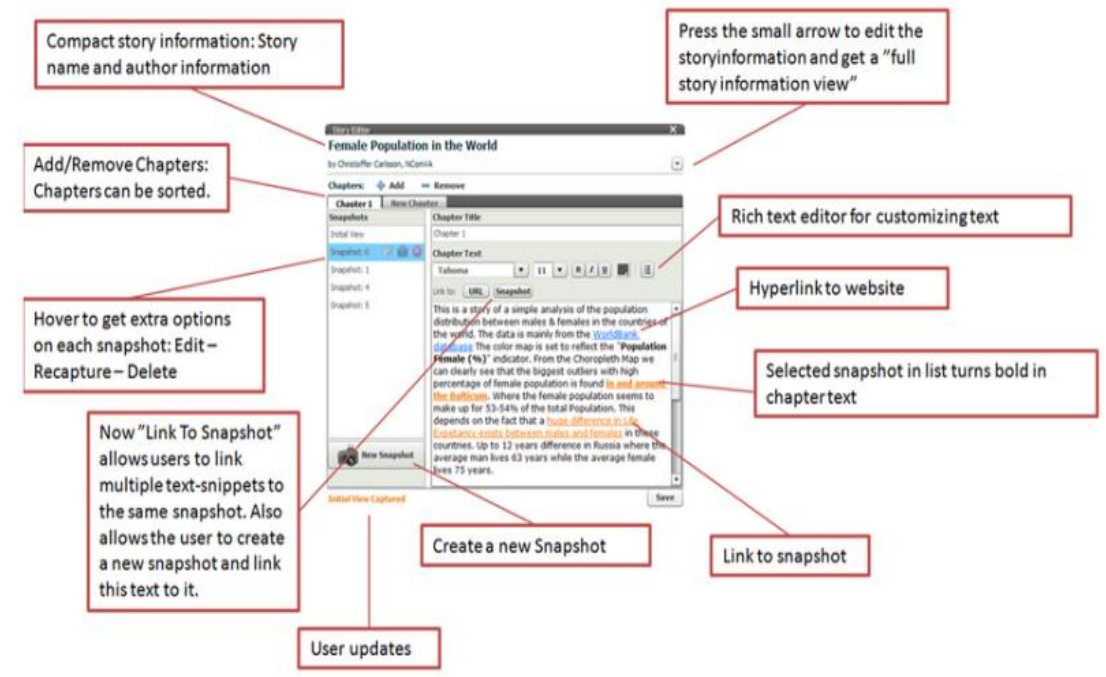

Figure 6, Presentation - text, snapshots and hypertext can be incorporated in the story. 
mation that can contribute to a more complete understanding of the lecture. The web addresses are transformed into hyperlinks as well.

\section{Dissemination - Publishing the Visual Story}

In order to publish the created story the teacher uses a publisher tool. This tool transforms the educational material into HTML code that can then, using the copy-and-paste function, be published on a blog or a web page (see figure 7).

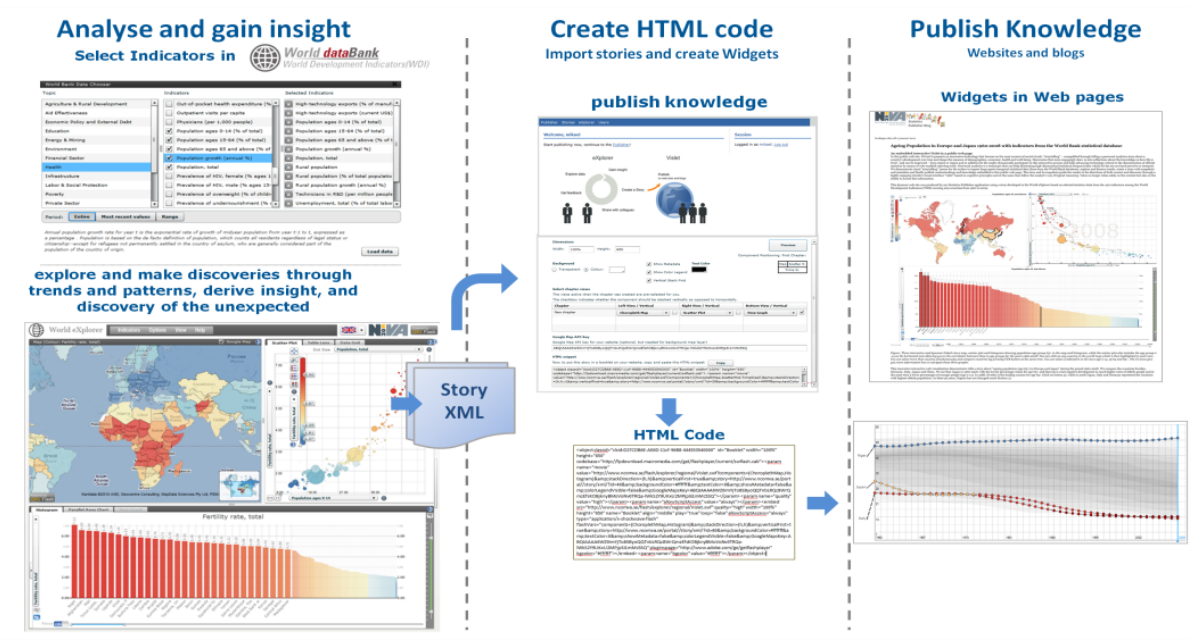

Figure 7, Dissemination - publishing the visual story, with help of the publisher tool.

\section{A Vislet - The Story on a Web or a Blog}

When the story is published on a web page or a blog, it becomes a Vislet. The Vislet is accessible from any computer with an Internet connection. The students can then interact, analyse and create knowledge in relation to the interactive educational material customized by the teacher. Visual storytelling is, in this scenario, an approach in which engaging stories can be shown and told to students through interactive web-enabled visualizations.

By this presentation of the application used in this study the intention is to move forward with the outline of the study. To be able to conduct the study theories are needed to guide the work. Therefore, the next section tries to clarify theoretical choices made in the study. 


\section{Theoretical Perspectives}

This chapter will explain the theoretical standpoints I take in this study. My stance is that it is essential to be critical to taken-for-granted ways of understanding the world. I see conceptions of what is understood as reality as historically and culturally relative and constantly negotiated. My vantage point is consequently assumptions corresponding to a social construction of reality (Berger \& Luckmann, 1967; Burr, 2003; Pinch \& Bijker, 1987). Also this study can be viewed as a social construction. Two theoretical perspectives are used to answer the research questions. A socio-cultural view of human action is applied to answer research questions one and two. In order to answer research question three, I need to take into account the agency of both humans and materiality. I therefore chose actor network theory (ANT) as I see it as attempting to approach both social and material action. These perspectives not only simultaneously offer both related and differing views to my analysis, they also inspire an analytical sensitivity to the associations between information, technology, education and learning. Due to the interdisciplinary character of the study, the study is partly affected by cognitivist theories (Broadbent, 1958; Piaget, 1970; Piaget, 1971), as differing theories and approaches dominate in different disciplines. In this chapter I explain theoretical concerns in relation to the study's interdisciplinary character and introduce the different theoretical approaches used in the study as well as discuss motives for applying them. Finally, I present some additional central concepts.

\section{Theoretical Aspects and Interdisciplinarity}

This study is positioned, as pointed to, within the research field of educational practice. It is also conducted in close collaboration with researchers in the field of GVA, and the study can be said to be a part of that field. ${ }^{13}$ The GVA field, like many other fields within media

${ }^{13}$ Some of the results from this study are published within visual analytics and geovisual analytics, i.e. paper III: Stenliden, L. \& Jern, M (2011). How can we study learning with geovisual analytics applied to statistics? Future Internet, 2012, 4(1), 22-41, which is published in a special issue on geovisual analytics. My partners at 
technology, builds partly on cognitive assumptions. ${ }^{14}$ Technology and its functions are most often constructed with these as starting points. In tests of technology developments cognitivist theories are commonly used and they are also frequently used when studying learning with ICT or multimedia learning environments (Ertmer \& Newby, 2013; Mayer, 1996, 2006; Mayer \& Moreno, 1998, 2002; Sweller, 1988; Sweller et al., 1998). So, as a researcher within educational practice, working with researchers in GVA and media technology, I draw on different theoretical perspectives. The study's first two research questions are partly influenced by research questions within GVA and media technology research. Throughout the work with those research questions I work closely with NCVA and the researchers there. These initial investigations concern the introduction and shape of the technology, and the technology's use in relation to teachers and students, which is a research task also for GVA. I believe this kind of collaboration adds value to this study, even though it is sometimes difficult to fully integrate arguments from other theoretical perspectives (Klein, 1990) such as, for example, when cognitive views at times encounter the theoretical positions I try to take in this study. On the other hand, it would not be possible to conduct the study without this collaboration.

The effect of the interdisciplinary character of the study may be most obvious when I explore research question two by conducting a usability study. Usability studies investigate whether it is possible to use the technology in relation to humans. Within the field of humancomputer interaction, 'usability' is a core term, and a set of usability heuristics (ISO 9241-11) 15 $^{15}$ is often used to estimate the technology's so-called usability in relation to humans. I find this to correlate to the

NCVA have also published results on data from this study i.e. Lundblad, P., \& Jern, M. (2012). Visual storytelling in education applied to spatial-temporal multivariate statistics data. In J. Dill, R. Earnshaw, D. Kasik, J. Vince \& P. C. Wong (Eds.), Expanding the frontiers of visual analytics and visualization (pp. 175-198). London: Springer.

14 For examples see citations of Card et al., (1999) on p. 3 and reference to Greitzer et al. (2011) on pp. 27.

15 ISO 9241, is a multi-part standard from the International Organization for Standardization (ISO) covering ergonomics of human-computer interaction, concerning ergonomic requirements for work with visual display terminals. 
investigation in focus. A lot of effort has been made to define the term 'usability' and to determine how to analyse/measure in these kinds of studies. 'Usability' has often been defined as 'quality in use' (Bevan, 1995). Some have defined it as 'the capability to be used by humans easily and effectively' (Shackel, 2009, p. 2), and there are different current practices in measuring usability (Hornbæk, 2006). Instead of applying cognitivist analyses, I try to extend the way of carrying through the usability study. My standpoint is that to investigate the usability of the technology that is introduced for students' use in primary school's social science education, it does not suffice to ask, for example, whether 'multiple-representational technology is an effective learning environment' (Ainsworth, 2008, p. 249). Instead, my stance is that more complex questions also need to be asked, such as: Under what circumstances, with which design factors, for which learners, performing which tasks and expecting what outcomes is learning with multiple-representational environments sufficient? I am therefore already applying a socio-cultural perspective in the early stage of the research process. ${ }^{16}$ Having addressed concerns about interdisciplinary and theoretical encounters, I move on to the two main approaches for analysis in this study.

\section{Two Theoretical Views}

As has now been made clear, the two different theoretical views that mainly influence this study and its analyses are the socio-cultural perspective and ANT. These theories share the same basic assumptions that knowledge is developed in practices and by action, as well as the view of how people establish their identities. Humans cannot be understood in isolation from the world they interact within - in the case of a socio-cultural perspective, from context (Lave \& Wenger, 1998), and in the case of an ANT perspective, from the networks (Law \& Hassard, 1999). So there are similarities, but the important difference is in how these perspectives conceive subject and object (Fenwick \& Edwards, 2010; Sørensen, 2009). I have used the variations in the theories to answer the study's overall aim and the different aspects in the research questions. The position I take is that

\footnotetext{
${ }^{16}$ The usability study and its results are outlined in paper II. The theoretical and methodological issues concerning this matter are thoroughly discussed in paper III.
} 
research questions one and two require an understanding in relation to social action and social context - a socio-cultural perspective. To be able to answer research question three, I take the position that it requires, in addition to social action, an understanding of how activities are formed in relation to material actors. The first choice: a socio-cultural perspective, grows out of a desire to investigate possibilities for human action in relation to the novel technology introduced in primary schools for teachers' use in their teaching practices and for students' use in their social science classes. The second choice, an ANT approach, stems from the interest in also exploring how the technology and other matters shape activities and have an impact in schools. This concern makes it necessary to take account of non-human actions as well. By this view the approach to action changes.

The remainder of this chapter discusses the chosen theories in relation to the study. First the socio-cultural view is deliberated upon. This account include Vygotskij (1978, 1986), Rogoff (1995) and Bruner (1974) as well as later theoreticians such as Driscoll (1993), Wertsch (1998), and Säljö (2005) among others. Thereafter, central thoughts on ANT are deliberated upon. These thoughts are discussed with reference to Latour (1987, 1992, 2005), Callon (1986), Callon et al. (1986), Law (1987, 2002) and Law and Hassard (1999) as well as others including Ashmore (1993), Hekman (2010) and Fenwick and Edwards (2010, 2012a). Finally, central concepts are clarified and their use in the study is explained, all in relation to the chosen theoretical perspectives.

\section{A Socio-cultural Perspective}

A socio-cultural perspective emphasizes that human action is situated in relation to societal and cultural contexts and that tools are carriers of knowledge and culture (Vygotskij, 1978; Wertsch, 1998). In this perspective, humans are seen as separate from objects, tools and artefacts. So what can be studied are the activities that take place in a certain context and how tools and resources are used. This means that the interactions between humans and humans' interactions with tools become significant. Central to this perspective is also the 
communication that takes place between humans. Also significant is how humans interpret the context as language and discourses are seen as constituting the world. With these assumptions it is possible for me to approach the first two research questions. They address teachers' and students' actions with the technology in relation to the school context - the teaching, the learning, the classrooms, etc.

\section{Human - action - context}

According to this view, human action and learning cannot be extracted from the context in which they occur (Lave \& Wenger, 1991). The situated-ness of humans is accentuated as is the importance for individuals of becoming part of a social group and acculturating into it. This is acknowledged as the process by which individuals come to understand, appropriate and appreciate the values, norms and practices of a group and become a part of that community, with all the implications that come with that (ibid.). So, as fundamental assumptions, with socio-cultural eyes I see action and learning as processes that can differ dependent on what community the human is associated with, as well as on available tools and resources (Lave \& Wenger, 1998; Säljö, 2005; Wertsch, 1998). As a result, the interactions that take place between humans (teachers and students) and the humans' interactions with tools are studied in the social context (the school setting/the social science classrooms).

\section{Interaction - tools - mediation}

Within this perspective another standpoint is that, as human action and learning are intertwined with, and dependent on, the surrounding culture, they are also dependent on how knowledge is shared (Vygotskij 1978, 1986; Rogoff, 1995). Knowledge can be shared through interaction with other humans or with the help of tools or artefacts. Via sets of tools that are available in the particular community where humans act, knowledge is seen as being mediated (Säljö, 2005; Säljö, 2010b; Wertsch, 1998). Therefore action and learning are not just dependent on individual knowledge or skills, or on the ability to collaborate, but are also distributed across available tools and the human capability to access and use them (Säljö, 2005). Consequently, the view I take in this study from this view point is that tools allow transmissions of knowledge that can be seen as cultural 
representations of the world (Säljö, 2005; Säljö, 2010a; Wertsch, 1998). Individual understandings are therefore seen as assisted from 'outside' the individual and the limits of development depend on how a culture can assist the individual to use his/her intellectual potential (Bruner, 1974; Rogoff, 1995; Vygotskij, 1978, 1986). Wittgenstein (2012) makes this clear and explains that understanding is not a 'mental process' at all. Hence, knowing and understanding are not, in this study, viewed as abstract, mental activities. As a result, what is studied are the interactions between humans (teachers and students) and their interactions with tools. Human action employs mediational means, such as artefacts and languages; these mediational means shape the action in essential ways (Wertsch, 1998). From this analytical stance, the point of departure is, when I investigate research questions one and two that humans need to master relevant tools/artefacts in an activity in order to make sense of the world and act in accountable manners (Säljö et al., 2006). Thus, the object of analysis in relation to those questions includes a concrete activity where human participants interact with each other and through the use of mediating tools (Wertsch, 1998). Altogether, by aligning with this theoretical perspective, interaction analysis (Jordan \& Henderson, 1995) is used for the empirical investigation of individuals' interactions with each other and with artefacts such as digital learning resources in the social science classrooms.

\section{Actor Network Theory}

An ANT approach emphasizes that action is shaped by relational materiality and performativity. It asserts the principle that an entity (either human or non-human) takes its form and acquires attributes as a result of its relations with other entities (Latour \& Woolgar, 1979; Latour, 1993; 2005; Law, 1987). So what can be studied is how social and material actions together constitute a particular enactment. This means that the interactions between humans and between humans and non-humans (i.e. technology) become significant. Within this approach it is not the humans' interaction with the tool, their use of the tool that can be studied. It is instead the property of involvement of both social and material practices that is central (Callon, 1986; Ashmore, 1993). This perspective consequently helps me to answer the third research 
question. With this approach I can investigate and analyse the emergence of the learning conditions in relation to social concerns (teachers and students), but also in relation to how material actors (technology as well as other objects and matters) form activities.

\section{Entities - action - networks}

ANT emphasizes the active participation of non-human forces. That is a materiality that runs through and across all entities, both human and non-human (Bennett, 2010). All these entities or actors are viewed as articulating bodies able to translate their will into the language of their own (Law \& Hassard, 1999). Therefore, the position I take with an ANT lens is that an actor is not defined by its inherent qualities, but by what it does with others. It/he/she does something, and that action makes a difference (Fenwick \& Edwards, 2010; Hekman, 2010). The actors' articulations, their interactions and the effects of those articulations and interactions are central. Together they build $a$ network, which is an assemblage or gathering of materials brought together and linked through interaction. Together the actors perform a particular enactment (Law \& Hassard, 1999). The network, the actors' interactions, may be messy and incoherent, and also spread across time and space (Fenwick \& Edwards, 2012a). A textbook or an educational article, for example, each bring together, frame, select and freeze in one form a whole series of meetings, voices, explorations, conflicts, and possibilities explored and discarded. Yet these inscriptions appear seamless and given, concealing the many negotiations of the network that produced them. A textbook or article can also circulate across vast spaces and times, gathering allies, shaping thoughts and actions and thus creating new networks. The more allies and connections there are, the stronger the network becomes (Law \& Hassard, 1999). I use the network metaphor to include and discuss all the different actors and their interactions in the classrooms where this study is conducted. Consequently, research questions that can be/are addressed are: What activities take place in a certain network? How do actors interact? What communication takes place between the actors and how is the network constructed by the actors' interactions?

From a perspective rooted in ANT, I assume that any change we might describe as learning, such as new ideas, innovations, changes in 
behaviour, and transformation, emerge through the effects of relational interactions made in networks (Law \& Hassard, 1999). In other words, what I study inspired by ANT is not where the activities of actors come from, but rather where they go - effects are crucial (Mol, 2010). Therefore, my ambition in using ANT is to keep the interactions between the actors in focus.

\section{Interaction - actors - translation}

The manifestations of the interactions in a network of actors are called translations. 'Translation' is the term used by Latour (1987) to describe what happens when entities, human and non-human, come together and connect, changing one another and forming links. When this happens, knowledge appears and develops. Therefore, drawing on ANT, my point of departure is that the connections (between the actors, in the interactions) that I can identify in my data not only work together but also work upon, or translate, each other, thus forming a network of coordinated things and actions. It is in this process of translation that knowledge emerges and changes hands.

Callon (1986) outlines a translation as having four different kinds of moments, which not necessarily happens sequential though. The first kind, problematization, is where an actor attempts to define the nature of the problem and the roles of other actors to fit the solution proposed (e.g. a student tries to understand what action to take with a school assignment). The second kind, interessement, is a series of processes that attempt to impose the identities and roles defined in the problematization onto other actors (e.g. the student tries to investigate what actors can support her/his efforts to complete the assignment; these actors might include texts, images, other students, a ruler, a computer, a mouse, a keyboard, etc). The third kind, enrolment, then leads to the establishment of alliances among the actors. For enrolment to be successful, however, it requires more than just one set of actors imposing their will on others; it also requires these others to yield (e.g. an image on a computer screen must eloquently espouse or provide benefits and the student may give up ingrained ideas or opinions). Finally the fourth kind, mobilization occurs as the proposed solution gains wider acceptance and an even larger network of absent entities is created through some actors acting as spokespersons for others (e.g. a 
detail in the image on a computer screen is highlighted by a cursor, a student aligns with her eyes to the detail, the mouse is moving at the interface to connect to another detail on which another student focuses and articulates, etc.). So, every connection through interaction between actors causes a transformation of what has been articulated. This is what, in this context, I call a translation.

But a translation does not always mean a complete translation. It is of interest within an ANT approach not only to analyse the interactions that appear, but also those that come to an end or those made impossible (Law \& Hassard, 1999; Mol, 2010). In this study I use the term problem space ${ }^{17}$ to embrace the situation that can occur in a translation before it has succeeded in becoming a complete translation, if it succeeds at all. A 'problem space' embraces the moments where a student and other actors attempt to define the nature of the problem and the roles of other actors to fit the solution proposed. A problem space also embraces the attempt to impose the identities and roles defined onto other actors and the moment where the actors try to establish alliances among the other actors. The two conceptual metaphors - translation and problem space - are analytical tools used to describe the associations between technology, students/teachers and classrooms; how knowledge can be translated in interactions between people and materiality. The concepts are applied in papers IV and V to accentuate how ideas, practices and technologies are combined and shape each other (i.e. to describe the ways the information on the computer screen in interaction with the students translate the performance into verbal utterances that suggest solutions to the educational tasks). These concepts are not used as categories or coding schemes in the analyses. Instead, they offer a vocabulary to characterize the interactions that appear, cease or become unfeasible. They are used not to discuss why something happens but what happens with that which happens.

According to this sketch of ANT, subsequently, material-discursive analysis (Callon, 1986) is used in relation to the final research ques-

\footnotetext{
${ }^{17}$ This term is also used by others, including Gill \& Hicks (2006), but they define it slightly differently due to a different theoretical approach.
} 
tion. The ANT metaphors help to call attention to the heterogeneous nature of an educational practice. By attending to both human and nonhuman interactions - the networks established in the social science classrooms - the role of the technology can be looked upon as always connected to a complex web of associations that shape every facet of educational interactions (Lee, 2009).

Because two theoretical approaches influence the work and the vocabulary, I will, from this point onwards, at times use concepts from both the theories in parallel in the text. Sometimes I will use both the terms human (together with artefact or tool) and the term actant (instead of actor). By using this written construction, human and artefact/actant or human and tool/actant, I want to show my awareness of what the respective theories denote. The term actant (Latour, 2005), commonly used within ANT instead of 'actor', will also be used further on to emphasize an analogous treatment of human and non-human actions and their actor-ship. I also use this term in papers IV and V. So, from this point forward I will do the same (use the term actant). Also, context and network are sometimes used in parallel to emphasize my consciousness of the implications from the theories and their different vocabularies.

\section{Central Concepts}

Besides the concepts introduced within the frame of the theoretical perspectives I will also introduce two more that are central in this study. These concepts are learning activities and learning conditions.

\section{Learning activities}

The term learning activity in this study is used to prevent preconceived associations with the term 'interaction'. The term 'interaction' is central in both theories used in the study. Depending on which theory is in focus, different concepts are associated with the term. This plays a role for the decision to use 'learning activity' (Lantz-Andersson, 2009). Learning activities in this study are understood as inter-dependent activities in the studied context (research questions one and two) or network (research question three). They are to be seen in the form of interactions among all involved participants and artefact/actants, for 
example, the students, the teachers, the data, the technology, the tasks, etc. in the educational environment.

In this study I first explore human interaction with artefacts in relation to an educational setting. Then I investigate interaction between actants in the educational setting. This is to study what is happening in these connections when: a) humans use artefacts and b) actants interact. In a socio-cultural perspective this would be described in terms of mediation, sense making and meaning making. Vygotskij (1978) makes a distinction between sense and meaning where sense refers to the manner in which people understand their world and concepts, and meaning refers to the more general lexical meaning of the word. Kress (2010) uses the term 'meaning making' as a basis for understanding all interactions. In Callon's (1986) view, it is in the interactions, within the translations, where meaning or knowledge changes hands between the actants. To avoid different associated notions, with the term interaction, the concept learning activity is used for my understanding of all interactions taking place between all involved humans and artefacts/actants as the studied practice is a learning environment. It is the activities, the interactions in that kind of practice, that are of analytical interest in this study. Thus, the focus is on the activities created in the interplay between the participants and artefacts/actants. Consequently, this concept is used in the concluded papers of the study and again, it refers to all kinds of interactions. This does not mean though, that the term 'interaction' is not used or is excluded in the study.

\section{Learning conditions}

In this study my opinion is that by studying the learning activities, it is possible to reach an understanding of emerging learning conditions. Depending on which theory is in focus, the term 'learning condition' can be understood differently. In a socio-cultural perspective, human action and learning processes are seen as intertwined in, and dependent on, the surrounding culture. They depend on how knowledge is shared and mediated via sets of tools available in the particular community where a human acts (Säljö, 2005; Säljö, 2010a; Wertsch, 1998). Consequently, the context and mediating tools affect and influence 
how people think and behave (Wertsch, 1998). This can accordingly be seen to establish the conditions for learning in an educational practice. From an ANT perspective, this is a process constructed by assemblies or gatherings of myriad actants that interacts, order and govern the educational practice. The classrooms, teachers, teaching, students, knowledge generation, curriculum, policy, standardized testing, inequities, computers, etc. together stipulate the learning conditions. They can, with this approach, be seen to emerge from all interactions and the negotiations between all participants and artefacts/actants.

To be able to study the third research question in a way that corresponds to the overall aim of the study, I have chosen to see learning conditions as constructed in the educational settings by all participants and artefacts/actants. This means that the activities are not seen to be performed under established conditions in a social context; instead, it is the possible actions of all actants that are seen to construct the learning conditions in the context or the network. The learning conditions are in this way seen as distributed in the networks of the actants and through the interactions from which they emerge. To describe this in more detail, it is possible to think of what appears to be the agency of a teacher, a student or a teaching material which is always an effect of the different actants' forces. This include their own actions, desires, capacities and connections that move through them, as well as the forces exerted by other actants as texts and technologies in every educational encounter. These networks move or dissolve through the actants' practices; their actions are determined by the interactions in such network - the classroom's everyday interactions (Fenwick \& Edwards, 2012b). Hence, I see the educational practice as circulating forces that get things done through a network of actors acting upon one another - the learning conditions emerge. Therefore, by deconstructing the learning activities in an educational setting, this enables me to arrive at understandings of the emerging network and thereby the distributed learning conditions.

With this outline of how the chosen theoretical perspectives shape the study, the next chapter moves forward and discusses methodological concerns, the research process and considerations of ethical issues as well as how data have been gathered and analysed. 


\section{Methodology and Research Design}

This chapter presents and discusses methodology and research design. First a description of the set-up of the study is given. Then the research process is described, including how the studies relate to each other. Thereafter the methods for data gathering are presented as well as accounts of the data gathering and the analyses done. Also, ethical considerations and procedures are described. Finally, reflections on methodological issues in the different phases of the study are provided.

\section{Set-up of the Study}

To reach the overall aim of the study, three different empirical materials contribute. The material was generated during a period reaching from Dec. 2009 to Feb. 2011. They were generated during three different phases of the study, each one contributing to a specific research question.

- Phase 1: Visual storytelling technology in relation to teaching in social science in primary school analysed with a focus on the teachers. The data were generated when 16 social science teachers were introduced to the technology and trained in methods for visual storytelling.

- Phase 2: Visual storytelling's usability for primary students in social science education analysed with a focus on the students. The data were generated by carrying through a usability study in a primary school setting. One social science teacher and a class of 28 grade 6 students (12 years old) participated.

- Phase 3: The emerging learning conditions in social science education when methods for visual storytelling are employed analysed with a focus on all actants. The data were generated in three different primary schools, four teachers and their four social science classes, comprising 
98 students, participated. The students were in grades 4 through 6 (10 to 13 years old).

To be able to conduct the different phases in the study, first awareness of and an interest in the application, the Statistics eXplorer platform, had to be created among social science teachers. Therefore, initially I wanted to learn about a) a teacher's use of the storytelling methods, b) the use of Vislets when teaching and c) students' learning activities when using the Vislets. This was to enable me to speak with teachers about these issues with the intention of associating them with the study. I also needed to know about the relevance of the information the data download/the official statistics - in relation to educational goals in the primary school social science curriculum (Swedish National Education Agency, 2011). For these reasons, I conducted a pilot study. So, in close collaboration with one teacher and one grade 6 social science class, we tried out the application in relation to teaching in social science. In a worst-case scenario the results from the pilot study could have shown that there were few possibilities for using the visual storytelling methods for educational purposes. Fortunately, the results pointed in the opposite direction.

From this point I proceeded with the process of associating teachers to the main study. I introduced the study to the head of the educational department in a municipality in Sweden. I got approval to proceed and contact all the headmasters for compulsory schools in one area of that municipality (see Appendix A). These headmasters gave permission to invite the social science teachers at their schools to receive in-job training to learn visual storytelling. Thereafter, an information meeting was held for these teachers about the visual storytelling methods and the plans for the forthcoming study (see Appendix B). Teachers who became interested aligned then to the study (16 teachers). The research process in the study and the attempts to generate data during the different phases of the study is described in the following section.

\section{Research Process}

As pointed out earlier, the process of carrying through the study supposed an abductive approach to achieving the aim of the study. This 
approach oscillates between theory, empirical data and analysis (Alvesson \& Sköldberg, 2008) and is apparent in the sequential structure of the study and the appended papers. In the first phase, to be able to answer the first research question it was crucial to introduce the visual storytelling methods in relation to an educational setting. This was to explore the possibilities for educators to (independently) incorporate them into their teaching practices and social science courses as well as to customize the visual storytelling application for educational purposes. With results from the first phase of the study, showing that teachers were able to use the visual storytelling methods to create Vislets, the second phase was initiated. I could move on to examine the usability of Vislets for students in primary school. Finding that the Vislets could be used by students, it was then possible to proceed to the final phase of the study and explore the third research question. But before exploring that question, I started phase 3 by reflecting on theoretical and methodological issues that had arisen in the first two phases in relation to interdisciplinary aspects. These were thoroughly investigated as this study can be seen as a part of the GVA field (see p. 33) and it was important to also contribute to that field (see paper III). So, the empirical material used in that investigation comes from the third phase and were analysed with at sociocultural perspective. The data in phase 3 were otherwise analysed with ANT approaches in relation to the research question in focus.

Moreover, another example of the study's abductive reasoning in this work is the development of methods for data production. The level of detail an ordinary video camera provides proved, in the analysis done in phase 2, to be a bit limited in relation to the learning activities in focus; the actions on the screens were especially difficult to document. Therefore the methods were also refined in the final phase of the study. The ability to capture the actions on the computer screens was added. In other words, theoretical and methodological gaps that became apparent during the research process were explored and compensated for in the subsequent phases and investigations. 


\section{Methods Applied}

A methodological consequence of the theoretical perspectives guiding this work has been the need to find methods that focus on and capture activities of social groups and their usage of tools as well as, in the later analyses, the activities of all actants (including the technology) in the school context/networks. So, in relation to the study's overall aim, the research questions and the desire to get a nuanced image of the studied object, multiple methods of data collection (see figure 8 ) were included in the study (Denzin \& Lincoln, 2005).

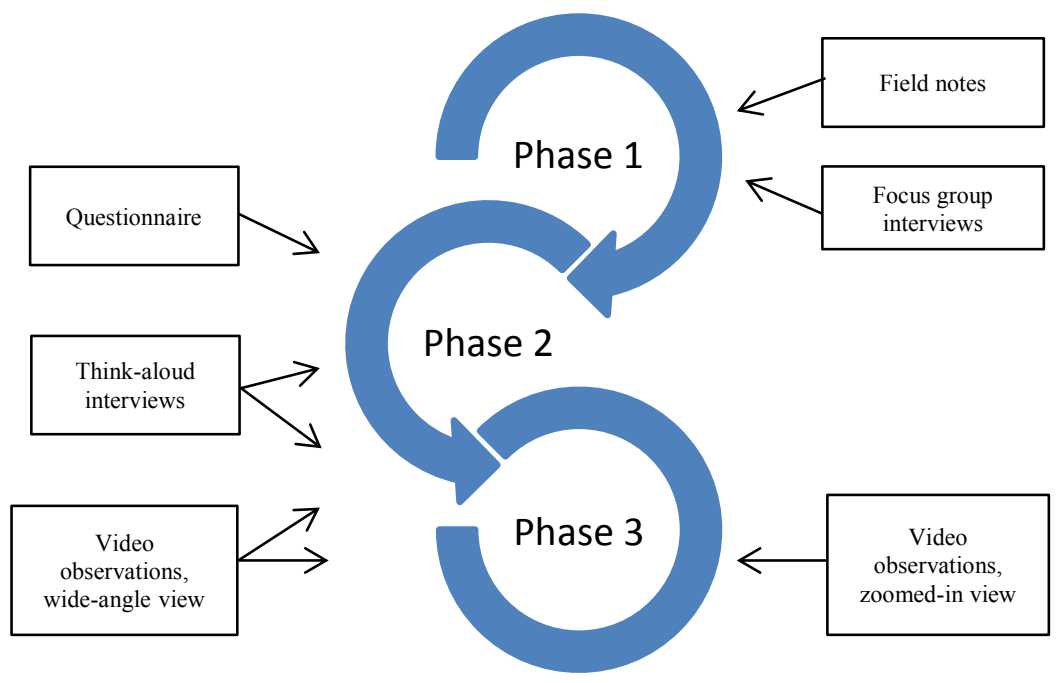

Figure 8, Overview of data gathering methods applied in the study. A collection of students' text products was also made in Phase 3 of the study, but those data have not been used for analysis in that phase of the study.

In all, the empirical material includes:

- field notes from six occasions (ca 90-120 min each),

- two focus group interviews (ca $20 \mathrm{~min}$ each),

- 26 questionnaires,

- 15 think-aloud interviews (ca $10 \mathrm{~min}$ each),

- 35 wide-angle recordings $(16 \mathrm{~h})$,

- 42 zoomed-in recordings $(22.5 \mathrm{~h})$. 


\section{Field notes}

In the first phase of the study I made field notes during the sessions with the teachers who were learning to use the visual storytelling technology. They can be seen as notes on the Who, What, When, Where and How of the activity. They comment on: what happened, who was involved, when it was, and how I interpreted the situation (Newbury, 2001). The notes can be seen as statements bearing upon events that were experienced by me principally through watching and listening and are as reliable as I, as the observer, can make them (Bailey, 2007).

\section{Focus group interviews}

In the first phase of the study, focus group interviews with the teachers were also conducted. By engaging the participants around a theme, in this case the handiness of the storytelling methods, this method capitalizes on the communication that occurs in order to generate data (Morgan, 1997). The basic idea of using this kind of interview in the study was that group processes can help the participants to elaborate on and clarify views and reasoning that would be harder to access in individual interviews (Patton, 2004, p. 336; Rabiee, 2004). The interview guide (see Appendix C) was structured around a set of carefully predetermined themes: the application's handiness, relevance for education, and thoughts on didactics. The guide ensured that the same themes and formulations were used when communicating with the interview groups. The focus group interviews are a complement to the observational notes (Patton, 2004).

\section{Questionnaire}

In phase 2 , one of three methods chosen to perform a usability study was to use a questionnaire (the others were think-aloud interviews and video observations). A questionnaire was thought to be suitable, as the methodological question was how to interpret a discourse in the classroom, which was descriptive in character. The actions were inexplicitly expressed and it was hard to understand what was going on just by listening to the talk and observing what the students were doing. The aim with the questionnaire was to estimate the performance of the students. The tasks in the questionnaire were made to look like typical tasks assigned to students in that age group, and the instructions were discussed with their teacher to clear up questions about the procedures. 
The questionnaire/the educational tasks were also made in relation to the Vislet that the students were working with (Stenliden \& Lundblad, 2012/09/18). Each question was coded (Chen \& Yu, 2000) in order to analyse the usability goals and what level the task concerned from a content point of view (see Appendix D).

\section{Think-aloud interviews}

In addition to the questionnaire, a combination of interview and thinkaloud reports was used in phase 2 . The idea of using think-aloud interviews was that they would allow me to ask the participants to use the application while they were continuously speaking out loud using any words that came to them while they were working on assignments or completing tasks that involved the application (Nielsen, 1993, p. 209). In this kind of interview the students could verbalize thoughts as they moved through the user interface. Think-aloud interviews are seen to provide a valid source of data about human thinking, especially during language-based activities in combination with interactions with technology (Charters, 2003). The tasks employed during the interviews were examples that the students were familiar with from the lessons. Also, an interview guide was developed that included follow-up questions (see Appendix E). The idea of using an interview guide during the think-aloud interviews was to make the interviews more organized and complete by delimiting the issues explored in advance and following up on any issues that may have been noticed during interactions when students were working on the tasks (Patton, 2004).

\section{Video observations - wide-angle view}

In both phases 2 and 3 of the study, video observations were made with a wide-angle lens. This was to capture as much as possible of the ongoing learning activities in the classroom during the sessions. The method allowed me to thoroughly document the visuals, actions, gestures, facial expressions, positions and movements (Heath et al., 2010). The video recordings allowed me also to view and analyse the material over and over again. Additionally, the video recordings provided opportunities to thoroughly discuss the data with other researchers, thus increasing the validity of the analytical process (Mondada, 2006). 


\section{Video observations - zoomed-in mode}

In phase 3 of the study, in relation to the third research question, the learning activities were also captured in a zoomed-in mode. This was done with the help of recordings made by Camtasia Studio (TechSmith Corporation, 2011).$^{18}$ The argument for using these recordings was that they could capture in detail what was happening on the computer screen while the students and the interface interacted. Patton (2004) suggests that additional visual documentation can be supportive for the researcher when recapturing the research interventions.

\section{Data Gathering and Analyses}

\section{Phase 1}

The goal in the first phase of the study was to answer the first research question. In order to do that, the visual storytelling methods were introduced to teachers to investigate how they could use the methods, and to customize them in relation to their teaching purposes and in relation to social science education more generally. The data used in this first phase was collected in close association with an implementation study at 10 different secondary schools. I have used only a small amount of the data produced in that study. The used data concern 16 social science teachers and were generated in the form of field notes and focus group interviews.

\section{Data gathering process}

To conduct this initial investigation, I first had to construct an in-job training course. A web page with course material was created in cooperation with NCVA for training the teachers (Lundblad \& Stenliden, 2012). Six different teacher-training sessions were organized; on average, each teacher participated in four of these. The teachers could, if they wanted to, use the web-based course instructions between the meetings. I collected the data in connection with the organized meetings when the teachers were introduced to the tool and learned how to us the platform's visual storytelling methods. The teachers organized the content and the task independently by involving

\footnotetext{
18 This software allows recordings with the computer's webcam, audio recordings with the computer's microphones, as well as recordings of the computer's screen.
} 
the storytelling methods for exploring demographic indicators according to the curricula. This means that educational material for the students, Vislets, were produced by the teachers based on indicators from databases such as the World DataBank, $\mathrm{SCB}^{19}$ and $\mathrm{WHO}^{20}$ and concerned the period from 1960-2009. The Vislets that the teachers produced were published on a common educational blog (Stenliden \& Lundblad, 2012/09/18).

Field notes were taken during the six teacher-training sessions (each session approximately 90-120 min). The observations were not made throughout entire sessions. Instead, they consist of different occasions that occurred during the sessions. Also, I took notes just after each session was finished. Two focus group interviews were held, where 13 of the teachers that participated were divided into two interview groups (three of the teachers were not able to take part). The group size of six or seven teachers was large enough to generate rich discussions but not so large that some participants were left out. I tried to moderate and nurture disclosure in an open and spontaneous format as my goal was to generate a maximum number of different ideas and opinions from as many of the teachers as possible. No resources, such as computers, lecture notes or pictures of the application, were available at the interviews. The interviews took approximately 25 minutes each. They were recorded by a smartphone and I transcribed them into text-based manuscripts.

\section{Analysis}

The analytical attention was directed towards the interactions between the teachers and the visual storytelling application. The actions observed, by analysing the field notes, were thus actions directly connected to the actual interface, but also actions that emerged in the situation as a whole - between the involved teachers, the experts and the social practice within which the in-job training took place. Also, individual examples often emerged as particularly interesting, as these

\footnotetext{
${ }^{19} \mathrm{SCB}$ is the central bureau of official statistics in Sweden, named Statistics Sweden in English.

${ }^{20}$ WHO is the directing and coordinating authority for health within the United Nations system. It is responsible for providing information on global health matters.
} 
allowed issues to be opened up and pursued in more depth. That gave an understanding of key issues that progressively unfolded. In the analyses of the focus group interviews, attention was paid to the relations between the following themes:

- the curriculum's educational goals linked to possible content to upload to the platform for the production of Vislets,

- the teachers' ability to achieve a growth in knowledge of the visual storytelling methods,

- the production and publishing of Vislets by the teachers.

The shape of the storytelling methods and their possible use by teachers are presented in paper I.

\section{Reflection}

During the work with this phase of the study, technological adjustments were made in relation to the teachers' use of the storytelling methods and the educational context. This is delineated by Lundblad \& Jern (Lundblad, 2013; Lundblad \& Jern, 2012). It was then possible to continue the research process.

\section{Phase 2}

To answer research question two, a usability study (Hornbæk, 2006) was conducted. This was to find out about the usability of the technology in relation to the educational setting, the age group of students, etc. To obtain this knowledge was central in the second stage of the study. The data in this phase were generated using a questionnaire, think-aloud interviews and video observations made with a wide-angle view.

\section{Data gathering process}

The usability study ${ }^{21}$ was carried out in a primary school setting with one social science teacher and her class of 28 students. The students were 12 years old. The classroom was equipped with five stationary

\footnotetext{
${ }^{21}$ Motives for this choice of study are given in the theory chapter under the section 'Theoretical Aspects and Interdisciplinarity', where the impact from another research field is explained and discussed.
} 
computers and a laptop connected to a smart-board. Also available was access to a form room equipped with five desktop computers. All learning activities in the social science classes were performed in a half-class situation and were followed for three weeks. During this period Vislets were used as educational materials by teachers and students to process information and to solve social science problems. The investigation used both qualitative and quantitative methods: 1) a questionnaire, 2) video observations and 3) think-aloud interviews. All 28 students participated and worked with the questionnaire; 26 of them completed the assignments. I made twelve video observations and 12 interviews.

The questionnaire (see Appendix D) used was introduced as an ordinary assignment for the students in the classroom. This was an attempt to avoid an inappropriately formatted questionnaire that could confuse the respondents, lead them to miss questions, or even cause them to throw the questionnaire away (McColl, 1994). The students were allowed to work with the questionnaire as they would usually work with other assignments, and they tried to answer the questions by involving the Vislets. There was no time limit to complete the questionnaire and most of the students used approximately two lessons. After the students had proceeded and completed their assignment, providing written answers to each question, this material was collected.

The observations were made through video recordings with a wideangle lens. The video camera was most often placed on a tripod at the back of the classroom. The recordings started at the beginning of the social science lessons and continued until the end (30-40 min). During these lessons the students were working in pairs or some in threes. Leaving the video camera in one place like this, instead of moving around with it, aimed at minimizing disturbances that always are caused by bringing a video camera into a classroom. Nevertheless, the presence of the equipment most likely had some effect on how the students acted and the way they expressed themselves. This effect cannot be avoided though, and can be referred to as the 'observer's paradox' (Labov, 1972). 
The think-aloud interviews were recorded with both an ordinary webcam (wide-angle view) and by the Camtasia Studio (zoomed-in view). This enabled me to also record close-ups of the students, and to capture the audio as well as what happened on the screen. The argument for using two types of recordings was to get an overview of the whole situation as well as to capture in detail what was happening on the computer screen (see Figure 9). I wanted to keep the sessions where think-aloud interviews were held as relaxed as possible, even if it meant that the degree of information varied among them. The students were working in pairs during these sessions, which gave them opportunities to support each other. I chose to sit next to, not across from the students to minimize intimidation (Nunan, 1992). I tried not to prompt in any way that would influence their thinking or expressions, but sometimes I asked questions that helped me understand what they were doing when interacting with the interface or why they chose the actions they did. At the end of the think-aloud session, I also asked the participating students some ordinary interview-type questions. The interviews were approximately 10 minutes long. I have tried to use the think-aloud techniques by designing the methodology with great care, that is, I have tried to avoid over-influencing the participants, to design tasks of appropriate type and level of difficulty, to consider the degree of prompting adequately, and to keep in mind the method of analysis.

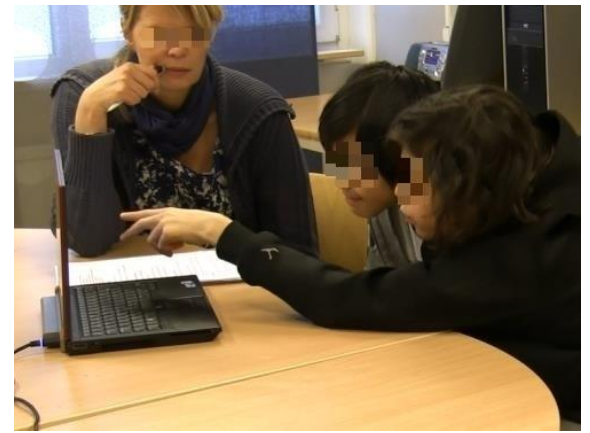

- Hur menar du?

Alltså, man ser ju här, prickarna!

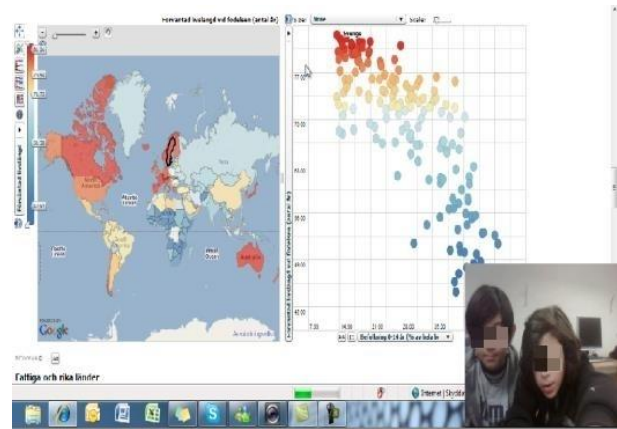

- What do you mean?

- So, you see here... the dots!

Figure 9, Excerpt from speak-aloud interview III, School 1, 2010, January 28, time 10.32.47. 
Analysis

The analyses of the data were done with a set of usability heuristics (ISO 9241-11). They apply to the interaction of people and information systems, where interaction is referred to as a dialogue, and in turn of effectiveness, efficiency, and satisfaction. In the analyses these heuristics are used as:

- effectiveness, in terms of performance, meaning the way that the students in the school setting were successful in understanding and manipulating the Vislet's interactive tools. This was assessed through the questionnaire by analysing task completion, accuracy and quality of outcome in relation to the coded questions.

- efficiency, in terms of accuracy and completeness. These were assessed through both the questionnaire and the video recordings captured with the wide-angle view. The analyses were linked to how successful the students were in a) understanding the connections between the dynamic linked views offered by the Vislet, b) treating statistical information by using the Vislet, c) understanding the concepts of living conditions, GPD per capita and $\mathrm{CO}_{2}$ emissions, and d) comparing their own living conditions with those of people living in other environments.

- user satisfaction, in terms of the users' apprehension or told experience. The interviews were analysed for this matter. This was done in relation to the participants' expressions and attitudes towards the tool, their comfort with and acceptance of the system and their experience of learning.

The results from this usability study are presented in paper II.

Reflection

To critically discuss this kind of study I agree with Gould and Lewis (1985) and argue, first, that the meaning of the term 'usability' is largely determined by how we estimate, assess or measure it. Second, it is difficult or impossible to 'determine' usability in any straight- 
forward manner. The thought is that through operationalization of the usability construct, there are aspects of usability that can be 'measured'. Third, many user-centred approaches to design depend critically on measures of the quality of interactive systems (Whiteside et al., 1988). The overall problem with the argumentation is that, from the beginning, it is necessary to decide on or know a preferred outcome of the interactions between the technology and the human. Hence, the investigation of a technology's usability becomes a sort of evaluation.

This usability study tries to some extent to do this, but it differs from ordinary usability study set-ups since it is conducted in a classroom setting and not in a lab situation/constructed situation that otherwise is more or less standard (Field \& Hole, 2003). Instead, the interactions between the students and the technology are allowed to be influenced by the contexts in the classrooms. I viewed this to be more genuine in relation to assessing the usability of the technology as that is the workplace where the technology is actually used. The assignments in this study are therefore not completed in controlled circumstances but under circumstances that are common in a classroom. This usability study also adds diverse methods of data generation, for example, the use of video observation to provide qualitative information. My standpoint is that, together, these kinds of data give a broad sense of the usability as different aspects can be highlighted. With the help of video recordings, for example, the efficiency could be analysed in a way that made it possible to grasp aspects that had not been thought of in advance. The effectiveness in this investigation is presented in a quantitative manner and, in parts, the efficiency as well. This kind of result presentation can be seen as intractable due to the number of participants, but I claim that the number of participants (28 students) can constitute a foundation for this kind of result presentation. ${ }^{22}$ In most usability studies there are no more than five or six participants, and this number of participants usually shows approximately $80-90 \%$ of the problem spaces concerning a tool's usability (Virzi, 1992). Altogether, despite the objections discussed, I view the investigation outlined in

\footnotetext{
${ }^{22}$ Usually there should be at least 100 participants in a quantitative study using this kind of result presentation (Bryman, 2011) and the number of students represented in this part of the study would therefore be too low for this approach.
} 
paper II as effective in answering the second research question, and so I could proceed with phase 3 .

\section{Phase 3}

In this phase I worked with two different tasks. First, due to theoretical and methodological issues that arose in phases 1 and 2, I decided to deliberate on these further. ${ }^{23}$ Second, I also explored research question three. Both of these investigations build on the same empirical data. The data were generated in three different primary schools in a municipality in Sweden. The data collected include video observations with a wide-angle view and video observations with a zoomed-in view. ${ }^{24}$

In the following, first the processes for data gathering are presented and then the two different ways of analysing the data are described.

\section{Data gathering process}

Altogether, four teachers and their four classes, comprising 98 students, aged 10 to 13 years (grades 4 through 6), participated. No effort was made to reach different kinds of schools from a research viewpoint, and no comparisons between schools have been made. The data from these schools in this study have been treated equally and are to be seen as a single data set.

In this phase the participating teachers were first introduced to the GVA tool. They made lesson plans according to the Swedish social science curriculum, and organized the content and the tasks by involving the visual storytelling functions of the Statistics eXplorer platform (see Appendix F). They disseminated Vislets that concerned three different geographical levels: national, continental and global. The Vislets were published on a common blog used by all of the schools. Most learning sequences using a Vislet started with an intro-

\footnotetext{
${ }^{23}$ For further discussion on this issue see the chapter on theoretical perspectives under the section 'Theoretical Aspects and Interdisciplinarity' as well as the earlier section 'Research Process' in this methodology chapter.

${ }^{24}$ The students' text products in relation to their assignments were also collected in this phase, but they have not been used in the analyses.
} 
duction from the teacher. The teacher then gave the students information about the content and how to proceed in their work. The students then worked in pairs, using the Vislet.

In the first classroom I studied, the students were working with educational content about Sweden: its population, its incidence in different regions and indicators of people's living conditions. The students worked with this material for four weeks, and the learning activities were followed in all of their social science classes (nine different occasions, ranging from 60 to $120 \mathrm{~min}$.). They worked with two different Vislets. The assignments involved analyses of differences and similarities between their own (the students') and other people's living conditions in Sweden.

At the second school, the students also worked with two different Vislets in their classroom. The educational content was about Europe, focusing on different aspects of population (density, age distribution, etc.), level of education, work and economy. Over four weeks, I followed the students' work in all of their social science classes (12 occasions, ranging from 60 to $120 \mathrm{~min}$.). The assignments were about their own living conditions compared to those of people in the rest of Europe, with students compiling information to respond to questions about circumstances of life.

At the third school (two different classrooms) the students worked with educational content related to the whole world, focusing on different aspects including a) energy use; b) water - access to and use of fresh water; c) 'poor and rich countries' - population growth, life expectancy, and infant mortality; d) population - Where do we live?; e) the environment $-\mathrm{CO}_{2}$ emissions and economic impact. The students worked on these subjects for three weeks and I followed all their social science classes (16 occasions, ranging from 60 from $120 \mathrm{~min}$ ). They worked with five different Vislets concerning the content. The assignments were about the different living conditions in the world. The students were required to make compilations and had to consider questions about circumstances of people's lives in different parts of the world, including reasons explaining the development of the conditions. 
The video recordings made with a wide-angle lens were captured with an ordinary video camera, which was most often placed on a tripod at the back of the classroom. The aim with the recordings was to gain comprehensive and overall understanding of the particular learning sequences in the classrooms. I thought it was important to be able to study different aspects of the classroom and the regular classroom routines, as these would help me to create a more complete picture. The zoomed-in video observations with Camtasia Studio (TechSmith Corporation, 2011) allowed me to capture what was happening in more detail. It was especially important to be able to capture what was happening on the computer screens. The laptops' built-in webcams helped to minimize the impact on the students, and the recordings of what was on their screens were invisible to them. For ethical reasons, though, the students were informed that these recordings would take place (see Swedish Research Council [Vetenskapsrådet], 2002). Even following these procedures, it is assumed that the recording equipment had an effect on how the students acted. However, the captures allowed me to go back and forth between the different kinds of recordings (see Figure 10). At times I could just listen to the speech and look at the screen captures or shift to just look at and listen to the students. But most of all I used all three sources together in order to make observations in relation to the aim of the investigation.

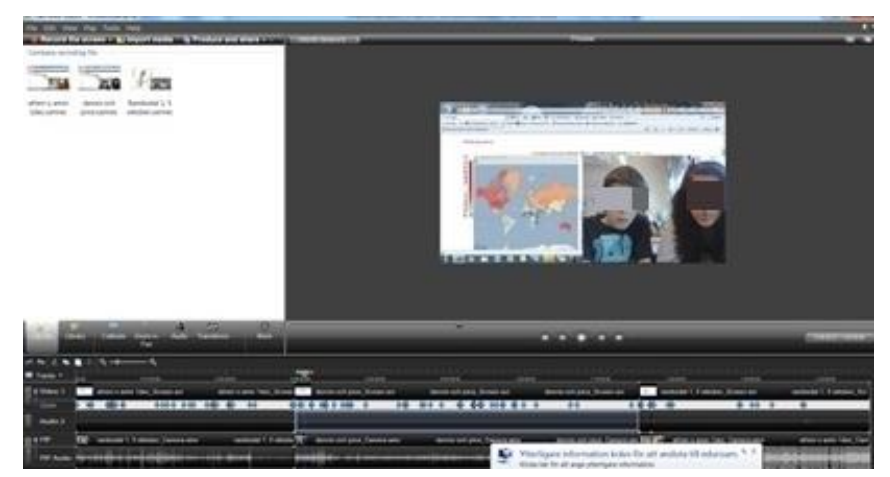

Figure 10, This is a screenshot of the Camtasia Studio's clipboard that illustrates how the screen displaying the Vislet together with the students and their talk are shown at the same time. 


\section{Analysis}

For the assignment to deliberate upon theoretical and methodological issues that ensued in phases 1 and 2 of the study, the collected data in this phase were analysed from a socio-cultural viewpoint (interaction analysis). For the second assignment in relation to the third research question, the same data were analysed with an ANT approach (material discursive interaction analysis). The analyses of the data with these different theoretical perspectives are described separately below.

So, interaction analyses were seen as appropriate for the first assignment as they focus on human activities such as verbal and nonverbal interactions as well as the use of artefacts and technology (Jordan, 1992). One underlying assumption in interaction analyses is that knowledge and interactions are fundamentally social in origin, organization and use (Jordan \& Henderson, 1995), which corresponds well with the socio-cultural perspective (Lave \& Wenger, 1991, 1998).

As the video material was substantial, first an all-embracing overview of the material was taken when cataloguing the material. My intention was then to identify regularities in the ways in which the participants used the resources of the complex social and material world. I looked for events of interaction that adhered in some manner and that seemed to be meaningful to the participants. According to Goffman (1981, 1983), social interaction is framed by a clear opening and a clear closing of the exchange between the participants. As I observed, I was looking for those beginnings and endings; hence an event can be seen as reflecting such a structure. Such structures are often perceived as externally imposed, but in fact they are collaboratively achieved by the participants (Jordan \& Henderson, 1995). I was interested in the ways in which the participants made that structure visible to themselves and each other. Kendon (1985) points out that spatial orientation also serves as a means of negotiating transitions from one segment to the next. Small manoeuvres in the direction of a new position are often observable as pre-closings (Jordan \& Henderson, 1995).

The next step in the analyses was to detect and select 'events' where I looked into the turn-taking system in more detail. I took into account a whole range of behaviours through which people can 'take turns', that 
is, participate in an interactional exchange system. Therefore not only 'taking turns to talk', but also 'taking turns with bodies' and 'taking turns with artefacts' were considered (Jordan \& Henderson, 1995). I studied how the students made their engagement (or lack thereof) visible to each other, what strategies they employed to gain entry, how the artefacts/the Vislets supported or constrained the particular participation structures and the like. This meant that I first detected such events and thereafter select and put them into collections. The selected events (15 pieces) were also transcribed. The goal was to transcribe the interactions, what the participants did and how they interacted in these doings, rather than to transcribe spoken words. To support this transcribing work, a chart was used that included images of the students, the teacher and the screen, which were added to the transcripts.

\begin{tabular}{|l|l|l|l|l|l|l|l|}
\hline $\begin{array}{l}\text { Time/ } \\
\text { image }\end{array}$ & $\begin{array}{l}\text { Students' } \\
\text { speech }\end{array}$ & $\begin{array}{l}\text { Students' } \\
\text { movements/ } \\
\text { gestures }\end{array}$ & $\begin{array}{l}\text { Students' } \\
\text { writing }\end{array}$ & $\begin{array}{l}\text { Screen, } \\
\text { map, } \\
\text { chart, } \\
\text { text }\end{array}$ & $\begin{array}{l}\text { Teacher's } \\
\text { speech }\end{array}$ & $\begin{array}{l}\text { Teacher's } \\
\text { movements/ } \\
\text { gesture }\end{array}$ & $\begin{array}{l}\text { Surrounding } \\
\text { sound/speech/ } \\
\text { movements }\end{array}$ \\
\hline
\end{tabular}

Table 1, The chart used for transcriptions.

The transcriptions of the modes were as equitably reproduced as possible, but it is always difficult or impossible for a researcher to be objective when doing this kind of work. Also, transcription is considered an interpretative and representative process according to Green et al. (1997). Therefore, the transcriptions that I made can be seen as texts that originate from a selection that represents the event and that have been interpreted - they are not the events themselves.

The second task in phase 3 was, as explained, to answer the final research question. The data were, due to the aim of the study and the formulation of the question, analysed with material-discursive interaction analyses corresponding to ANT. This helped to focus both the social aspects and the materiality of learning (Sørensen, 2009). To guide this analytical work, three principles highlighted by Callon (1986) were used. The first principle, a matter of style, showed me that I, as researcher, cannot censor the actants (teachers, students, the application, official statistics, etc.) selectively when they express themselves, their allies, their adversaries, or their backgrounds. I therefore tried to follow the actants without judging when they spoke about 
themselves or the environment. Callon (1986) argues that no standpoints should be privileged and nothing censured. The second principle, generalized symmetry, showed me that it is vital to use one and the same vocabulary to describe social and material objects. Callon says that it is not possible with an ANT view to have those playing different roles in the analysis. Thus, I made efforts to thoroughly describe and explain what I focused on, selected and had been doing in each analysis performed. I have tried to use a vocabulary suitable to the task, however, there are unlimited vocabularies possible. The third principle, free association, states that, as an observer, one has to abandon all $a$ priori distinctions between natural and social events (see also Lee, 2012). I therefore have to reject the view that there is a line that separates the two. The separation is rather the result of the analysis than the grounds for it. I have thus also taken into consideration the vocabulary of categories. Instead of pushing predefined analytical classes onto the montage of data, I have followed the actants and tried to identify how these define and associate with other actants, with which they build and explain their world (Callon, 1986).

Accordingly, when I started to analyse the video captures, my intention was to watch the captures in an open-ended and ongoing practice of making sense (Maclure, 2013). I tried to employ the moving imagery to open thinking spaces for a curiosity in which I tried to remain unsure as to what bodies might yet become (Lorimer, 2013). Therefore it could be said that the pieces I decided to select for analyses invited me in some way to 'handle' their contents. These pieces were not selected according to any theme or category; instead, the selection was about a reaction. Instead of being quite sure of what to choose, I could, with the selected pieces, experience what Stafford (2001) calls intensification; she argues that this type of compartmentalization, concealment and framing of the contents creates or offers a multisensory exhilaration of the senses. Via this intensification I was caught up in curiosity about certain pieces, and the more I looked, the more affected I often became by the video footage. MacLure (2013, p. 181) writes: 'If I feel wonder, I have chosen something that has already chosen me', I think this way of viewing the process of selection allows curiosity and some temporary point of indecision on the threshold of knowing, from where something unexpected might be produced. When 
analysing the selected video footage, the theoretical perspective helped me ask: What different kinds of connections and associations are created among the actants? What different kinds and qualities of the networks are produced through these connections? What different ends are served through the networks? I have tried to analyse how things are attracted to or excluded from the networks and how some linkages work and others do not. Fenwick and Edwards (2010) learned that ANT analyses focus on the minute negotiations that go on at the points of connection.

I am aware that what I have selected and have been able to see and speak of is interwoven with my context out of the spaces that are already known and familiar to me. I tried my best to prompt more fertile understandings and in so doing to ward off iterative responses to what I have been able to see and then speak of. The focus has been on how things are enacted rather than on attempting to explain why they are the way they are. I have translated the selected video footage of all the actants' (both human and non-human) articulations. I have transcribed human speech but have also used images of the actants and transcriptions of the application's interface and other material actants' articulations. In relation to this, I have also tried to consider who I am to speak and in whose name I am speaking. In my analysis I have striven to consider the kinds of translations and narratives I have tried to produce.

\section{Reflection}

To use and analyse the same data two or more times with different theoretical lenses could be seen as problematic. However, I think that analysing the same data in two different ways, due to the theoretical perspectives, has given me interesting insights. I think this opens up for different understandings of the material that are valuable. Things, that could not be recognized or spoken of when taking one theoretical perspective could be conceivable in the other.

In relation to the third research question, I believe I have been able to inspect a broad definition of what it means to interact, communicate and strategize in spaces that exist between social and material actants and/or outside spoken languages (McWilliam et al., 2008). By looking 
beyond dichotomies between the social and the material, the analyses helped me to answer the research question, and the results are presented in papers IV and V.

\section{Ethical Considerations}

During the different phases of the study, the code of the Swedish Research Council (2002) has guided my work. Ethical issues related to the study have been examined by the Ethical Review Board. As explained, before the study was carried out in the schools, information meetings were held with the educational supervisor in the municipality, the headmasters and the teachers. These meetings were held to seek permission to conduct the study, to ask who would be interested in participating, and to determine dates when it would be convenient to carry out the studies. Thereafter, at meetings held at each school before the study was conducted, the students were given information about the research verbally. The students and their parents were also informed in writing about the aim of the study and were told that participation was voluntary and that involvement could be terminated at any time. Students' assent was given in writing, as was their parents' informed consent (see Appendix G).

\section{Methodological Reflections}

Methodological reflections that were presented earlier in this chapter are made in relation to each phase of the study. In this final section of the chapter, reflections that are more all-embracing are put forward in relation to the research practice and the quality of the study as a whole (Golafshani, 2003). Larsson (2005) suggests that, without conceptions about quality of the research process, it is difficult to gauge the work. Using the quality criteria he suggests - qualities of the presentation, qualities of the results, and qualities in relation to validity - I believe that this study corresponds well to these requests. I argue that: a) by being conscious of different perspectives; by showing reflexivity; by displaying internal logic in the outline of the study and by handling ethical issues with care, this study matches the first set of criteria well; b) the study is entrenched in the empirical data as well as the analyses thereof which is shown by thick descriptions, by displaying nuances and richness, and also by giving clear overview without sacrificing 
complexity of the results and accordingly this corresponds well with the second set of criteria; c) by trying to adequately study and understand the phenomena that are in focus in this study and also by bringing suitable methods in doing so, this study also match up the third set of quality criteria about validity. In the following I have chosen to emphasize some aspects in this study to further illustrate the quality of my research practice.

As has been shown in this chapter, research can be understood in terms of constructions, where scientists create knowledge rather than uncover it, and there is no right or exact method that can guarantee an unbiased result (Hekman, 2010). Several discussions have, at least since the 1970s, tried to move and problematize assumptions about the practice of research having a neutral value. My view is that it is hardly possible as a social science researcher to argue that you are situated outside what is studied and can thereby present an objective image of reality (Denzin \& Lincoln, 2003, 2005; Hultman, 2011; Jones et al., 2010). It is important to be aware of that I, as a researcher, am in a process together with others. Scientific practice is therefore not only about putting the different participants, artefacts and actants together; it is also a process in which all the different entities affect or constitute each other (Pickering, 1995). So, as a researcher I am affected by the world, but I also have great opportunities to affect the world. In line with Höjgaard and Søndergaard (2011, p. 351), I want to underline that the 'choice' of phenomenon and the 'choice' of entities to be selected and highlighted in a study, in the analyses, depends on the researcher, on the research ambitions, and ultimately on how the phenomenon in focus is demarcated, defined and described. I try in this study to see all humans and artefacts/actants as important. However, there is a special focus among the social actants. The aspect of teachers and their use of the storytelling methods is not highlighted as such in the study. Instead, I have put a more specific focus on the relations between the students and the application, the data or teaching content. The choice originates from the fact that the main goal of education is building students' knowledge and therefore I have put their learning conditions in focus. This does not mean that teachers are unimportant in the learning activities nor for the learning conditions. The teachers have not been excluded in the analyses and they are considered in the 
learning activities if and when they take part in the focused interactions in the classrooms. But the study is delimited in that it does not ask questions in relation to teachers' practice in the classrooms. There are without question many interesting research areas concerning these participants/actants (the teachers), and hopefully they will be answered in the future, but this study does not claim to contribute in this respect.

However, it is also important to spell out that, by their very nature, the methods for producing and analysing data share a possible blindness, in that some things are clearly visible and other things easier to ignore or never to be seen (Barad, 2007). Additionally, I am well aware of the problem with the network conception: on what and where one should focus in conducting educational research. Miettinen (1999) makes this point in his critique of ANT, arguing that the network ontology is infinite and therefore unworkable for researchers. Indeed 'cutting the network' (Strathern, 1996) has always been deemed a necessary aspect of using ANT in research. But by being explicit about how I have been 'cutting', I argue that this enacts the effects of the research in certain ways. I think that any act of observation makes a 'cut' between what is included in and excluded from what is being studied or considered. This problem does not apply only to research that takes an ANT approach (Latour, 2005).

With the outline of this study as well as this discussion, I have demonstrated my awareness of different aspects of quality in this work. But to sum up, I will also mention what Latour and Woolgar (1979) remind us: the value and status of any text (construction, fact, claim, story, and this account) depends on more than inherent qualities such as these. The degree of accuracy of an account also depends on what is subsequently made of the story, not only on the story itself. I claim though that the knowledge that this study brings may contribute to several concerns within the educational society. Next, I will summarize my findings by focusing on the demarcated and defined phenomena that I have studied. 
Visual Storytelling Interacting in School

Part A: Methodology and Research Design 


\section{Summary of Papers}

The previous chapters have introduced the reader to the research setting, the theories and central concepts as well as the research design and processes followed in this study. This chapter will present an overview of the papers and the main results, which, together, contribute to achieving the overall aim of the study. As has been mentioned, the papers build on different theoretical perspectives, stress somewhat different aspects of theoretical concepts and highlight different aspects of learning activities, technology and education. This is due to the interdisciplinary character of the study, the different research questions and every other choice I have made. First are the results presented in relation to the first research question by a summary of paper I. Then a summary of paper II responds to the second research question. In these sections, socio-cultural views influence the studied phenomena. Thereafter, the interdisciplinary impact on the study's character and the study's theoretical approaches connected to a sociocultural perspective are deliberated upon in paper III. Finally, the results of papers IV and $\mathrm{V}$ are summarized. These papers respond to research question three, and the insights are guided by an ANT approach. As a final point the results are concluded altogether.

\section{Visual Storytelling Technology in Relation to Teachers}

\section{Paper I, Visual Storytelling Applied to Educational World Statistics}

In relation to the first research question the aim of the first paper is to introduce, explore and apply the storytelling methods in an educational setting. The paper explains why it is considered important to explore the possibilities for educators to incorporate visual storytelling technology into a variety of course subjects and teaching practices. The paper also introduces the shape of the technology and "visual storytelling' is exemplified by telling a geovisual analytics story about a country's development over time and shaping the measure of economic growth and well-being. Then the Statistics eXplorer platform is explained in more detail than in the chapter 'The Application for 
Visual Storytelling' and the visual storytelling methods are thoroughly presented. The empirical investigation is about possibilities and obstacles encountered by educators in relation to incorporating these tools into their teaching practices. The empirical material was generated and analysed during phase 1 of the study (see p. 51-53). The analyses are focused on 1) the relations between the curriculum's educational goals and the possible content to be downloaded to the platform for the production of Vislets, 2) the teachers' ability to achieve a growth in knowledge to connect to the visual storytelling methods, and 3) the circumstances in which Vislets were actually produced and published by the teachers as educational material, and the extent to which these were usable by the students.

The results show that it is possible to introduce and customize a geovisual analytics tool for educational purposes. The shape of the visual storytelling technology can be understood as having relevance for social science teachers. The technology and its production, presentation and dissemination features can, after some adjustments, be said to be usable for these teachers. The management of downloading data were e.g. developed as this was hold to be crucial for teachers to handle more easily. This means that it is now possible to load external

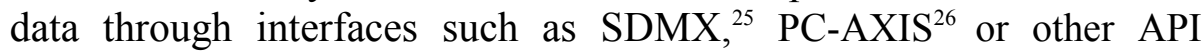
solutions ${ }^{27}$ and this is also referred to as an automated process in all the papers. One major result is also that it is possible for teachers to create and use visual stories in their teaching. After they are given a detailed presentation of the visual storytelling technology, teachers can begin to use it to produce educational material. The content of possible data download corresponds to content and educational goals in the curricula. The visual functions and the different hyperlink utilities offer relevant possibilities for producing visual educational material for social science education in primary school. Using the visual storytelling methods, the teachers were able to explore uploaded statistical

\footnotetext{
${ }^{25}$ A standard for Statistical Data and Metadata eXchange (SDMX).

${ }^{26}$ PC-Axis is a family of software consisting of a number of programs for the Windows and Internet environment used to present statistical information.

27 An application programming interface (API) specifies how some software components should interact with each other.
} 
content and produce visualized stories. They could then publish the stories online on their own educational blogs using the technology's publishing tool. From there, the students could start to interact with these Vislets. The contribution can be summarized as follows: the shape of the visual storytelling technology can be understood as an environment that allows teachers to produce, present and disseminate visualized stories to their students and use the visualized educational material in their teaching of social science. With the awareness of these results, it was possible to carry on and investigate the second research question.

\section{Visual Storytelling Technology in Relation to Students}

\section{Paper II, Educating Official Statistics Using Geovisual Analytics Storytelling Methods}

The second paper aims to investigate 12-year-old primary students' use of the geovisual analytics storytelling methods in an educational setting in order to correspond to the second research question. It examines the usability of Vislets, created by the visual storytelling methods offered by the Statistics eXplorer platform.

The introduction highlights that the use of GVA tools has in many ways changed the ways in which we can experience and explore our world (Kinzel \& Wright, 2008). The paper argues that it is important to gain a better understanding of how teachers and their students can elicit an understanding by exploiting these tools. The paper therefore examines the usability of a GVA tool for students' information processing and learning in social science education. Methodologically, the paper uses the usability framework offered by the principles of ISO 9241-11 (Bevan, 1995), that is, in terms of trying to assess the effectiveness, efficiency and user satisfaction. The empirical material was generated and analysed during phase 2 of the study (see p. 53-56).

The usability evaluation in this paper is central to the whole study since it shows that the visual storytelling methods can provide an opportunity to create meaning and organization from statistics and allow even young students to 'go beyond the information given'. The tool 
seems to efficiently support the students in their search for and the apprehension of connections between different kinds of statistical data. The user satisfaction among the students is extensive, at least when used as brand new tool. It is important to note that the long-term effects are unknown. The students express the view that a Vislet is resourceful, rich in information, apparent, immediate and clear. They also say that they appreciate the learning process while using the Vislets. Working with a Vislet creates positive emotions - it feels fast, easy, not tiresome, requires little input or effort, and it is fun, and the students think this is a good way to learn. In short, the Vislets, as a specific type of visual educational material, can be understood as usable by primary school students. The usability can be seen as relevant for their information processes. The Vislets seem to have potential to support students' learning processes and to be applicable in their social science education. With this established, it was possible to move on and investigate the third research question. But first, theoretical and methodological implications that had arisen in the exploration of the two first research questions were straightened out.

\section{A Socio-cultural Perspective - Implications for an Inquiry of Education employing Visual Storytelling}

\section{Paper III, How Can We Study Learning with Geovisual Analytics Applied to Statistics?}

This paper advocates theoretical and empirical assumptions related to a socio-cultural perspective for studying learning with tools such as GVA. The paper questions what we really know about the impact from multimedia environments on information processing and learning. It points at that multiple representational learning environments creates different framings for learning and in the worst cases, they are not just neutral but can even impede learning (Moreno \& Mayer 2000; Ainsworth, 2008). Consequently, the question ought to change from the simplistic 'Is multiple representational technology an effective learning environment?' to 'Under what circumstances, with which design factors, for which learners, performing which tasks, and expecting what outcomes is learning with multiple-representational environments sufficient?' The aim of the paper is to argue that, having 
acknowledged the complexity of the first question, we need to adjust and develop research methodologies to the complexity that the second question implies. The argument in the paper is that, to really understand learning with, in this case visual storytelling technology, we need to adjust conventional methods within GVA as well as within other fields of media technology and to employ methodologies that may be more appropriate in supporting this. The paper clarifies common learning theories applied in relation to the mentioned fields and when studying learning with a multimedia environment. It discusses the socio-cultural theoretical perspective on learning, advocating that it be applied in studying the complexity of learning in these kinds of environments. Further on, the paper elucidates the implications a socio-cultural perspective could have on the research design and methods. To contrast this, the paper gives an example of how the socio-cultural perspective on learning is used in a practice approach, to examine the geovisual analytics tool - the Statistics eXplorer platform - and students' interpretation of visual information, their learning and knowledge construction. This study was carried out in phase three of the study (see page 58-62).

The paper argues that a socio-cultural perspective makes it possible to gain deep insight into the learning processes taking place as it impacts the design and method. The study can thereby show how the learners used the technology, as the applied theory takes into consideration the fact that people differ in what and how they learn. The results presented in the paper as well as below are examples that illustrate the kind of results that can come out of analyses made with a sociocultural view:

- Students' use of and interaction with the Vislets: the analyses of the video observations showed that it was easy for students to understand and adjust the interactive functions and indicators, and to use the tool to understand connections between the statistical data.

- Students' meaning making and knowledge construction: the analyses of the video observations showed that the Vislets constituted an adequate learning environment for 
the students. The filmed learning sequences made it possible to examine how the students' tried to interpret of the representations. They talked with each other and at the same time interacted with the Vislet to prove that their statements about the content were correct. In this way they mediated the information and tried to make meaning.

- Students' experiences when using the geovisual analytics tool in their learning: the analyses of the think-aloud interviews showed that the students had a strong conviction that using Vislets leads to good learning and, furthermore, that the learning process differed from the one they were used to. They stated that this was a faster and easier way to find and handle information compared with the work they did during their usual lessons.

This kind of study, compared to what is common within GVA, may give a more complex view of the use of the technology in practice. This 'shifts the research focus to a different understanding of action and the character of everyday activity when using technology' (Talja, 2010 , p. 215). With the clarifications in this paper on theoretical and methodological issues, I was able to get past some obstacles that the study's interdisciplinary character raised in relation to a socio-cultural perspective. I could then proceed to investigate the third research question as I also knew the relevance of the technology's shape for teachers, the possibilities for teachers' use and the usability of the Vislets in relation to primary students.

\section{Learning Activities and Learning Conditions}

As explained earlier, because I view learning conditions as circumstances that emerge through the innumerable interactions that are negotiated among all actants in an educational setting, these learning activities were to be investigated. In two different papers I deconstruct the learning activities in different social science classrooms in primary schools, which enables me to understand the distributed learning conditions. Paper IV focuses on an understanding of the learning activities that were developed in the studied classrooms in general terms. Paper 
$\mathrm{V}$ builds on the results in paper IV. It tries to offer a more specific understanding of the learning activities and also to specify problem spaces that are found within the learning activities. So, building on the results from the first three papers, the final two papers contribute understandings of how social dimensions, technical and other matters create emerging learning conditions which correspond to the third research question.

\section{Paper IV, Understanding Education Involving Geovisual Analytics}

The aim of this paper is to examine learning activities ${ }^{28}$ involving visual storytelling technology in order to understand social science education in primary school. The paper builds on empirical data from phase 3 of this study (see page 58-64).

The results show that education involving geovisual analytics tools produces learning activities that provide students with:

- Opportunities to handle vast amounts of data. The students were able to handle the data-rich setting as they encountered and translated with the multimodal signs. The students' information skills, vision, and competence were developed in close collaboration with non-human actants: the task, the data/information, and the tool. The geovisual analytics tool directed the students to look at the screen in certain ways and to see relevant events within it.

- Support to participate in the learning activities. The nonhuman actants, the visual information, and the semiotics helped and strengthened the students' ability to take part in the learning activities. Together, the data-rich setting and the students create intelligibility, where knowledge emerged from the learning activities. Hence, the support of this ability, to take part in the learning activities, is central. The learning activities - the networks - supply the

${ }^{28}$ The concept of learning activities is elaborated on and explained on page 42-43. 
students with a 'knowledge of seeing' that situates the events visible on the screen within the work life of the particular community of students.

- Benefits to achieve various educational purposes. Students took part in the learning activities both for the purposes of enrolling as humans and learning some content, which is in line with Osberg and Biesta (2008). The geovisual analytics tool prompts the students to simultaneously take part in the processes of attending to the content and to human enrolment by offering highlights to search for, follow, and focus on during the activity. The technology empowers the students to achieve their diverse purposes.

The conclusions are that intelligibility is created in the emerging learning activities, where the data-rich setting and the students together generate knowledge. This emerges from the heterogeneously constructed networks. These show that learning is complex in character, continuously ongoing in an intertwined, multimodal, multiple, and content-focused mode. The paper argues that due to the close collaboration between the actants in the networks, and the high level of complexity, it is vital to investigate these learning activities further to find out more about the alliance of data and information processing, and the problem spaces that can occur. In relation to the results, the reality seems to be that designs for learning may adapt and include a variety of tools, combinations of modalities, levels of interactivity, learner characteristics, and pedagogy based on a complex set of circumstances (Fadel, 2008).

\section{Paper V, Conditions of Learning in Education Supported by Geovisual Analytics}

This last paper examines the interactions between data communication, task characteristics and primary schoolchildren's data use. The aim is to understand emerging learning conditions, ${ }^{29}$ with a focus on complexity, in primary schools social science education, when a

${ }^{29}$ The concept of learning conditions is elaborated on and explained on page 43-44. 
geovisual analytics' visual storytelling methods are employed. Also, this inquiry builds on empirical data from phase 3 (see page 58-64).

One important result presented in paper IV is that the learning activities were distinguished by a broad complexity emerging from the actants' deeply intertwined relations in the activities. In this paper the complexity was found to also involve different problem spaces. As the characters of the translations changed due to different aspects, the different problem spaces changed and in this way the complexity in the learning activities varied. The different problem spaces were mainly distributed by aspects as: task characteristics related to instruction/ discretion; the data type related to the area of focus and performer dependence linked to data use. Even though this complexity occurred, the students were usually able to analyse and understand the visible interactive information.

The visual educational material supported the students in their understanding of how relations between the learning content, the concepts and the graphics work, but the task of transforming the content (the knowledge) into another modality different from the one in which they encountered it seemed complicated to them. To certain degrees, the students' understanding of the visible information seemed not to get enough attention, and therefore there was too little focus to construct meaning from the information. In place of deepening their reasoning to make their thoughts clear, the students in this study focused on producing a product of their knowledge by written answers. This was consistently a task with which the students had difficulty, and they often had problems proceeding without support. As a result, their learning process was interrupted and whatever the students had learned together with the geovisual analytic tool was obscured and made inaccessible. Thus, the paper argues that novel approaches to teaching and learning could benefit students' knowledge formation as they work with and analyse visualized information and conclude by saying that visual analytics also requires constructive visual analytical reasoning, but also that the introduction of the tool raises many questions that are yet to be answered. 


\section{Conclusions}

The main results show that it is possible to introduce and customize a geovisual analytics tool for educational purposes and that the shape of this kind of visual storytelling technology is feasible for production, presentation and dissemination of visualized educational material relevant for compulsory school. The analysis also shows that it is possible for teachers to manage the visual storytelling methods and to, with relevance for their teaching in social science education, use their own customized educational material. It is revealed that the technology is usable for students. Students understand how to adjust the interactive functions and indicators, and how to use the tool to understand connections between statistical data.

Moreover, when visual storytelling technology interacts in schools, the learning conditions that arise in the social science classrooms are found to be complex. The analysis illustrates how teachers, students, technology, information, tasks, data types, classrooms, etc. together, in close relation, create these learning conditions. One hand the analysis shows that learning activities involving visual storytelling provide students with opportunities to handle vast amounts of data; support to take part in the learning activities, and help in achieving various educational purposes. On the other hand the analysis show that different problem spaces emerge in the learning activities and that these are commonly distributed by task characteristics related to instruction; data type related to the area of focus; and performer dependence linked to data use. Complications occur as the school assignments usually also demand that the pupils have to turn their analyses of the visualized information into another modality - to formulate them into written text.

Consequently, the shape of the visual storytelling can be understood as offering different and possibly enhanced options for information processing by teachers and students. At the same time, the learning activities can also be understood as a practice that doesn't meet a didactic design that connects to the interactions between the visual storytelling technology and the students in primary school. This will be the theme elaborated upon in the next and final chapter, which discusses the study's results. 


\section{Discussion}

By this study, it has been possible to understand how technology for visual storytelling can be shaped and used in relation to social science education in primary schools, and also how social dimensions, technical and other matters create emerging learning conditions in such educational settings. In this final chapter I will discuss the results in relation to the study's aim, in connection with the aspects motivating the study and also in relation to earlier research, to the visual learning environment, and to teachers and students.

\section{The Shape and Use of Visual Storytelling in Social Science Education - How Interactions Take Place}

According to the concluded papers in this study I claim that the technology for visual storytelling is operational for teachers use in their social science teaching. I assert also that the Vislets constructed by the teachers constitute an adequate learning environment for primary students (and others). I stress that the learning activities in the social science classroom including storytelling technology provide students with different kinds of opportunities, support and help. The students in the study seem to appreciate the learning process while using the Vislets. Moreover, the students point out that this kind of learning process differs from what they are used to. The results illustrate, as earlier highlighted, how all actants (teachers, students, technology, information, tasks, data types, classrooms etc), together, in close relation, create the conditions for learning in the studied social science classrooms. So, in other words, together the papers support an understanding of how all actants actually co-construct the learning conditions. These learning activities are assembled and they emerge as nodes in a network. In the networks of the studied classrooms, different problem spaces $^{30}$ emerge and characterize different aspects of the learning conditions (see Figure 11,).

\footnotetext{
30 The term 'problem space' refers to the kind of moments that can occur in a translation. It is those moments that take place before it has turned into a complete translation, if it succeeds in doing so at all. For further explanation of the concept, see page $40-41$ and paper $\mathrm{V}$.
} 


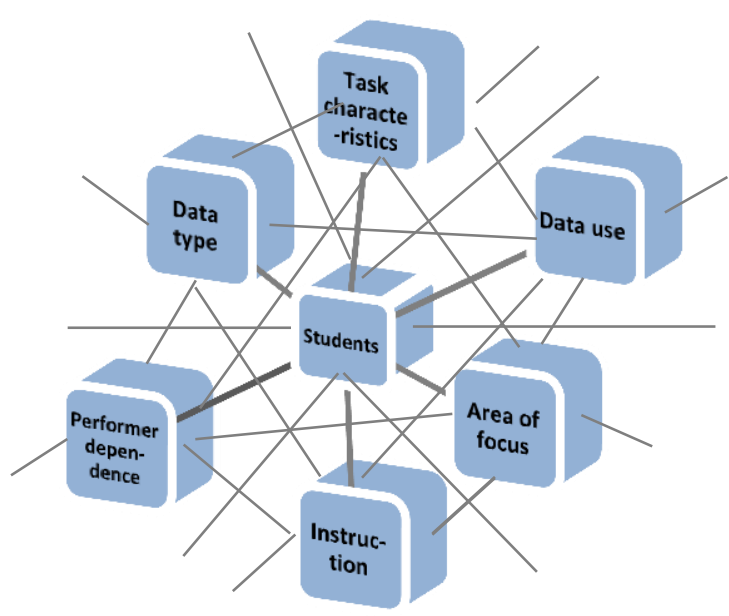

Figure 11, The learning activities in the classrooms (the actants' interactions, their alignments and translations) are assembled as nodes in a network. They go in all directions, also outside and beyond the factors underlined here. The problem spaces are mainly distributed in relation to the factors emphasized here.

These problem spaces were commonly distributed in relation to:

- task characteristics related to instruction/discretion,

- data type related to the area of focus, and

- performer dependence linked to data use.

It is important to note that the aspects do not appear as separate pairs and that they go outside and beyond the factors underlined here. To conclude, when the new technology was introduced in the studied educational setting, this affected the learning activities. This establishes the highly complex learning conditions which are demonstrated in this study. The technology can therefore not be seen as a neutral tool for the development and facilitation of teaching objectives and goals. It does not automatically lead to better education, even though I just claimed that the Vislets constructed by the teachers constitute an adequate learning environment for the students. Instead, one of the key implications of the study is that technology, in this case a geovisual analytics, is solely a catalyst for educational change. It is what the technology, the teachers, the learners, and other actants 
actually do that brings about change and eventual improvement of education and learning. The teachers can rather quickly, adopt and integrate the technology into their educational practice. But, without having time to reflect on the possible effects, consider didactics and adjust the teaching practices, the possibilities for educational development are limited (Lee, 2009). I assert this as the students in the study could handle the new learning environment, but they did not meet a practice that had taken into account the new conditions of learning that arose. Consequently, when scrutinizing the 'real state' of technology use in teaching and learning, there seems to be a discrepancy between the overall policy and the hopes for change. If any progress in education is going to take place, there is more to ask of the educational community as a whole. To pin the hopes for educational change (European Commission, 2008; OECD, 2009) only on the introduction of new digital technology seems unrealistic.

Accordingly, the following discussion will emphasize different aspects in relation to interaction between the learning conditions found in the social science classroom and the educational community.

\section{The Learning Conditions - Social Dimensions, Technical and Other Matters Matter}

The learning activities that took place and the learning conditions that arose when visual storytelling was interacting in the educational practice will be discussed in relation to different aspects of social science education. The first part of the discussion attends to knowledge formation that takes place in the studied classrooms in relation to the emerging learning conditions and educational culture at large. The discussion's second part tries to discern aspects from the emerged learning conditions on the didactic design, the teaching material, the visual stories and actions. The third and final section deals with qualities of knowledge asked for in education that employs visual technology. I also discuss these qualities in relation to the risk of a 'failing' education in a control and accountability education culture and the possibility of taking advantage of technology to support students' abilities and readiness to orient themselves and participate in a globalized information society. 


\section{Knowledge formation}

This study concerns contemporary information and the knowledge society with a focus on the challenges people face in sorting, filtering, interpreting, and evaluating huge quantities of information. It was emphasized in the introduction that the main problem was not finding information as such but laying one's hands on the relevant bits and putting them together. Also, the moves that have gained ground in this connection, namely, the transfer from the dominance of writing to a new dominance of images and a transfer from the medium of books to the medium of screens (Kress, 2010), were highlighted. So, what can this study tell about students' knowledge formation when they try to develop their abilities in an educational environment where these moves appear to be taking place? Can they find the knowledge that is lost in information? Can they find the wisdom that is lost in knowledge (Eliot, 1952)?

The students are able to handle the information-rich setting, as they were able to encounter and translate with the multimodal signs on the screen. If the Vislets' display of information is relevant to them, the interface's interactive features can be used for fact-finding (when information is needed just to find facts). But more important, the display can be used by students to analyse content in the course of completing wide-ranging tasks concerning different socio-scientific issues ${ }^{31}$ on national or global levels. Thus, with the help of the Vislets they are able to interact with information from large data sets. They can search for, find and analyse indicators that concern complex problems, and with the visualizations they are able to analyse these. They succeed in discovering patterns and drawing conclusions. In this way, the students are able to discuss complex assignments in the social science classes. The Vislets open up for activities that are interdisciplinary in character, which is an important feature of this subject according to, for example, Spanget Christensen (2013). In this case the information practices are characterized by interactions between the students and the Vislets, in which the students search, follow, and focus on the coded information that is articulated and highlighted by the Vislet. These actions seem to take advantage of young students' 'automatic' attraction to images and

${ }^{31}$ For definition, see footnote on page 7. 
selection-driven navigation (Adami \& Kress, 2010). The Vislets allow the students to first connect to and analyse the visualized content, then to investigate and decide what is important to them and to analyse these items further by zoom or filter functions and also to obtain details on demand (Andrienko et al., 2011).

So, in the learning activities the students go between reading the visualizations, reading the text, clicking on the different types of hyperlinks, and coming back again to zoom in on visualizations or read new images or texts at pre-selected websites. This is in line with van Leeuwen $(2005,2006)$, who describes this as 'silent reading.' The Vislet seems, in different degrees, to offer an environment for this. This is a way, also emphasized by Kress (2003), to move away from reading as interpretation to reading as a matter of imposing order and relevance onto what is presented to the students. So, if the students are offered relevant 'tailor-made' educational material, this supports the students' practice of reading as design (Kress, 2003). The Vislets guide or direct the students' reading and also allow them to take the initiative to read other sources. It is possible to assert that the students' information skills, vision, and competence are developed in close collaboration with the Vislets. The Vislets seem to supply the students with 'a knowledge of seeing and reading' that focuses the events visible on the screen. This leads them to translate with the object of knowledge, which in turn allows them to analyse and draw conclusions. In this case, as pointed out, the relation to students' prior knowledge of different first-, second- and third-order concepts is central in the process (Husbands et al., 2003; Spanget Christensen, 2013; Sandahl, 2011).

Also, alternative search strategies, options to copy-and-paste information, as well as benefits in source evaluation practices are found in relation to the students' and the Vislets' activities. It became evident that the copy-and-paste strategy that is commonly used by younger students (Lundh \& Limberg, 2008) could not be used in an ordinary way. Searching for suitable written material on the web is a task with which many students in these age groups struggle (Alexandersson \& Limberg, 2012; Alexandersson et al., 2007; Gärdén, 2010; Lundh \& Limberg, 2008). In their written assignments, students sometimes use 
sentences and paragraphs from texts they find on web pages and in online documents. However, the Vislet didn't offer already produced sentence(s) or full texts such as those commonly found online. The students often ended up with a screen that displayed several visualized articulations, where an 'option' for an answer was displayed. It was not a ready-made product in the form of sentences that could be copied or that could constitute and eventually make up an answer or work as a ready-made indicator of knowledge. The Vislets could therefore be used in order to avoid copy-and-paste strategies; as such strategies often correspond with poor learning outcomes (Limberg, 2005). The students could have taken a screen shot of the interface as a proof of their final interaction with the Vislet as an alternative copy strategy, but that kind of 'copy-strategy' would still entail further analysis by someone (the student), who would need to add words to explain the image. A lot of this depends, of course, on the kind of task that is posted to the students, and instructions on how to proceed with it.

Furthermore, as Johansson (2012) notes, this kind of information resource cannot draw upon traditional source evaluation criteria as it is almost impossible to make a critical assessment of a document's author or institution of origin. In this specific case there is a mix of resources from which the official data have been collected and the resources that the teachers decided to add in their visual storytelling, and the teacher as a resource produces a text included in the story (the teacher's name as author and school are always announced in each Vislet). Some of the responsibility for critical source evaluation as a first step can be said to be taken by the teacher, and that is probably an advantage for primary students. Otherwise an information search usually starts by using Google's search engine and then the students end up with thousands of sources to decide among (Kjällander, 2011). The Vislet can instead be seen as a safe starting point when learning on the web. This is something that the students need and is important to support, according to Fleischer (2013). However, the safe starting point that a Vislet can constitute doesn't exclude the need for students to have a critical discussion of the Vislets as an information source. The official statistics and the other information resources included in the Vislets were seldom discussed in the classrooms, nor were strategies for treating that information critically. Statistics can be misleading 
and there are several misrepresentative interpretations of statistics that can be made (Huff, 1954), even though the field of data visualization aims at present information that avoids creating misleading graphs (Beattie \& Jones, 2002; Tufte, 1983; 1997). However, my standpoint is that it is vital to develop a critical awareness in view of the large amounts of information available, the varying information sources, to statistics and the common anonymisation of authorship in web 2.0, and the increasing use of visualization tools, also highlighted by Johansson (2012).

However, the primary task for the students was not to evaluate information; it was to rapidly try to transform the visual information into text-based information which in turn also is a complex issue for younger students (Hermansson, 2013). By this manner the visible information did not seem to get enough attention. The students spent little time focusing on and constructing meaning from the visual information. Instead, they seemed anxious to quickly come up with a written answer to their task. There was seldom time, or so it seemed to the students, to first thoroughly discuss or in a deeper sense translate with the information and in turn to contemplate about what to write, This is interpreted as the students having learned what it is to 'do school', namely, to produce text products as signs of knowledge. The students' conviction of their need to produce text as signs of knowledge, and that this is what it means to be a student in school (Biesta, 2006; Edwards et al., 2009; Ludvigsen, 2012; Lundh, 2011; Winter \& Biesta, 2012), was so strong that the ability to make insightful and productive use of the Vislet in their class work was often reduced and also seemed in some sense to disappear. Hence, when the students used the analysing tools they did not translate with the visualizations fully. They processed only a few of the areas that Bruce $(1997,2000)$ points at as important to be information literate (see page 28). They did not seem to build up any deeper personal knowledge in the new area of interest. They did not seem to work with knowledge formation and personal perspectives adopted in such ways that novel insights were gained at a level where they could use the insights wisely for the benefit of themselves and others. Instead the students did what they thought was expected of them. They seemed stressed and performed 'just in time learning' to accomplish results, where knowledge 
formation is characterized by a focus on speed and did not emphasize understanding the information. This reproduction of information with or without gaining knowledge is also found by Krange \& Ludvigsen (2008) and Jedeskog \& Nissen (2004). I argue that deeper reflection is needed to create possibilities for 'deep' and not just 'shallow' knowledge. My standpoint is that the students have to be stimulated actively to collect and process information in different ways, which also Fleischer (2013) claims. That is in my opinion, as the didactic contract (Brousseau, 1997) was present to a great extent in the learning activities. It is clear that the rules of communication established in these educational settings had an impact on how the students learned to identify and use the different resources (Lundh, 2010). This is consistent with Alexandersson and Limberg (2012) and Alexandersson et al. (2007), who claim that even if this pattern is a known dilemma in educational practices and many teachers make a great effort to change the procedural approach, it is hard to change students' understanding of schoolwork. I assert, as Jones and Flannigan (2006) have also done, that it is important that students develop the ability to understand what is seen, to interpret what is experienced, to analyse what has been exposed, and to evaluate and make conclusions based on criteria that support critical thinking.

\section{Didactic design}

One of the main arguments underlined in the introductory chapter was that the information overload and the visual techniques developed to cope with all of that information also challenge education to emerge, develop methods and adapt new tools. Another argument was that when new technology is introduced in new settings, this often dramatically changes the way people work and it is hard to foresee the direction that will take (Applegate et al., 1990). So, what effect will the emerged learning conditions have when the technology introduced in this study is interacting in school? How did work change? In what direction did the changes go? What was required in relation to the didactic design of the teaching and the visual stories?

The visual storytelling methods seem to offer opportunities to customize the educational content into tailor-made interactive visualized 
teaching material that supports and helps students in their efforts to learn. The visual storytelling methods allow the teacher to achieve an 'omstilling' - a 'transposition' of the 'raw material' into concrete teaching material and actions (Ongstad, 2006; Sandahl, 2011). With the visual storytelling methods the teachers have an option to create a more framed social science education than usual, which is requested (Kjällander, 2011; Reynolds \& Vinterek, 2013). However, the visual storytelling methods also present many challenges to the teachers, placing severe demands on them. These include providing the students with educational material that is relevant, that presents a measured view of the world that is didactically designed in relation to the students' abilities and so forth. Ongstad (2006) argues that the choice of work model depends on the content of the educational situation and goals for the lesson. So, when deciding on didactic design of the lesson plans and the visual stories, many questions come into focus, such as: What promotes knowledge formation? What knowledge should be learned? How can the students reach the objectives by interacting with this material? What questions are to be asked of the students? How are the students going to come up with their answers? How is the knowledge to be measured? So the teachers' didactic knowledge of the subject is without question central to their visual storytelling and their teaching performed with Vislets in the classrooms.

However, the issue for the students is how to understand relations between the areas of focus: the learning content/the concepts and the data types; the graphics. What do the indicators indicate? How is the diagram going to be read? This appeared to be central to the learning activities in this study. The students need to understand first-order concepts (i.e. indicators such as population growth) and second-order concepts that may concern the data type (i.e. read the interactive diagram). So, a teacher has to reflect upon what concepts the students are familiar with, and what concepts are new. The teacher has to take into consideration the students' prior knowledge in relation to their firstand second-order concepts. I say that these two levels of concepts are important for enabling students take part in the learning activities that involve the visual technology. Husbands et al. (2003) argue as well that students need to grasp the vocabulary of these concepts levels in order to be linguistically competent. So, when deciding which content 
(indicators) to be included in a Vislet, the teachers not only have to put this in relation to the educational goals (i.e. conditions in nature and the environment for population and settlements, covering land, water and climate) and the knowledge domain that is going to be processed (e.g. countries' $\mathrm{CO}_{2}$ emissions, energy consumption, etc.), but they are also advised to do this in close relation to the students in question. If teachers are expected to be able to associate to and combine all these factors, their own domain-specific knowledge becomes critical. This is when they decide on indicators, when they are exploring the different indicators in the production phase of the visual storytelling and in their design of the story. In addition to this, their familiarity with useful information on the web also becomes important, as well as their level of critical information literacy. In this phase a high level of visual literacy is also desired of the teacher. Hence, the teacher is to produce a visualized story comprising relevant text, visuals and hyperlinks. What's going to be highlighted in the Vislet? How is it going to be accentuated? And what information is going to be found in other sources? The teachers' talent for bringing about 'silent' reading in their students becomes significant.

Furthermore, as the task characteristics were deeply intertwined with instruction/discretion, the teacher may think through what questions are going to be posted for the students in relation to the visualized story and what instructions are to be on the work model, etc. The students put a lot of effort into organizing their activity, interpreting their tasks and understanding the concepts that the task deals with (first- and second-order concepts), and as long as they have not sorted these out it seems that they cannot go on to process the information. So, again a teacher has to decide on the best way to design a visual story in relation to the students in question, the knowledge domain and the educational goals, etc. Moreover, the teachers might also take into account how the students are going to process the information in relation to their assignment. This has been emphasized as performer dependence, which, in this study, was shown to be commonly linked to data use. This study shows how the students were generally able, with support of the technology, to translate with the task, the domainspecific concept and the learning content and solve the task. After the interaction and translation phase the students could usually declare a 
solution verbally. But as explained earlier, when they had to transform their solution into a different modality, they often ran into difficulties. The requirement to complete the task by providing a written text as a solution of the educational assignment became a problem for the students, when the visual technology was put to use. This ability to discern aspects of a learning object from different types of media, acknowledging that using media in diverse ways produces different meanings and altered ways of action, is not usually taught at school (Fleischer, 2013) and may also be unknown to teachers. The teachers may balance performative, fast knowledge formation with a deeper, more reflective way to learn. When data visualization tools are interacting in school the didactic design has therefore to be adjusted to correspond with emerging learning conditions.

\section{Qualities of knowledge}

One starting point for this thesis was that society is changing rapidly, institutions are challenged and the lives of most children today are greatly affected by the proliferation of digital devices. These children both demand and desire efficient tools when trying to transform the information accessible all around into understanding and knowledge (Dunkel, 2007). What do they need in this 21 st century and how can it be given to them (Prensky, 2012)?

I have suggested that the students in this study did not meet adequate conditions of learning. This was the case even though the studied educational practice tried to support the students' learning processes by offering powerful tools that were intended to reinforce their analytical reasoning, argumentation and knowledge building. This was the circumstance even though the students were able to manipulate the technology and take advantage of the visualizations and the analytical features. In its place, this study determines that the students' learning activities with the visual analytical technology did not meet a didactic design or practice that connected to them. This is also showed at the country level; access to digital technologies in Swedish schools is better than ever, but when it comes to working with planned, didactically designed education that includes the use of digital technology Sweden falls in the rankings compared to other European countries 
(OECD, 2014; Swedish National Education Agency, 2013; Swedish Schools Inspectorate, 2011). But can the teachers be blamed for this? I argue that it is not possible to put the responsibility for the loss of a school practice that is designed in a didactically relevant way in relation to technology only on them. The shortcomings cannot be reduced to individual factors or to social categories such as teachers, headmasters, and teaching education trainers, nor to specific reforms or ideologies (Martinsson \& Reimers, forthcoming). Instead, my view is that the emerged learning conditions appear in a clash between the paradigm of communicating information using visualization and information access at interactive screens and the paradigm of education that takes place in a culture of control and accountability. The school practice in such an education culture easily develops into a place that is driven by a desire (or a pressure) to be better than others (Apple et al., 2005). The control mechanisms used in such practice, in relation to the educational goals, are linked to measures of school quality and international comparison (Martinsson \& Reimers, forthcoming).

Due to the results in this study I question whether this education culture, by performance-conducive incentives through competition, autonomy, and accountability, stands as a good way of improving students' educational achievement (Wößmann, 2007). Instead, I would argue that the social science classrooms where this study took place as institutional spaces of formal schooling - are in fact suffering from this. The impact of this culture on the day-to-day practice seems to adapt requirements of accountability and audit, rather than to encourage, professional and responsible action (Biesta, 2004). Instead, it becomes increasingly challenging for teachers to act according to their professional judgment and apparent needs of the learner (Biesta, 2004). The practice threatens instead to develop with a focus on knowledge and procedures that result in knowledge that can be quantified. There is a danger that questions that are asked are unproblematized questions, where answers are easy to find and easy to write down and assess. So, a safe way to control the practice and learning is to ask students to accomplish tasks and to prove their knowledge by providing written answers (Winter \& Biesta, 2012). This is what happened in this study; the students were asked to fulfil their assignments in written form. But in this case, when using the novel 
technology they became unsuccessful when working in this manner. This is in line with PISA 2012 (OECD, 2014), which shows as a paradox in this discussion on accountability, how Swedish students performed better on 'static' problem solving assignments than on interactive and complex ones. The way 'proof' of knowledge, in the classrooms in this study was measured was not adjusted to a learning environment that considered the impact of the digital tools something Fleischer (2013) also demonstrates. This study shows how this practice leads to shortcomings in knowledge formation and results in an interrupted learning process and shallower knowledge. If education allows what seems to be needed - a deeper interaction with the visualized content and fostering of a reasoning practice when the students try to complete their assignments - there is a risk that the teachers will at the same time give up control and accountability in the classrooms. Audio, speech, and discussions are not easily grasped and seldom counted as evidence of knowledge. The results therefore lead me to conclude that there are limited possibilities to taking advantage of the visual analytical reasoning technology to support students' abilities and readiness to participate in a globalized information society, at least as long as knowledge has to be controlled and accounttable as discussed - that is, as long as text production remains the dominant mode of demonstrating and confirming the acquisition of knowledge.

The paradox is, that the teachers who might take a risk and be willing to 'fail' in this kind of education culture may instead allow their students to succeed in solving complex assignments by manipulating extensive masses of information that are available to be analysed. These teachers may help their students develop other types of knowledge and abilities. They may be the ones who support students' abilities and readiness to participate in a globalized information society.

The learning activities and learning conditions established in the social science classrooms when visual storytelling interact call for alternative ways to view qualities of knowledge and organization of social science education. I argue that talk, reasoning, interpretation and discussion are valuable and should be given a higher value in school. I claim that time 
permitted for reasoning that is vague and ambiguous and does not result in straightforward answers is necessary for students' knowledge building - especially in relation to a complex world, the masses of information available, the extensive information sources and work including analyses, conclusion and decision making. The verbal dialogue in relation to visual technology can support children in the digital era as they learn about the world and create their apprehensions. This is important as the world shown really seems to be interpreted differently than the world told.

The findings in this study concerning the complex learning conditions, when visual storytelling interacts in school, underline the importance of a knowledge formation directed at the knowledge content of the task and not at technicalities, order and procedures in the work. The didactic design may not focus only at seeking information and the use of various search tools and technologies to find the 'right answers' and deliver them as 'text products'. Instead it may be more fruitful if the interactions would be directed at aspects of using information, with a special emphasis on the construction of meaning from information. In these ways can visual storytelling be a catalyst for an educational progress. But, the practice requires then information treatment that includes time for not only visual interactions, but also nurture analytical reasoning. The possibilities to take the step from a quality of knowledge as threshold knowledge to generate profound understandings would probably gain from such a change. This would feature problem solving - and knowledge from where the students' worldviews may germinate.

\section{Future Research}

There are several areas that I think ought to be scrutinized further in relation to visual storytelling and social science education. In my view, interesting areas for future research include a closer focus on teachers' views of education involving geovisual analytics and visual storytelling. Important is to develop deeper understanding of their transposition of 'raw material' in relation to visual storytelling. Are there any imperative for teachers' production of visual educational material and the creation of 'silent texts'? A key would be to 
investigate, with help of e.g. eye-tracking, what 'silent' is to the students and how 'reading as design' affect the information strategies and the knowledge formation. Another interesting area to further investigate is different actants' (teachers, students and the technology) use of first-, second- and third-order concepts in relation to the visual storytelling methods and social science education. How do these concepts and the actants correspond to each other? As this study show the importance of adding analytical reasoning with visual analysis it becomes also significant to examine how social science education involving visual storytelling may foster reasoning practices in the classrooms. Central to this is as well, to find out more about how 'signs of knowledge' can be produced differently when students are working with complex information rich material through data visualization, without reducing the analysis to an over simplified text product.

I argue that it is important to develop the insights further about visual storytelling technology as my argument has been throughout this study that in this digital era, one task is to support children as they develop an understanding of the complex world of today and to prepare them for a rather uncertain world of tomorrow. This thesis has put some light on how to teach today's students, what these students need and how it can be provided. Let the following belong to the past!

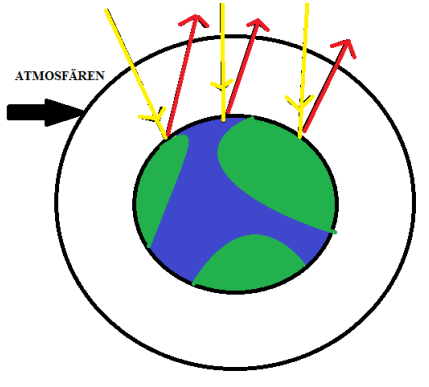

The OHP is turned on. At the transparent picture the world is visualized, a line is symbolizing the atmosphere and arrows are jumping up and down from the face of the earth. I sigh, quiet and discrete; it is the fifth time during my school years that the teacher elegantly draws this same image in front of my nose tip.

The issue is treated practically the same every time, some explanations; some fear of judgement day; some energy alternatives and then simplified suggestions for solutions like: use water-efficient showerheads and remember to turn the light off that your parents 
forgot to switch off! Why must education simplify the content and issues of the world?

At the same time the climate meeting in Copenhagen ${ }^{32}$ is at full speed. The issues that these world politics are discussing are difficult for me to understand. I don't have grounded knowledge of what countries that combust the most $\mathrm{CO}^{2}$ per capita or which countries that suffer greatest from this. I have to guess upon fundamental knowledge like this from thousands of sources that not seldom, are contradictory or not possible to read.

So, I beg all teachers to broaden the education to also include issues on globalisation, nations, companies' and organisations' roles in society as well as economic issues. We understand more than you think and we have to get 'buildung', to be united and targetoriented, from that real change can come.

Text written by a young student in Ung NT, 2009-12-17,

(translation by author).

This letter to the press was one of the starting points for this work. Hopefully, may now data visualization tools and this contribution support some of the circumstances for learning in school. With this I close this comprehensive part of the study. In the next chapter a summary in Swedish is offered. Thereafter, in part B, the five different papers that compose this study are attached.

\footnotetext{
32 The Copenhagen Climate Change Conference - December 2009, organized by the United Nations between $7^{\text {th }}$ and $18^{\text {th }}$ December 2009. At the conference over 15000 delegates from 192 countries participated. The conference main goal was to unite the delegates around measures to be taken to prevent global warming.
} 


\section{Svensk sammanfattning}

Utgångspunkten för denna avhandling är den nära koppling som finns mellan utbildning, information och teknik. I avhandling undersöks relationerna mellan dessa aktörer och elevers kunskapsbildning. I centrum ställs de villkor för lärande som uppstår i samhällsorienterande ämnen där teknik för visuell bearbetning av information introduceras.

En av de utmaningar som dagens informations- och kunskapssamhälle har att hantera, handlar om produktionen av och tillgängligheten till gigantiska mängder information. En orsak till uppkomsten av detta överflöd av information är utvecklingen av informations- och kommunikationsteknik (IKT). Tekniken bidrar inte enbart till att mängden av data ökat, den innebär också att information blivit mer tillgänglig än tidigare. Informationen brusar mot oss, i ett ständigt pågående flöde. I detta samhälle utmanas människan till att ständigt sortera, filtrera, tolka och utvärdera stora mängder information (se till exempel: Hilbert \& López, 2011; Mayer-Schönberger \& Cukier, 2013; Ohlhorst, 2013). Denna uppgift är komplex och informationsmassorna tycks även skapa en diffus eller vag bild av världen, där kunskap blir något svårfångat och insikt svår att nå. Uppfattningen av dagens globala värld har också många gånger blivit en skev bild av verkligheten, en bild som inte alltid stämmer med den information om världen som egentligen finns tillgänglig (Rosling, 2004; UNDP, 2007). Detta utgör förstås en paradox. Vi har tillgång till information, men på grund av den stora informationsmängden klarar vi ofta inte av att tolka och analysera den. Därför, även om mänsklig kommunikation alltid har använt olika kommunikationskanaler, så undersöks nya sätt att länka ihop, överföra eller koppla samman de allt mer komplexa och i volym tilltagande informationsmängderna.

I anslutning till de ökande informationsmassorna kan två pågående skiften urskiljas. De handlar om hur information 1) produceras och 2) kommuniceras. Det första skiftet är ett skifte från skrivande som den dominerande uttrycksformen, till bilden. Det andra skiftet handlar om 
att boken alltmer överges som det dominerande mediet till förmån för skärmen. Dessa skiften hänger samman med teknikutvecklingen som spänner vitt, allt ifrån IKT, till visualiseringsteknik, informationsvisualiseringsteknik, visuell analysteknik, geovisuell analysteknik, etc. Att använda visualisering för kommunikation av information är dock inget nytt utan har ända sedan grottmålningarnas tid använts för detta ändamål. Numer har vi tillgång till högteknologiskt databaserade interaktiva visualiseringar. Den kombinerade effekten av de två skiftena, från skrift till bild och från bok till skärm, skapar förändringar i människans sätt att lära och uppfatta världen (Rosling, 2007; Kress, 2010).

En annan konsekvens av informationsöverflödet är ökande krav från samhället sida, i förhållande till vad alla förväntas lära och klara av. Ludvidgsen (2012), menar att elever, i alla åldrar, idag förväntas att hantera mer information och utveckla fler förmågor samt utveckla en större mängd kunskap än tidigare. De ska skapa färdigheter som ger dem möjligheter att orientera sig i ett samhälle som är mer komplext än någonsin. Detta inkluderar olika typer av problemlösande uppgifter både $\mathrm{i}$ och utanför skolan. Sammantaget utgör detta stora utmaningar för skolan, där både lärare och elever befinner sig $\mathrm{i}$ en intrikat situation: större informationsmängder skall hanteras samtidigt som de pågående skiftena angående informationshantering förändrar sättet att både berätta om världen, men också sättet att lära och förstå världen. Detta skapar grund för många intressanta forskningsfrågor.

I denna studie introduceras en tämligen ny sorts teknik, geovisual analytics (GVA). Detta är också ett forskningsfält som utvecklar dessa verktyg vilka syftar till att ge möjlighet att analysera stora datamängder i anslutning till visuellt berättande. I studien introduceras ett sådant verktyg, the 'Statistics eXplorer platform.' Detta verktyg erbjuder metoder för att importera stora mängder officiell statistikdata ifrån olika databaser och omvandla dessa data till visualiseringar. Lärare erbjuds av denna teknik att välja olika ämnesrelaterade indikatorer i relation till centralt innehåll i läroplanen, undersöka dessa faktorer, skapa en berättelse om dessa som innehåller visualiseringar, textbeskrivningar, samt olika interaktiva funktioner. Detta kallas för 'visual storytelling.' Berättelsen kan sedan publiceras av lärarna på en 
websida eller en blogg och kallas då för Vislet, vilken då också blir åtkomlig för eleverna.

Studien syftar till kunskap om hur teknik för visual storytelling kan vara utformad och användas i relation till undervisning i samhällsorienterande ämnen i grundskolan (årskurs 4 - 6), men också hur sociala dimensioner, tekniska och andra faktorer tillsammans skapar villkor för lärande i denna typ av undervisningssammanhang. Mer specifikt formuleras följande tre forskningsfrågor:

- Hur kan teknik för visual storytelling vara utformad och användas med relevans för lärares undervisning i samhällsorienterande ämnen?

- Hur kan Vislets, som ett specifikt undervisningsmaterial vara användbart för elever i samhällsorienterande ämnen?

- Hur konstrueras lärandevillkor i samhällsorienterande ämnen när teknik för visual storytelling används?

Studien genomförs inom ramen för pedagogiskt arbete, och dess interdisciplinära (tvärvetenskapliga) karaktär förstärks av att den till delar realiseras tillsammans med forskare inom GVA, aktiva vid Nationellt Centrum för Visuell Analys (NCVA). ${ }^{33}$

Grundläggande antaganden för de teoretiska perspektiv som används i studien handlar om att världen ses som en social konstruktion (Berger \& Luckmann, 1967). Två olika teorier används för att besvara studiens syfte och olika frågeställningar. Ett sociokulturellt perspektiv används för att besvara de två första forskningsfrågorna. Social aktivitet, kontext, interaktion, mediering utgör centrala begrepp i detta perspektiv (Vygotsky, 1986; Wertsch, 1998). Aktör-nätverksteori (ANT), används för att besvara den tredje forskningsfrågan eftersom denna teori möjliggör att utgå från och analysera både människa och materialitet. Viktiga termer utgörs av: mänskliga och icke-mänskliga aktörer, nät-

\footnotetext{
${ }^{33}$ NCVA är Svensk nationell resurs och mötesplats som grundades genom KKStiftelsen, VINNOVA, SSF, ISA och Vårdalstiftelsen. NCVA syftar till att sprida geovisual and visual analytics teknik till industrin samt statliga och kommunala myndigheter.
} 
verk, interaktion och översättningar (Latour \& Woolgar, 1985; Callon 1986; Law, 1987; Ashmore 1993; Latour, 2005; Hultman, 2011). I studien förstås lärandevillkor som något som uppstår genom eller konstrueras av alla aktörers (både mänskliga och icke-mänskliga) interaktioner. Det betyder att de handliga som blir möjliga att utföra inte utförs under etablerade villkor i en social kontext utan utgångspunkten i studien är att det är alla aktörers möjliga handlingar som tillsammans konstruerar lärandevillkoren.

I studien ses samhällsorienterande ämnen (So) ur ett brett perspektiv, vilket också innebär ett interdisciplinärt synsätt på dessa skolämnen. Intentionen i undervisning av dessa ämnen har ofta associerats med aspekter så som utveckling av elevers synsätt på världen, lag och rätt, medborgarskap samt tillväxt av elevers förmågor att exempelvis söka och utvärdera information, argumentera och kritiskt tänkande (Barrue \& Albe, 2011). För att utveckla dessa kunskaper och förmågor sätts eleverna ofta att lösa olika typer av samhälls- och naturvenskapliga frågor så kallade "socio-scientific issues"34 (Lauder, Brown, Dillabough \& Halsey, 2006; Sadler, 2009).

\section{Empiriskt material}

Det empiriska materialet är insamlat under tre olika faser, som var och en bidragit till besvarandet av en särskild forskningsfråga.

Fas 1: Visual storytelling-teknik i relation till undervisning $i$ samhällsorienterande ämnen, syftade till att besvara den första forskningsfrågan. Data genererades när 16 lärare i So, blev introducerade till tekniken och utbildade (sex tillfällen) i metoder för visual storytelling. Data i denna fas utgörs av fältanteckningar från sex utbildningstillfällen och 2 stycken fokusgruppsintervjuer. Materialet analyserades med fokus på lärarna - med hjälp av ett sociokulturellt perspektiv. Resultatet ifrån denna fas - att verktyget kunde utformas och användas

\footnotetext{
${ }^{34}$ En så kallad "socio- scientific issue" är en fråga som ofta anses ta sitt ursprung i naturvetenskap men har potential att påverka samhället. De kan ha påverkan på både individer och grupper på olika nivåer, från att handla om lagstiftning till individuellt beslutsfattande och medborgaransvar.
} 
med relevans för lärares undervisning i So-ämnen - gjorde det möjligt att initiera den andra fasen av studien.

Fas 2: Visual storytelling-teknikens användbarhet $i$ relation till elevers lärande $i$ samhällsorienterande ämnen, syftade till att besvara den andra forskningsfrågan. Data genererades av en usability study ${ }^{35}$ utförd $i$ en grundskola, där en lärare och dennes klass i samhällskunskap, 28 elever i årskurs 6 deltog. Elevenkät, "thinkaloud" intervjuer och videoobservationer utgjorde instrument för genereringen av data. Materialet analyserades med fokus på eleverna - ur ett sociokulturellt perspektiv. Med resultatet ifrån denna fas - att Vislets, som ett specifikt undervisningsmaterial, är användbart för elever i samhällsorienterad undervisning - så kunde den sista fasen inledas.

Fas 3: Lärandevillkor $i$ samhällsorienterande undervisningen när visual storytelling teknik interagerar, syftade till att besvara den tredje forskningsfrågan. Data genererades i tre olika grundskolor, i fyra olika klassers undervisning i samhällsorienterande ämnen. 98 elever och fyra lärare deltog i studien. Materialet producerades under samtliga Solektioner inom en tidsperiod på $2-4$ veckor på respektive skola. Det gjordes med hjälp av två olika typer av videoobservationer: a) med hjälp av en vanlig videokamera som spelade in så mycket som möjligt av klassrummet för att skapa överblick och b) med hjälp av mjukvara (TechSmith Corporation (n.d.) som fångade vad som hände på skärmen samtidigt som eleverna filmades med hjälp av datorns webbkamera och ljudet togs upp med hjälp av datorns mikrofoner. Detaljerade inspelningar av interaktioner mellan elever, tekniken, informationen, undervisningens innehåll, etc. skapades på så sätt. Materialet analyserades med fokus på samtliga aktörer ur ett ANT-perspektiv.

\section{Resultat}

Resultaten visar att komplexa villkor för lärande skapas, där visual storytelling-teknik interagerar i skolans samhällorienterande undervisning. Dessa villkor uppstår genom de interaktioner och det nära sam-

\footnotetext{
35 Översatt till svenska blir usability-study, en typ av studie som undersöker en tekniks användbarhet (inte bara teknikens användning).
} 
arbete som skapas av alla inblandade aktörer, som förutom visual storytelling tekniken, till exempel: elever, lärare, undervisningsmaterial, dator, skärm, symboler etc. Som tidigare nämnts, så visar resultaten att det är möjligt att introducera och anpassa ett geovisual analytics (verktyg) till lärares undervisning i dessa ämnen. Studien visar att användning av teknik för visual storytelling i form av produktion, presentation och spridning av visuellt och interaktivt undervisningsmaterial är relevant för so-undervisning i grundskolan. Lärare kan använda dessa metoder för att organisera ett undervisningsmaterial i förhållande till centralt innehåll i läroplanen och sedan nyttja det i sin undervisning. Resultaten visar dessutom, som pekats på, att det är möjligt för elever att använda det visuella och interaktiva undervisningsmaterialet. De hanterar de interaktiva funktionerna och de statistiska indikatorerna på ett tillämpligt sätt. Eleverna klarar att förstå samband mellan informationen och den grafiska semiotiken. Tekniken kan därför sägas utgöra en relevant lärmiljö för dessa elever (och andra). Dessa elever verkar uppskatta de läraktiviteter som uppstår tillsammans med denna typ av undervisningsmaterial (Vislets). De menar, att denna process för lärande skiljer sig ifrån den de är van vid.

Resultaten visar vidare, att de läraktiviteter som uppstår i denna typ av samhällsorienterade undervisning erbjuder elever: möjligheter att hantera stora data-mängder, support att bli delaktiga i olika läraktiviteter, men också hjälp att uppnå olika typer av utbildningsmål men även andra elevrelaterade mål. Däremot är läraktiviteterna som uppstår komplexa, då de olika aktörerna interagerar. Dessa kan ses bilda ett nätverk av relationer, vilka uppstår när de olika aktörerna möts, interagerar och samlas som olika noder. I detta nätverk uppstår också olika typer av så kallade problem spaces. Dessa karaktäriseras av olika aspekter som framkommer i de olika läraktiviteterna som: uppgifternas utformning, instruktionerna, data typerna, undervisningens innehållsmässiga fokus, elevers utgångspunkter samt data användningen. Studien visar också att den visuella informationen på skärmen, sällan får tillräcklig uppmärksamhet av eleverna. Alltför lite fokus sätts på att analysera den visuella informationen för att klara att utveckla djupare förståelse och väl genomtänkta slutsatser angående innehållet. I stället för att eleverna fördjupar sina resonemang så fokuserar de på att snabbt försöka formulera skriftliga svar på uppgifterna. Detta var 
något som genomgående visade sig vara problematiskt för eleverna. Detta ofta stressade arbetssätt, att så snart som möjligt formulera skriftliga svar, gjorde att läraktiviteterna gång på gång avbröts. Trots att eleverna klarat av att analysera informationen på skärmen, så stördes försåtelsen av ambitionen att omgående översätta det som de kommit fram till, till text. Denna inställning och skrivaktiviteten bidrog till att elevernas slutsatser ofta 'gled undan' och förståelsen som de uppnått med hjälp av visualiseringarna på skärmen 'tappades bort.'

\section{Diskussion}

I ljuset av de lärandevillkor som framkommer i studien, och den utbildningskultur som råder i övrigt, framstår den kunskapsformering som pågår i de studerade klassrummen som central att diskutera. På många sätt erbjuder tekniken möjligheter för eleverna $i$ deras formering av kunskap och de lyckas i stor utsträckning att ta vara på dessa. De kan med hjälp av interaktion med visualiseringarna beskriva sin analys och vad de kommit fram till i ord. Tekniken kan för eleverna skapa angelägna möjligheter att bearbeta stora informationsmängder och bidra till att utveckla deras olika förmågor. Eleverna möter dock en undervisningspraktik, som ännu inte är anpassad till den visuella analystekniken. Rättare sagt, eleverna har lärt sig vad det är att 'göra skola', att snabbt producera textprodukter som tecken på kunskap oavsett om det förstått eller lärt något eller ej (Krange \& Ludvigsen, 2008). Detta påverkar kunskapsformeringen i de studerade klassrummen, som i många fall blir avbruten när den visuella informationen på skärmen skall omformas. Att skriva är i sig en komplex process: bokstäver skall formeras, bokstäver skall bilda ord, ord skall stavas rätt, ord ska sättas samman till meningar, överväganden skall göras om vilka ord som skall konsturera ett bestämt innehåll (Hermansson, 2013). Dessutom ska texten, som i hast eventuellt produceras, beskriva slutsatsen av en analys som eleverna just snuddat vid. Denna översättning av visualisering till text, har visat sig vara en komplicerad uppgift för eleverna i studien. Den visuella lärmiljön skapar på så sätt förändrade förutsättningar för både lärare och elever vilka framstår som viktiga utgångspunkter för överväganden angående undervisningens didaktiska design. Synen på kunskapens kvaliteter blir en väsentlig faktor att ta hänsyn till då undervisning involverar visuell 
analys teknik. Min ståndpunkt är att de lärandevillkor som beskrivs uppstår i en krock mellan paradigmen att kommunicera information via visualiseringar och tillgång till interaktiv information via skärmgränssnitt och rådande utbildningsparadigm där en kultur av kontroll, mätning och bedömning råder. Detta handlar också om det dominerande sättet att visa kunskap handlar om textproduktion. Sammantaget så hotar dessa praktiker att främja en undervisning som fokuserar på kunskap och på procedurer som är möjlig att mäta. Min slutsats blir, att så länge kunskap måste kontrolleras i den utstäckning och på det sätt som görs idag, så finns det små möjligheter att dra nytta av den visuella analys tekniken, för att utveckla elevers förmåga orientera sig $\mathrm{i}$ det globaliserade informationssamhället.

Tal, resonemang, muntlig tolkning och diskussioner är värdefulla och behöver värderas annorlunda i skolan jämfört med idag. Att avsätta tid för formering av kunskap som tillåter vaga och ambivalenta resonemang blir viktigt. Tid för samtal som inte direkt leder till ett begränsat, smalt definierat svar som snabbt kan skrivas ner kan bli avgörande för elevernas kunskapskvalitet. Detta är viktigt, särskilt $i$ relation till vår komplexa värld, de tillgängliga informationsmassorna, de många källorna och arbete som innefattar analys, slutsatser och så småningom beslutsfattande. Därför bör inte undervisning och lärande enbart fokuseras på att söka efter information, att använda olika sökverktyg för att finna det "rätta" svaret och leverera dessa som textprodukter. Istället bör fokus ligga på olika aspekter av att använda information, med en särskild emfas på konstruerandet av innehållsmässig mening. På detta sätt kan en undervisningspraktik uppstå som tillåter och inkluderar visuell teknik och analytiska resonemang. På detta sätt kan några av utbildningens utmaningar mötas och elever kan få utvecklade möjligheter att interagera, lära, och förstå världen. Detta händer dock inte av sig självt, enbart genom att introducera ny teknik i skolan. Det är viktigt att komma ihåg, att när visual storytelling interagerar i skolan så uppstår komplexa lärandevillkor. Den här studien visar att visual storytelling teknik erbjuder möjligheter för elevers analytiska resonemang och kan bidra till att utforma undervisningen i samhällsorienterande ämnen annorlunda. Det är vad som görs tillsammans med tekniken i förhållande till didaktisk design och elevers kunskapsformering som blir betydelsefullt för kunskapens kvalitet. 


\section{References}

Adami, E. \& Kress, G. (2010). The social semiotics of convergent mobile devices: New forms of composition and the transformation of habitus. In G. Kress (Ed.), Multimodality. A social semiotic to contemporary communication (pp. 184-197). London: Routledge.

Ainsworth, S. (2008). How should we evaluate multimedia learning environments? In J. Rouet, R. Lowe \& W. Schnotz (Eds.). Understanding multimedia documents (pp. 249-265). New York: Springer US.

Alexandersson, M. (2002). Fingrar som tänker och tankar som blänker - om barns kommunikation vid datorn. In Säljö, R. \& Linderoth, J. (Eds.), Utm@ningar och e-frestelser. it och skolans lärkultur (pp. 147-165). Stockholm: Bokförlaget Prisma.

Alexandersson, M., \& Limberg, L. (2003). Constructing meaning through information artefacts. The New Review of Information Behaviour Research, 4(1), 17-30.

Alexandersson, M., \& Limberg, L. (2012). Conditions for information use and learning in Swedish schools: A synthesis of research. HumanIT, 11(2), 131-154.

Alexandersson, M., Limberg, L., Lantz-Andersson, A., \& Kylemark, M. (2007). Textflytt och sökslump - informationssökning via skolbibliotek [electronic resource] Stockholm: Myndigheten för skolutveckling.

Alvesson, M., \& Sköldberg, K. (2008). Tolkning och reflektion: Vetenskapsfilosofi och kvalitativ metod (2, [uppdaterade] uppl.). Lund: Studentlitteratur.

Andrienko, G., Andrienko, N., Demsar, U., Dransch, D., Dykes, J., Fabrikant, S. R., et al. (2010). Space, time and visual analytics. International Journal of Geographical Information Science, 24(10), 1577-1600.

Andrienko, G., Andrienko, N., Jankowski, P., Keim, D., Kraak, M., MacEachren, A., et al. (2007). Geovisual analytics for spatial decision support: Setting the research agenda. International Journal of Geographical Information Science, 21(8), 839857.

Andrienko, G., Andrienko, N., Keim, D., MacEachren, A. M., \& Wrobel, S. (2011). Challenging problems of geospatial visual analytics. Journal of Visual Languages \& Computing, 22(4), 251-256.

Apple, M. W., Kenway, J., \& Singh, M. (2005). Globalizing education: Perspectives from above and below. In M. W. Apple, J. Kenway \& M. Singh (Eds.), Globalizing education: Policies, pedagogies, \& politics (pp. 1-30). New York: P. Lang.

Applegate, L. M., Cash, J. I., \& Mills, D. Q. (1990). Information technology and tomorrow's manager. In W. G. McGowan (Ed.), Revolution in real time: Managing information technology in the 1990s (pp. 33-48). Boston: HBS Press.

Ashmore, M. (1993). Behaviour modification of a catflap: A contribution to the sociology of things. Kennis En Methode, 17, 214-229.

Auletta, K. (Ed.). (2009). Googled: The end of the world as we know it. London: Virgin Books. 
Avgerinou, M., \& Ericson, J. (1997). A review of the concept of visual literacy. British Journal of Educational Technology, 28, 280-291.

Avgerinou, M. D., \& Pettersson, R. (2011). Toward a cohesive theory of visual literacy. Journal of Visual Literacy, Vol. 30(2), 1-19.

Bailey, C. A. (2007). A guide to qualitative field research (2nd. ed.). Thousand Oaks, CA.: Pine Forge Press.

Bamford, A. (2003). The visual literacy white paper. A report commissioned for Adobe Systems Pty Ltd. Australia: Adobe Systems Pty Ltd.

Barad, K. (2007). Meeting the universe halfway. Quantum physics and the entanglement of matter and meaning. Durham, NC; London: Duke University Press, 2007.

Barrett, M. D. (2003). Children's knowledge, beliefs and feelings about nations and national groups. Hove: Psychology Press.

Barrue, C., \& Albe, V. (2011). New approach in French middle school: A possible congruence between SSI and citizenship education. Science Learning and Citizenship Proceedings of the ESERA 2011 Conference, Strand 7: Scientific Literacy and Socio Scientific Issues, 7, 11-16.

Bennett, J. (2010). Vibrant matter: A political ecology of things. Durham, NC: Duke University Press.

Berger, P. L., \& Luckmann, T. (1967). The social construction of reality: a treatise in the sociology of knowledge. Peter L. Berger and Thomas Luckmann. New York: Anchor books, 1967.

Bergqvist, K. (2001). Discourse and classroom practices: Reflectivity and responsibility in learning and instruction. Nordisk Pedagogik, 21, 82-91.

Beattie, V., \& Jones, M. J. (2002). Measurement distortion of graphs in corporate reports: an experimental study". Accounting, Auditing \& Accountability Journal 15(4), 546-564.

Bevan, N. (1995). Measuring usability as quality of use. Journal of Software Quality, (4), 115-140.

Biesta, G. J. J. (2004). Against learning: Reclaiming a language for education in an age of learning. Nordisk Pedagogik, 23, 70-82.

Biesta, G. (2006). Beyond learning: Democratic education for a human future. Boulder: Paradigm Publishers.

Bijker, W. E. (2010). How is technology made? That is the question. Cambridge Journal of Economics, 34(1), 63-76.

Bjessmo, L. (1990). Samhällskunskapen i gymnasieskolan: Om samhällsstudier i förändring. Häften för didaktiska studier. (pp. 20-21). Stockholm: HLS förlag.

Boström, E. (2011). Projektarbete i gymnasiet: Samtal, skrivande och institutionella förväntningar. (Lic, Göteborgs universitet, Institutionen för svenska språket).

Broadbent, D (1958). Perception and Communication. London: Pergamon Press.

Bronäs, A., \& Selander, S. (2002). Samhällskunskap som skolämne. In B. Falkevall, \& S. Selander (Eds.), Skolämne i kris? (pp. 75-82.). Stockholm: Stockholm Library of Curriculum Studies, Stockholm: HLS Förlag.

Brousseau, G. (1997). Theory of didactical situations in mathematics 1970-1990. [Théorie des situations didactiques.], Eds. M. Cooper, N. Balacheff, R. 
Sutherland \& V. Warfield Trans. Dodrecht, The Netherlands: Kluwer Academic Publishers.

Bruce, C. (1997). The seven faces of information literacy. Adelaide: Auslib Press.

Bruce, B. (2000). Credibility of the web: Why we need dialectical reading. Journal of Philosophy of Education, 34(1), 97-109.

Bruner, J. S. (1974). The growth of mind. In J. M. Anglin (Ed.), Beyond the information given: Studies in the psychology of knowing. London: Allen \& Unwin.

Bryman, A. (2011). Samhällsvetenskapliga metoder (B. Nilsson Trans.). (2nd. ed.). Malmö: Liber.

Burr, V. (2003). Social constructionism. (2nd. ed.). London: Routledge.

Butcher, K. R. (2006). Learning from text with diagrams: Promoting mental model development and inference generation. Journal of Educational Psychology, 98, 182-197.

Callon, M. (1986). Some elements of a sociology of translation: Domestication of the scallops and the fishermen of St Brieuc Bay. In J. Law (Ed.), Power, action, and belief: A new sociology of knowledge (pp. 196-233). London: Routledge \& Kegan Paul.

Callon, M., Law, J., \& Rip, A. (1986). Mapping the dynamics of science and technology: Sociology of science in the real world. London: Macmillan.

Card, S. K., Mackinlay, J. D., \& Shneiderman, B. (1999). Readings in information visualization: Using vision to think. San Francisco: Kaufmann.

Carlgren, I. (1997). Klassrummet som social praktik och meningskonstruerande kultur. Nordisk Pedagogik, 17, 8-27.

Chakravarty, R. (2008). Information literacy in the knowledge society: Empowering learners for a better tomorrow. In Trends and Strategic Issues for Libraries in Global Information Society, Chandigarh, India, 18-19 March 2008. Eds. Mahajan, P., Vohra, R., \& Chakravarty, R. Patiala: Twenty First Century Publications.

Charters, E. (2003).The use of think-aloud methods in qualitative research: An introduction to think-aloud methods. Brock Education, 12(2), 68-82.

Chen, C. (2006). Information visualization: Beyond the horizon (2nd ed.). London: Springer-Verlag London Limited.

Chen, C. (2013). Mapping scientific frontiers: The quest for knowledge visualization (2nd ed.). London: Springer.

Chen, C., \& Yu, Y. (2000). Empirical studies of information visualization: A metaanalysis. International Journal of Human-Computer Studies, 53(5), 851-866.

Cherne, L. (1982). Thoughts for the future. In R. Garland (Ed.), Microcomputers and children in the primary school, (p. 93). Lewes: Falmer.

Cuban, L. (1986). Teachers and machines: The classroom use of technology since 1920. New York: Teachers College Press.

Cuban, L. (2001). Oversold and underused: Computers in the classroom. Cambridge, MA: Harvard University Press.

Dalton, R. (2000). Citizen attitudes and political behavior. Comparative Political Studies, 33(6/7), 912-940. 
Denzin, N.K. \& Lincoln, Y.S. (2003). Strategies of qualitative inquiry. (2nd. ed.) Thousand Oaks: SAGE.

Denzin, N. K., \& Lincoln, Y. S. (2005). Introduction: The discipline and practice of qualitative research. In N. K. Denzin, \& Y. S. Lincoln (Eds.), The Sage handbook of qualitative research (3rd ed.), (pp. 1-32). Thousand Oaks, CA: Sage.

Dill, J. Earnshaw, R., Kasik, D., Vince, J., \& Wong, P.C. (Eds.). (2012). Expanding the frontiers of visual analytics and visualization [Electronic resourse]. John Dill . [et al.], Eds. London; New York: Springer.

Driscoll, M. P. (1993). Psychology of learning for instruction: Learning and instructional technology. Boston [etc.]: Allyn and Bacon.

Dunkel, E. (2007). Bridging the distance: Children's strategies on the internet. (Doctoral Thesis, Umeå University, Interactive Media and Learning; Interaktiva medier och lärande; Umeå University, Interactive Media and Learning). (18), 50.

Edwards, R., Biesta, G., \& Thorpe, M. (2009). Rethinking contexts for learning and teaching : communities, activities and networks. Eds. Richard Edwards, Gert Biesta and Mary Thorpe. New York: Routledge.

Eliot, T. S. (1952). The complete poems and plays 1909-1950. New York: Harcourt, Brace and Co.

Endsley, M. R. (1988). Design and evaluation for situation awareness enhancement. Proceedings of the Human Factors Society 32nd Annual Meeting (pp. 97-101).

Endsley, M. R. (1995). Toward a theory of situation awareness in dynamic systems. Human Factors, 37(1), 32-64.

Endsley, M. R., Bolte, B., \& Jones, D. (2004). Designing for situation awareness. London, UK: Taylor \& Francis.

Engeström, Y. (2008). Weaving the texture of school change. Journal of Educational Change, 9(4), 379-383.

Erstad, O. (2011). Digitalt kompetente skoler. In O. Erstad, \& T. E. Hauge (Eds.), Skoleutvikling og digitale medier. kompleksitet, mangfold og ekspansiv laring (pp. 46-63). Olso: Gyldendal Akademisk.

Ertmer, P. A., \& Newby, T. J. (2013). Behaviorism, cognitivism, constructivism: Comparing critical features from an instructional design perspective. Performance Improvement Quarterly, 26(2), 43-71.

European Commission. (2008). Commission staff working document: The use of ICT to support innovation and lifelong learning for all - A report on progress (No. 2629 final). Brussels: 09/10/2008 SEC.

Fenwick, T. J., \& Edwards, R. (2010). Actor-network theory in education [electronic resource] (1st ed.). London, New York: Routledge.

Fenwick, \& R. Edwards, R. (Eds.), (2012a). Researching education through actornetwork theory, UK. Wiley \& Sons, Ltd.

Fenwick, T., \& Edwards, R. (2012b). Introduction. In T. Fenwick, \& R. Edwards (Eds.), Researching education through actor-network theory (pp. iv-xxii), UK. Wiley \& Sons, Ltd.

Field, A. P., \& Hole, G. J. (2003). How to design and report experiments. London: SAGE. 
Fleischer, H. (2013). En elev - en dator: Kunskapsbildningens kvalitet och villkor $i$ den datoriserade skolan. Dissertation Series No. 21. Jönköping.

Francke, H., Sundin, O., \& Limberg, L. (2011). Debating credibility: The shaping of information literacies in upper secondary school. Journal of Documentation, 67(4), 675-694.

Francke, H., \& Gärdén, C. (2013). Forskning om informationskompetens i skolsammanhang. In L. Limberg, \& A. H. Lundh (Eds.), Skolbibliotekets roller $i$ förändrade landskap. Lind: BTJ Förlag.

Gill, T. G., \& Hicks, R. C. (2006). Task complexity and informing science: A synthesis. The International Journal of an Emerging Transdiscipline, 9, 1-30.

Giorgis, C., Johnson, N., J., Bonomo, A., Colbert, C., Conner, A., Kauffman, G., et al. (1999). Children's books: Visual literacy. The Reading Teacher, 53(2), 146153.

Goffman, E. (1981). Forms of Talk. Oxford: Basil Blackwell.

Goffman, E. (1983). The Interaction Order: American Sociological Association, 1982 Presidential Address, American Sociological Review, 48(1), 1-17.

Golafshani, N. (2003). Understanding reliability and validity in qualitative research. The Qualitative Report, 8(4), 597-607.

Goolsbee, A., \& Guryan, J. (2002). The impact of internet subsidies in public schools. National Bureau of Economic Research, Inc.

Gould, J., Lewis, D. (1985). Designing for usability: Key principles and what designers think. Commuications of the ACM, 28(3), 300-311.

Green, J., Franquiz, M., \& Dixon, C. (1997). The myth of the objective transcript: Transcribing as a situated act. TESOL Quarterly, 31(1), 172-176.

Greitzer, F., Noonan, C., \& Franklin, L. (2011). Cognitive foundations for visual analytics. (Pacific Northwest National Laboratory No. February). U.S. Springfield: Office of Scientific and Technical Information.

Greitzer, F., Schur, A., \& Guttromson, R. (2008). A sensemaking perspective on situation awareness in power grid operations. Power and Energy Society General Meeting - Conversion and Delivery of Electrical Energy in the 21st Century, 2008 IEEE, 1-6.

Gärdén, C. (2010). Verktyg för lärande: Informationssökning och informationsanvändning i kommunal vuxenutbildning. Borås: Valfrid. Diss. Göteborgs universitet.

Gärdenfors, P. (2001). How to achieve understanding with the aid of e-learning. $e$ Learning 2nd WBLE Conference, Proceedings, Lund, Sweden, 2001, 51-69.

Hahn, C. L. (2010). Comparative civic education research: What we know and what we need to know. Citizenship Teaching and Learning, 6(1), 5-23.

Halverson, R., \& Shapiro, R. B. (2012). Technologies for education and technologies for learners: How information technologies are (and should be) changing schools. (WCER Working Paper no. 2012-6).

Harasim, L. M. (2012). Learning theory and online technologies. New York; London: Routledge.

Heath, C., Hindmarsh, J., \& Luff, P. (2010). Video in qualitative research: Analysing social interaction in everyday life. Los Angeles: SAGE. 
Hedtke, R., Zimenkova, T., \& Hippe, T. (2008). A trinity of transformation, Europeanisation and democratization? Current research on citizenship education in Europe. Journal of Social Science Education, 6(2), 5-20.

Heidegger, M. (1977a). Only a god can save us now. Graduate Faculty Philosophy Journal, 6, 5-27.

Heidegger, M. (1977b). The question concerning technology, and other essays. (1st ed.). New York: Harper \& Row.

Hekman, S. J. (2010). The material of knowledge: Feminist disclosures. Bloomington, IN: Indiana University Press.

Hermansson C. (2013). Nomadic Writing: Exploring Processes Of Writing In Early Childhood Education. SwePub, Ipswich: MA.

Hilbert, M., \& López, P. (2011). The world's technological capacity to store, communicate, and compute information. Science, 1 April (332 (6025)), 60-65.

Ho, Q., Lundblad, P., Åström, T., \& Jern, M. (2011). A web-enabled visualization toolkit for geovisual analytics visualization and data analysis. Proceedings of SPIE: Electronic Imaging Science and Tech-nology, Visualization and Data Analysis, San Francisco, Jan 2011.

Ho, Q., Lundblad, P., Åström, T., \& Jern, M. (2012). A web-enabled visualization toolkit for geovisual analytics visualisation and data analysis. Information Visualization 11(1), 22-42.

Hornbæk, K. (2006). Current practice in measuring usability: Challenges to usability studies and research. International Journal of Human-Computer Studies, 64(2), 79-102.

Huff, D. (1954). How to lie with statistics. pictures by Irving Geis (1st ed. ed.). New York: Norton.

Hughes, T. P., \& Mayntz, R. (Eds.). (1988). The development of large technical systems. Frankfurt am Main: Campus Verlag.

Hultman, K. (2011). Barn, linjaler och andra aktörer: Posthumanistiska perspektiv på subjektskapande och materialitet i förskola/skola. Stockholm: Stockholms universitet.

Husbands, C., Kitson, A., \& Pendry, A. (2003). Understanding history teaching. teaching and learning about the past in secondary schools. Maidenhead and Philadephia: Open Univesity Press.

Höjgaard, L., \& Søndergaard, D. M. (2011). Theorizing the complexities of discursive and material subjectivity: Agential realism and poststructural analyses. Theory \& Psychology, 21(3), 338-354.

Jedeskog, G. (2001). "Maila mig sen!": Lärarintentioner och förändrade gränser för elevers arbete. Institutionen för beteendevetenskap, Linköpings Universitet: LiUPEK-R-226.

Jedeskog, G. \& Nissen, J. (2004). ICT in the Classroom: Is Doing More Important than Knowing?. Education and Information Technologies, 9(1), 37-45.

Jeffrey, L. M. (2009). Learning orientations: Diversity in higher education. Learning and Individual Differences, 19(2), 195-208.

Jern, M. (2010, April). Collaborative Educational Geoanalytics Applied to Large Statistics Temporal Data. CSEDU 1. INSTICC Press, 233-238. 
Jern M, (2010, May). Educating students in official statistics using embedded geovisual analytics storytelling methods. Eurographics 2010, Norrköping.

Jern, M., \& Stenliden, L. (2011). Visual Storytelling Applied to Educational World Statistics, In Statistics for policymaking: Europe 2020. (pp. 73-82). Charlemagne Building, Brussels, Eurostats.

Jern, M. Thygesen, L. Brezzi, M. (2009, March). A web-enabled Geovisual Analytics tool applied to OECD Regional Data. Eurographics 2009, Munich.

Johnsson Harrie. A. (2011), De samhällsvetenskapliga ämnenas didaktik. Rapport från en inventering [Electronic resourse], Linköping University Electronic Press, Linköping.

Johansson, V. (2012). A time and place for everything? Social visualisation tools and critical literacies. The Swedish School of Library and Information Science: The University of Borås. Skrifter från Valfrid (52).

Jones-Kavalier, Barbara R., \& Flanigan, Suzanne L. (2006). Connecting the Digital Dots: Literacy of the 21st Century. EDUCAUSE Quarterly, 29(2).

Jones, L., Holmes, R., Macrae, C., \& Maclure, M. (2010). Documenting classroom life: How can I write about what I am seeing? Qualitative Research 10(4), 479491.

Jordan, B. (1992). Technology and Social Interaction: Notes on the Achievement of Authoritative Knowledge in Complex Settings. IRL Technical Report No. IRL920027. Palo Alto, CA: Institute for Research on Learning.

Jordan, B., \& Henderson, A. (1995). Interaction analyses: Foundations and practices. The Journal of the Learning Sciences, 4(1), 39-103.

Keim, D.A., Andrienko, G., Fekete, J., Görg, C., Kohlhammer, J., \& Melançon, G. (2008). Visual analytics: Definition, process, and challenges. Information Visualization - Human-Centered Issues and Perspectives. Lecture Notes in Computer Science (Including Subseries Lecture Notes in Artificial Intelligence and Lecture Notes in Bioinformatics, (pp. 154-175). 4950 LNCS..

Keim, D. A., Kohlhammer, J., Ellis, G., \& Mansmann, F. (2010). Mastering the information age - solving problems with visual analytics. Eurographics Association, Germany, Druckhaus.

Keim, D.A., Mansmann, F., Schneidewind, J., Ziegler, H. (2006). Challenges in visual data analysis. In: Proceedings of the Conference on Information Visualization (IV 2006), (pp. 9-16), London, United Kingdom, July 5-7. IEEE, Los Alamitos.

Kell, P. (2005). Teachers' and public-sector workers' "engagement with globalization from above": Resisting regressive paraochialism in Queensland. In M. W. Apple, J. Kenway \& M. Singh (Eds.), Globalizing education: Policies, pedagogies, \& politics (pp. 247-264). New York: P. Lang.

Kendon, A. (1985). Behavioral foundations for the process of frame attunement in face-to-face interaction. In G. P. Ginsburg, M. Brenner, \& M. von Cranach (Eds.), Discovery strategies in the psychology of action (pp. 229-253). London: Academic. 
Kinzel, M., \& Wright, D. (2008). Using Geovisualizations in the Curriculum: Do Multimedia Tools Enhance Geography Education?, Environmental Systems Research Institute Education User's Conference. Paper Number 1290.

Kjällander, S. (2011). Designs for learning in an extended digital environment: Case studies of social interaction in the social science classroom. Stockholm: Department of Education, Stockholm University.

Klein, J. (1990). Interdisciplinarity: History, theory, and practice. Detroit, MI US: Wayne State University Press.

Krange, I., \& Ludvidsen, S. (2008). What does it mean? Students' procedural and conceptual problemsolving in a CSCL environment designed within the field of science education. International Journal of Computer-Supported Collaborative Learning, 3(1), 25-51.

Kress, G. R. (2003). Literacy in the new media age. London: Routledge, 2003.

Kress, G. R. (2010). Multimodality: A social semiotic approach to contemporary communication. London: Routledge.

Kress, G. R., \& Van Leeuwen, T. (2006). Reading images: The grammar of visual design. (2nd. ed.). London: Routledge.

Labov, W. (1972). Sociolinguistic patterns. Philadelphia: The University of Pennsylvania Press, INC.

Laney, D. (2001). Application delivery strategies (No. 949: Addendum). Stamford: META Group Inc.

Lantz-Andersson, A. (2009). Framing in educational practices: Learning activity, digital technology and the logic of situated action. Göteborg: Acta Universitatis Gothoburgensis.

Lapp, D., Flood, J., \& Fischer, D. (1999). Intermediality: How the use of multiple media enhances learning. Reading Teacher, 52(7), 776-780.

Larsson, H. (2012). Samhällsundervisningens föränderliga villkor. I Johnsson Harrie, A. \& Larsson, H. (red.). Samhällsdidaktik: sju aspekter på samhällsundervisning $i$ skola och lärarutbildning. Linköping: Linköpings universitet, [Forum för ämnesdidaktik].

Larsson, S. (2005). Om kvalitet i kvalitativa studier. Nordisk Pedagogik, 25(1), 1635.

Latour, B. (1987). Science in action: How to follow scientists and engineers through society. Cambridge, MA: Harvard University Press.

Latour, B. (1992). Where are the missing masses? The sociology of a few mundane artefacts. In W. Bijker, \& J. Law (Eds.), Shaping technology/building society: Studies in sociotechnical change (pp. 225-258). Cambridge, MA: MIT Press.

Latour, B. (1993). We have never been modern. Cambridge, MA: Harvard University Press.

Latour, B. (2005). Reassembling the social: An introduction to actor-network-theory. Oxford: Oxford University Press.

Latour, B., \& Woolgar, S. (1979). Laboratory life: The social construction of scientific facts. Beverly Hills: Sage.

Lauder, H., Brown, P., Dillabough, J., \& Halsey, A. H. (2006). Globalisation, Knowledge and the Myth of the Magnet Economy, Globalisation, Societies and 
Education, 4(1), 25-57. Brown, P. and Lauder, H. Reprinted in Lauder, et al. (2006) (Eds.) Education, Globalization and Social Change, (pp. 317-340). Oxford: Oxford University Press.

Lave, J., \& Wenger, E. (1991). Situated learning: Legitimate peripheral participation. Cambridge: Cambridge University Press.

Lave, J., \& Wenger, E. (1998). Communities of practice: Learning, meaning, and identity. Cambridge: Cambridge University Press.

Law, J. (1987). Technology and heterogeneous engineering: The case of Portuguese expansion. In W. E. Bijker, T. P. Hughes \& T. J. Pinch (Eds.), The social construction of technological systems: New directions in the sociology and history of technology (pp. 111-134). Cambridge, MA: MIT Press.

Law, J. (2002). Aircraft stories: Decentering the object in technoscience. Durham, NC: Duke University Press.

Law, J., \& Hassard, J. (1999). Actor network theory and after. Oxford: Blackwell.

Lee, F. (2009). Letters and bytes: Sociotechnical studies of distance education. Linköping: The Department of Thematic Studies, Technology and Social Change, Linköping University.

Lee, F. (2012). Michel Callon: En av aktör-nätverksteorins skapare. In C. Åsberg, M. Hultman \& F. Lee (Eds.), Posthumanistiska nyckeltexter (1. uppl. ed., pp. 145174). Lund: Studentlitteratur.

Limberg, L. (2005). Experiencing information seeking and learning: Research on patterns of variation. In T. Wilson, \& E. Maceviciute (Eds.), Introducing information management: An information research reader (pp. 68-80). London: Facet.

Limberg, L., \& Alexandersson, M. (2010). Learning and information seeking. In M. J. Bates, \& M. N. Maack (Eds.), Encyclopedia of library and information science (3rd ed.). New York: Taylor \& Francis.

Limberg, L., Alexandersson, M., \& Lantz-Andersson, A. (2008). To be lost and to be a loser through the web. Handbook of research on digital information technologies: Innovations, methods, and ethical issues. In T. Hansson (Ed.), Handbook of Digital Information Technologies: Innovations, methods, and ethical issues. (pp. 249-263). Hershey, PA: Information Science Reference.

Lindgren, B. (2005). Bild, visualitet och vetande: Diskussion om bild som kunskapsfält inom utbildning. Göteborg: Acta Universitatis Gothoburgensis.

Lindgren, B., \& Nordström, G. Z. (2009). Det kreativa ögat: Om perception, semiotik och bildspråk (1. uppl. ed.). Lund: Studentlitteratur.

Lorimer, J. (2013). More-than-human visual analysis. In R. Coleman \& J. Ringrose (Eds.), Deleuze and research methodologies (pp. 61-78). Edinburgh: Edinburgh University Press.

Ludvigsen, S. R. (2012). What counts as knowledge: Learning to use categories in computer environments. Learning, Media and Technology, 37(1), 40-52.

Lundblad, P. (2013). Applied geovisual analytics and storytelling. (1515), 59. Linköping: The Department of Science and Technology, Linköping University.

Lundblad, P., \& Jern, M. (2012). Visual storytelling in education applied to spatialtemporal multivariate statistics data. In J. Dill, R. Earnshaw, D. Kasik, J. Vince \& 
P. C. Wong (Eds.), Expanding the frontiers of visual analytics and visualization (pp. 175-198). London: Springer.

Lundblad, P., \& Stenliden, L. (2012). VISE - visual storytelling in school, [course resources: blog] Retrieved 09/30, 2013, from http://ncomva.se/vise/.

Lundh, A. (2010). Studying information needs as question-negotiations in an educational context: A methodological comment. Information Research: An International Electronic Journal, 15(4).

Lundh, A. (2011). Doing research in primary school: Information activities in project-based learning. Borås: Valfrid, 2011.Göteborg: Ineko.

Lundh, A., \& Limberg, L. (2008). Information practices in elementary school. Libri, $5 K 8(2), 92-101$.

Maclure, M. (2013). Coding as an analytic practice in qualitative research. In R. Coleman \& J. Ringrose (Eds.), Deleuze and research methodologies (pp. 164183). Edinburgh: Edinburgh University Press.

Manyika, J., Chui, M., Brown, B., Bughin, J., Dobbs, R., Roxburgh, C., et al. (2011). Big data: The next frontier for innovation, competition, and productivity (Research No. May) McKinsey Global Institute.

Martinsson, L., \& Reimers, E. (forthcoming). Skola i normer (II ed.). Malmö: Gleerup.

Mayer, R. (1996). The search for insight: Grappling with gestalt psychology's unanswered questions. In R. Sternberg \& J. Davidson (Eds.), The nature of insight (pp. 3-32). Cambridge, MA: MIT Press.

Mayer, R. E. (2006). Multimedia learning. Enskede: TPB.

Mayer, R. E., \& Moreno, R. (1998). A split-attention effect in multimedia learning: Evidence for dual processing systems in working. Journal of Educational Psychology, 90(2), 312-320.

Mayer, R. E., \& Moreno, R. (2002). Aids to computer-based multimedia learning. Learning and Instruction, 12(1), 107-119.

Mayer-Schönberger, V. \& Cukier, K. (2013). Big data: A revolution that will transform how we live, work, and think. London: John Murray Publishers.

McColl, E. (1994). Questionnaire design and construction. Nurse Researcher, 1(2), 16-23.

McWilliam, E., Dooley, F., McArdle, F., \& Tan, P. (2008). Voicing objections. In A. Y. Jackson, \& L. A. Mazzei (Eds.), Voice in qualitative inquiry: Challenging conventional, interpretive, and critical conceptions in qualitative research (pp. 63-75). New York, NY: Abingdon, Oxon: Routledge.

Metros, S. (2008). The educator's role in preparing visually literate learners. Theory into Practice, 47, 102-109.

Miettinen, R. (1999). The riddle of things: Activity theory and actor-network theory as approaches to studying innovations. Mind, Culture and Activity, 6, 170-195.

Mol, A. (2010). Actor-network theory: Sensitive terms and enduring tensions. Kölner Zeitschrift Für Soziologie Und Sozialpsychologie, Sonderheft, 50, 253-269.

Moreno, L. (2006). Video recording as the reflexive preservation-configuration of phenomenal features for analysis. In H. Knoblauch (Ed.), Video analysis: 
Methodology and methods: Qualitative audiovisual data analysis in sociology. (pp. 51-67). Frankfurt am Main: P. Lang.

Moreno, R., \& Mayer, R. E. (2000). A coherence effect in multimedia learning: The case for minimizing irrelevant sounds in the design of multimedia instructional messages. Journal of Educational Psychology, 92(1), 117-125.

Morgan, D. L. (1997). Focus groups as qualitative research (2nd [rev.] ed.). Thousand Oaks, CA: Sage.

Mäkitalo, Å., Jakobsson, A., \& Säljö, R. (2009). Learning to reason in the context of socioscientific problems. Exploring the demands on students in 'new' classroom activities. In K. Kumpulainen, C. Hmelo-Silver \& M. Cesar (Eds.), Investigating classroom interaction: Methodologies in action (pp. 7-25). Rotterdam: Sense.

Nesbit, J. C., \& Adescope, O. (2006). Learning with concepts and knowledge maps: A meta-analysis. Review of Educational Research, 76, 413-488.

Newbury, D. (2001). Diaries and fieldnotes in the research process. Art Design and Media, 1(Research Issues) .

Nicholson, J., Ridgway, J., \& McCusker, S. (2011). Enhancing Statistical Literacy Multivariate Thinking in Precollege. Statistical institute: Proc. 58th world statistical congress. Dublin. (Session STS008).

Nielsen, J., \& Landauer, T. K. (1993). A mathematical model of the finding of usability problems. Proceedings of ACM INTERCHI'93 Conference. Amsterdam, The Netherlands. 206-213.

Nielsen, J. (1993). Usability engineering. (2nd ed.), Morgan Kaufmann Publishers Inc. San Francisco, CA, US.

Nissen, J., Jedeskog, G., Langerth, M., Johansson, M., Edström, R. \& Samuelsson, J. (2002). "Säg IT - det räcker": Att utveckla skolan med några lysande IT-projekt: Utvärdering av KK-stiftelsens satsning på större skolutvecklingsprojekt. Stockholm: Stiftelsen för kunskaps- och kompetensutveckling.

Nunan, D. (1992). Research methods in language learning. Cambridge: Cambridge University Press.

OECD. [Organisation for Economic Cooperation and Development] (2009a). 21st century skills and competences for new millennium learners in OECD countries. OECD education working papers, no. 41, OECD Publishing.

OECD. [Organisation for Economic Cooperation and Development] (2009b). New millennium learners initial findings on the effects of digital technologies on school-age learners. Utbildningsdirektoratet: OECD. Centre for Educational Research and Innovation.

OECD. [Organisation for Economic Cooperation and Development] (2014). PISA 2012 Results: Creative Problem Solving: Students' Skills in Tackling Real-Life Problems (Volume V). PISA, OECD Publishing.

Ohlhorst, F. (2013). Big data analytics: Turning big data into big money. Hoboken, NJ: Wiley.

Olofsson, A. D., Lindberg, J. O., Fransson, G., \& Hauge, E. T. (2011). Uptake and use of digital technologies in primary and secondary schools: A thematic review of research. Nordic Journal of Digital Literacy, 4, 208-226. 
Olsson, D. (2011). Nordisk ämnesdidaktisk forskning i SO-ämnen. en inventering. Karlstad: CSD, Centrum för de samhällsvetenskapliga ämnenas didaktik.

Ongstad, S. (2006). Fag i endring. om didaktisering av kunnskap. In S. Ongstad (Ed.), Fag og didaktikk $i$ laererutdanning. kunnskap i grenseland. (pp. 19-57), Oslo: Universitetsforlaget.

Osberg, D.C. \& Biesta, G.J.J. (2008). The emergent curriculum: Navigating a complex course between unguided learning and planned enculturation. Journal of Curriculum Studies, 40(3), 313-328.

Patton, M. Q. (2004). Qualitative research \& evaluation methods (4th ed.). London: SAGE.

Piaget, J. (1970). Science of education and the psychology of the child. New York: Orion Press.

Piaget, J. (1971). The construction of reality in the child / Jean Piaget; transl. by Margaret Cook. New York: Ballantine Books.

Pickering, A. (1995). The mangle of practice: Time, agency, and science. Chicago: University of Chicago Press.

Pinch, T. J., \& Bijker, W. (1987). The social construction of facts and artifacts or how the sociology of science and the sociology of technology might benefit each other. In E. Wiebe, Bijker, P. Thomas, Hughes, J. Trevor \& T. J. Pinch (Eds.), The social construction of technological systems: New directions in the sociology and history of technology (pp. 17-50). Cambridge, MA: MIT Press.

Plester, B., Blades, M., \& Spencer, C. (2006). Mapmaking with children: Sense of place education for the elementary years. In C. Spencer \& M. Blades (Eds.), Children and their environments: Learning using and designing spaces (pp. 4256). Cambridge MA: Cambridge University Press.

Prensky, M. (2009). H. sapiens digital: From digital immigrants and digital natives to digital wisdom. Innovative - Journal of Online Education, 5(3), 1-9.

Prensky, M. (2012). From digital natives to digital wisdom: Hopeful essays for 21st century learning. Thousand Oaks, CA; London: Corwin.

Price, S. \& Rogers, Y. (2004). Let's get physical: The learning benefits of interacting in digitally augmented physical spaces. Computers and Education, 43(1-2), 137151.

Rabiee, F. (2004). Focus-group interview and data analysis. Proceedings of the Nutrition Society, 63(04), 655-660.

Ravenscroft, A. (2012). 21st century learning for 21st century skills [electronic resource]: 7th European conference of technology enhanced learning, EC-TEL 2012, Saarbrücken, Germany, September 18-21, 2012. Proceedings. Berlin; New York: Springer.

Reynolds, R., \& Vinterek, M. (2013). Globalization and classroom practice: Insights on learning about the world in Swedish and Australian schools. Nordidactica, (2013:1), 104-130.

Robinson, D. H., \& Kiewra, K. A. (1995). Visual argument: Graphic organizers are superior to outlines in improving learning from text. Journal of Educational Psychology, 87(3), 455-467. 
Rogoff, B. (1995). Observing sociocultural activity on three planes: Participatory appropriation, guided participation, and apprenticeship. In J. V. Wertsch, P. del Rio \& A. Alvarez (Eds.), Sociocultural studies of mind. (pp. 139-164). Cambridge, UK: Cambridge University Press. Reprinted (2008). In K. Hall \& P. Murphy (Eds.), Pedagogy and practice: Culture and identities. London: Sage.

Rosling, H. (2007). Visual technology unveils the beauty of statistics and swaps policy from dissemination to access. Statistical Journal of the AIOS, 24, 103-104.

Rosling, H., Rönnlund, A.R., Rosling, O. (2004). New software brings statistics beyond the eye. In: OECD World Forum on Key Indicators, Teatro Massimo, Palermo, Italia. November 10-13.

Sadler, T. D. (2009). Situated learning in science education: Socio-scientific issues as contexts for practice. Studies in Science Education, 45(1), 1-42.

Siegel, E. (2013). Predictive analytics: The power to predict who will click, buy, lie, or die. Hoboken, NJ: Wiley.

Sandahl, J. (2011). Att ta sig an världen: Lärare diskuterar innehåll och mål $i$ samhällskunskapsämnet. Karlstad: Karlstad University Press.

Sandahl, J. (2013). Being engaged and knowledgeable: Social science thinking concepts and students' civic engagement in teaching on globalisation. Nordidactica, (2013:1), 158-179.

Schleicher, A. (2011). The case for 21st century learning. OECD Observer, 282, 4243.

Schulz, W., Ainley, J., Fraillon, J., Kerr, D., \& Losito, B. (2010). International Report: Civic knowledge, attitudes, and engagment among lower-secondary schools in thirty-eight countries. International association for the evaluation of educational achievment (IEA), ICCS 2009, Rome.

Shackel, B. (2009). Usability: Context, framework, definition, design and evaluation. Interacting with Computers, 21(5-6), 339-346.

Shneiderman, B., \& Plaisant, C. (Eds.). (2005). Designing the user interface. United States of America: Pearson Education, Inc.

Solhaug, T. (2013). Trends and dilemmas in citizenship education. Nordidactica, (2013:1), 180-200.

Spanget Christensen, T. (2013). Interdisciplinarity and self-reflection in civic education. Nordidactica, (2013:1), 201-226.

Sparrman, A., \& Lindgren, A. (2010). Visual documentation as a normalizing practice: A new discourse of visibility in preschool. Surveillance \& Society, $7(3 / 4)$.

Spence, R. (2005). Rapid, serial and visual: A presentation technique with potential. Information Visualization, 1(1), 13-19.

Stafford, B. M. (2001). Revealing technologies/Magical domains. In B. M. Stafford \& T, Terpak, (eds). Devices of wonder: From the world in a box to images on a screen (pp. 1-109). Los Angeles: Getty Research Institute.

Stenliden, L. (2013a). Understanding education involving geovisual analytics. Journal of Information Technology Education: Research, 12, 283-300. 
Stenliden, L. (2013b). Visuell kultur - barns kreativa och lärande öga. In S. Pramling I., \& B. Barndom, lärande och ämnesdidaktik. (pp. 129-142). Lund: Studentlitteratur.

Stenliden, L., \& Jern, M. (2012a). How can we study learning with geovisual analytics applied to statistics? Future Internet, 4(1), 22-41.

Stenliden, L. \& Jern, M. (2011a). Visual Storytelling Applied to Educational World Statistics. EDULEARN 11 Proceedings ISBN: 978-84-615-0441-1 Depósito Legal: V-2332-2011.

Stenliden, L., \& Jern, M. (2011b). Visual storytelling - Knowledge and understanding in education. The 2nd International Multi-Conference on Complexity, Informatics and Cybernetics: IMCIC 2011.

Stenliden, L., \& Jern, M. (2012b). Visual storytelling: Knowledge and understanding in education. Journal of Systemics, Cybernetics and Informatics, 10(5), 7-13.

Stenliden, L., \& Lundblad, P. (2012/09/18). Visual storytelling $i$ skolan (blog). Retrieved 0930, 2013, from http://vise-projektet.blogspot.se/.

Strathern, M. (1996). Cutting the network. Journal of the Royal Anthropological Institute, 2(3), 517-535.

Sundin, O., Francke, H., \& Limberg, L. (2011). Practicing information literacy in the classroom: Policies, instructions and grading. Dansk Biblioteksforskning: Tidsskrift for Informations - Og Kulturformidling, 2(3), 7-17.

Swedish National Education Agency. [Skolverket]. (2009a). Redovisning av uppdrag att bedöma verksamheters och huvudmäns utvecklingsbehov avseende ITanvändningen inom förskola, skola och vuxenutbildning samt ge förslag på insatser. Stockholm: Ordförrådet AB.

Swedish National Education Agency. [Skolverket]. (2009b). Vad påverkar resultaten $i$ svensk grundskola? Kunskapsöversikt om betydelsen av olika faktorer. Stockholm: Ordförrådet AB.

Swedish National Education Agency. [Skolverket]. (2011). Social study subjects. In Curriculum for the compulsory school, preschool class and the recreation centre 2011. Stockholm: Ordförrådet AB.

Swedish National Education Agency. [Skolverket]. (2013). It-användning och itkompetens i skolan. Regeringsuppdrag, Rapport 386, Stockholm.

Swedish Research Council. [Vetenskapsrådet]. (2002). Forskningsetiska principer inom humanistisk-samhällsvetenskaplig forskning [Ethical principles for humanities and social sciences research]. Stockholm: Vetenskapsrådet.

Swedish Schools Inspectorate [Skolinspektionen]. (2011). Tvärgående granskningsaspekt: IT-användning $i$ undervisningen. (2011-09-05), 1 (18), Dnr. 40-2010:5753 Version 1.0.

Sweller, J. (1988). Cognitive load during problem solving: Effects on learning. Cognitive Science, 12(2), 257-285.

Sweller, J., Merrienboer, J. J. G. V., \& Paas, F. G. W. C. (1998). Cognitive architecture and instructional design. Educational Psychology Review, 10, 251296.

Säljö, R. (2005). Lärande och kulturella redskap: Om lärprocesser och det kollektiva minnet. Stockholm: Norstedts akademiska förlag. 
Säljö, R. (2010a). Digital tools and challenges to institutional traditions of learning: Technologies, social memory and the performative nature of learning. Journal of Computer Assisted Learning, 26(1), 53-64.

Säljö, R. (2010b). Lärande i praktiken: Ett sociokulturellt perspektiv (2. uppl. ed.). Stockholm: Norstedt.

Säljö, R., Eklund, A., \& Mäkitalo, Å. (2006). Reasoning with mental tools and physical artefacts in everyday problem-solving. In E. de Corte \& L. Verschaffel (Eds.), Instructional psychology: Past, present, and future trends. Sixteen essays in honour of Eric de Corte (pp. 73-90). Amsterdam; Boston: Elsevier.

Sørensen, E. (2009). The materiality of learning: Technology and knowledge in educational practice. Cambridge; New York, NY US: Cambridge University Press.

Talja, S. (2010). Jean Lave's practice theory. In G. J. Leckie, L. M. Given \& J. E. Buschman (Eds.), Critical theory for library and information science: Exploring the social from across the disciplines (pp. 205-220). Santa Barbara, CA: Libraries Unlimited.

TechSmith Corporation. (n.d.). Camtasia studio, (7.1st ed.), [Screen recording and Video editing application]. Okemos, Michigan: US. (Retrieved 19 June 2011 from: http://www.techsmith.com/camtasia.html.

Thomas, J. J., \& Cook, K. A. (Eds.). (2005). Illuminating the path. Los Alamitos, CA: IEEE Computer Society.

Thomas, J. J., \& Cook, K. A. (2006). A visual analytics agenda. IEEE Computer Graphics and Applications, 26(1), 10-13.

Tomaszewski, B. (2008). Producing geo-historical context from implicit sources: A geovisual analytics approach. Cartographic Journal, 45(3), 165-181.

Tomaszewski, B., \& MacEachren, A. M. (2012). Geovisual analytics to support crisis management: Information foraging for geo-historical context. Information Visualization, 11(4), 339-359.

Tomaszewski, B. M., Robinson, A. C., Weaver, C., Stryker, M., \& MacEachren, A. M. (2007). Geovisual analytics and crisis management. Proceedings of the 4th International ISCRAM Conference, May 13-16, 2007, 173-179.

Tufte, E. R. (1983). The visual display of quantitative information. Cheshire, CT: Graphic Press.

Tufte, E. R. (1997). Visual Explanations: Images and Quantities, Evidence and Narrative. Cheshire, CT: Graphics Press

Tuominen, K. Savolainen, R. Talja, S. (2005). Information literacy as a sociotechnical practice The Library Quarterly, Vol. 75(3), 329-345.

UNDP. [United Nations Development Programme]. (2007). Making globalization work for all, Annual report 2007. Office of Communications United Nations Development Programme, NY: Hoechstetter Printing Company.

UNSD. [United Nations Statistics Division]. (2007). Fundamental principles of $\begin{array}{llllll}\text { official statistics. } & \text { Retrieved } 09 & 16 & 2011, & \text { from }\end{array}$ http://unstats.un.org/unsd/dnss/gp/fundprinciples.aspx.

van Leeuwen, T. J. (2005). Introducing social semiotics / Theo van Leeuwen. London: Routledge, 2005. 
van Leeuwen, T. J. (2006). Towards a semiotics of typography. Information Design Journal, 14(2), 139-155.

Vinterek, M. (2006). Individualisering $i$ ett skolsammanhang. Stockholm: Myndigheten för skolutveckling.

Virzi, R. A. (1992). Refining the test phase of usability evaluation: How many subjects is enough? Human Factors: The Journal of the Human Factors and Ergonomics Society, 34(4), 457-468.

Vygotskij, L. S. (1978). Interaction between learning and development. In Cole M. (Ed.), Mind in society: The development of higher psychological processes. (pp 79-91). Cambridge, MA: Harvard University Press.

Vygotskij, L. S. (1986). The Development of Scientific Concepts in Childhood: Desubg of a Working Hypothesis. In Kozulin A. (Ed.), Thought and language. (pp. 146 - 209). (Rev. ed.). Cambridge, MA: MIT Press.

Warwick, P., Cremin, H., Harrison, T., \& Mason, C. (2012). The complex ecology of young people's community engagement and the call for civic pedagogues. Journal of Social Science Education, Citizenship and Community, 11(3), 65-87.

Weber, S., \& Mitchell, C. (2008). Imaging, keyboarding, and posting identities: Young people and new media technologies. In D. Buckingham (Ed.), Youth, identity, and digital media (pp. 25-47). Cambridge: MA: MIT Press.

Wertsch, J. V. (1985). Vygotsky and the social formation of mind. Cambridge, MA: Harvard University Press.

Wertsch, J. V. (1998). Mind as action. New York, Oxford: Oxford University Press.

Whiteside, J., Bennett, J., \& Holtzblatt, K. (1988). Usability engineering: Our experience and evolution. In M. Helander (Ed.), Handbook of human-computer interaction (pp. 791-817). Amsterdam: Elsevier.

Wiegand, P. (2003). School students' understanding of choropleth maps: Evidence from collaborative mapmaking using GIS. Journal of Geography, 102(6), 234242.

Wiegand, P. (2006). Learning and teaching with maps. London: Routledge.

Winter, P., \& Biesta, G. (2012). Coming into the world, uniqueness, and the beautiful risk of education: An interview with Gert Biesta by Philip Winter. In G. J. J. Biesta (Ed.), Making sense of education (pp. 109-114) Springer Netherlands.

Wittgenstein, L. (2012). Filosofiska undersökningar.[översättning: Anders Wedberg genomsedd och korrigerad av Lars Hertzberg] Stockholm: Thales, Falun: Scandbook.

Wößmann, L. (2007). International evidence on school competition, autonomy, and accountability: A review. Peabody Journal of Education, 82(2-3), 473-497. 


\section{Part B}

\section{Publications Included in the Thesis}

I. Stenliden, L. \& Jern, M. (2011a). Visual Storytelling Applied to Educational World Statistics. EDULEARN 11 Proceedings, Depósito Legal: V-2332-2011.

II. Stenliden, L. \& Jern, M. (2010). Educating Official Statistics Using Geovisual Analytics Storytelling Methods. INTED2010 Proceedings, Depósito Legal: V-845-2010.

III. Stenliden, L. \& Jern, M. (2012). How Can We Study Learning with Geovisual Analytics Applied to Statistics? Future Internet, 2012, 4(1), 22-41.

IV. Stenliden, L. (2013a). Understanding education involving geovisual analytics. Journal of Information Technology Education: Research, 12, 283-300.

V. Stenliden, L. (2014) Learning Conditions in Education Supported by Geovisual Analytics. Reviewed and submitted to: Technology, Pedagogy and Education. 



\section{Publications Included}

The articles associated with this thesis have been removed for copyright reasons. For more details about these see:

http://urn.kb.se/resolve?urn=urn:nbn:se:liu:diva-106885 


\section{Appendixes}

\section{Appendix A: Information PM at Meeting with Headmasters}

\section{Informationsvisualization}

Right now there is a great interest of Information visualiztion in society, that also concern severel research areas, where educational science is one of them. Hence, at Linköping University an ongoing Phd-study focuses on the learning condititions that will emerge in primary schools' social science classes, if tools for information visualazation are introduced in such practices. To put through that kind of study, contact with teachers has to be made. That's the reason for this invitation to a information meeting.

The visualization application that are planned to be used in the study, by the teachers in their classrooms is:

- offering the latest technology for handling large amounts of data

- interactive (table lens, scatter plot, scatter matrix, parallel coordinates, etc)

- $\quad$ shaped or will be shaped in relation to use in social science education in primary schools

- $\quad$ providing data that is relevant to the Swedish comusory school curricula

To put through the study I need:

- $\quad$ access to primary schools and permission to ask teachers for participation.

- create an interest among teachers to participate togheter with their social science classes.

- discuss the shape of the visualization application with the teachers.

- during the second semester (spring) let participating teachers to decide a teaching plan in relation to educational goals in the curicula.

The plan is then to follow the teachers and their students in the classrooms, by video recordings during the first semester next year. My hope is that this sounds interesting to you and I look forward meeting you.

Best Regards

Linnea Stenliden 
Visual Storytelling Interacting in School

Part A: Appendixes

\section{Appendix B: Information at Teacher Meeting}

Image 1

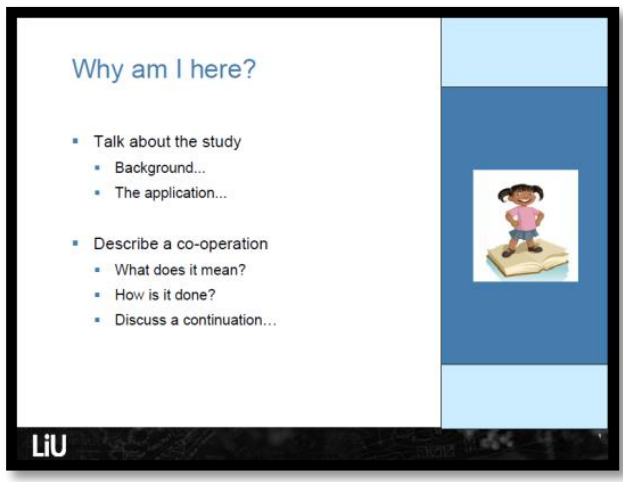

Image 3

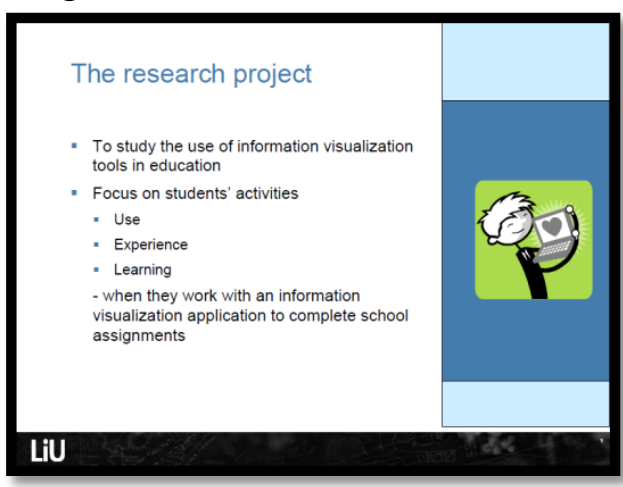

Image 5

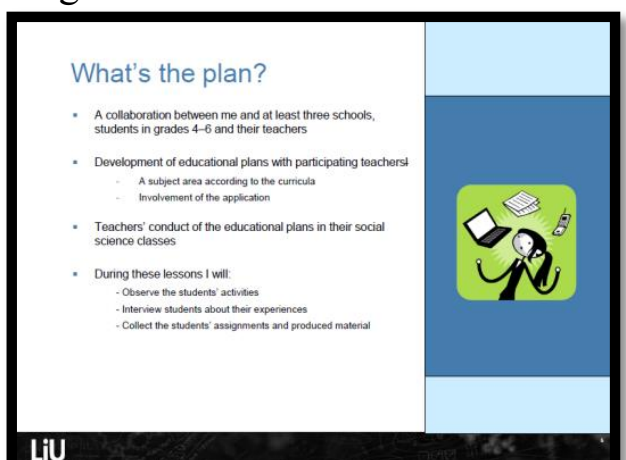

Image 2

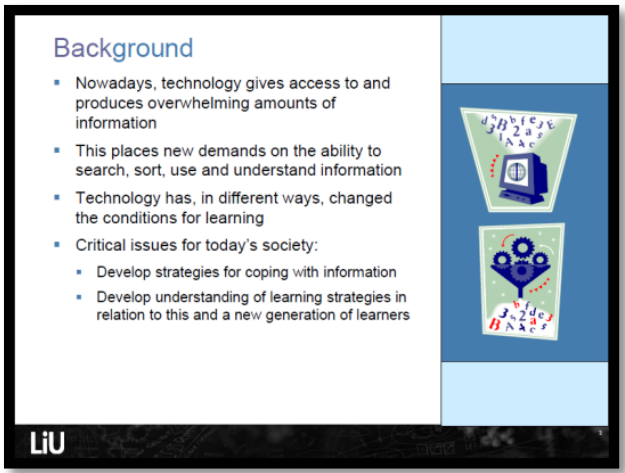

Image 4

What's that?

An Information visualization application.

Information in the form of statistics about countries, people, current state of indicators in relation to interactive maps and current state
diagrams.

diagrams.

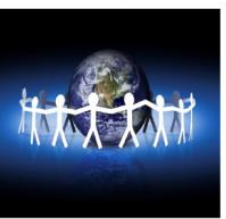

LiU

Image 6

To participate...?

- Be interested in taking part in a research project

Be interested in using information visualization in educational settings

Be willing to learn how to use the application

Think over what is suitable or relevant educational content

Take part in educational planning and development

During specific weeks of the term, conduct the education in the social science classes

Communicate an interest in taking part and reserve some time to participate 
Visual Storytelling Interacting in School

Part A: Appendixes

Image 7

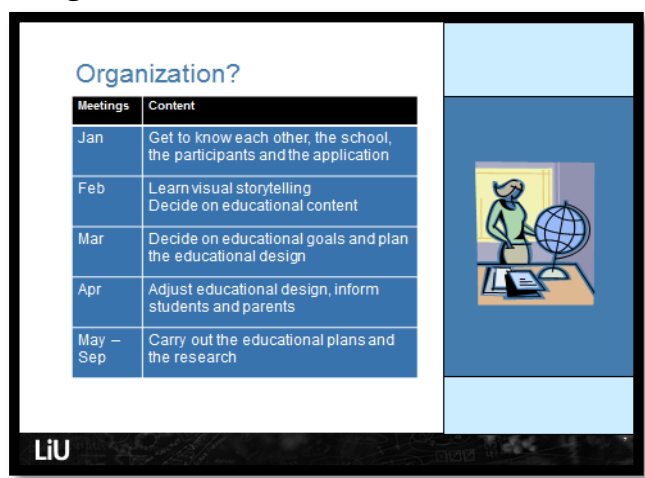

Image 8

What's in it for you?

- Be part of something unique

- Be part of learning something new

- Be part of developing new knowledge

- Develop your own professional knowledge

- Market your school and the profession's

status

- Develop your career

Fun, rewarding, challenging! 


\section{Appendix C: Interview Guide - Focus Group}

\section{Themes for discussion}

The application

- the application - overall

- the usability

$$
\begin{array}{ll}
\circ & \text { production } \\
\bigcirc & \text { presentation } \\
\bigcirc & \text { dissemination }
\end{array}
$$

- relevance for your teaching

Visual storytelling

- the content available for storytelling

- the motivs for selection of content in your storytelling

- didactic considerations made in relation to visual storytelling

○ production

$\circ$ presentation

○ dissemination

- learning visual storytelling

Teaching

- Considerations made in the presence of teaching with your Vislet

- What will happen?

- Your role as a teacher - collaboration between the content, the visuals, the assignmnets, the students

- Comparision with other educational materials

- Strategic professional way of tackling the teaching, the content, the methods 


\section{Appendix D: Educational Tasks and Coding Structure of the Questionnaire}

\section{Examples of educational tasks in the questionnaire and their coding}

\author{
Educational task \\ Explore and try to find all places displaying indicators in \\ the Vislet. How many can you find? \\ Investigate how many different indicators you can find in \\ the Vislet. \\ Investigate how to adjust the map; zoom in or out. Zoom \\ in $\mathrm{xxx}$ (the hometown) and write down the three nearest \\ towns that are displayed. \\ What happens if you adjust the button for opacity? \\ What is the GDP per capita in Sweden? \\ What continent can be characterized as one of the \\ poorest in the world (GDP per capita) \\ What country makes the most $\mathrm{CO}_{2}$ effluent in the world? \\ Compare Venezuela and Sweden and their GDP per \\ capita. Where do these two countries rank compared to \\ the rest of the world?
}

\section{Coding}

Find places where indicators

were displayed

Find different kinds of indicators

Adjust zooming

Control opacity and different levels of transparency of the map

Choose and adjust one indicator + read an amount

Search for a geographical place and read colour

Size of the bubbles Place in the diagram

The concept of the dyna-linked views

(the map/the scatter-plot and correctly read the information)

\section{Example of student assignment}

Find three municipalities where there are high employment rate

$\begin{array}{lll}\text { Interface } & \begin{array}{l}\text { Map } \\ \text { Place }\end{array} & \text { Map } \\ \text { Content } & \text { Indicator A } & \text { Indicator A } \\ \begin{array}{l}\text { Measure } \\ \text { dimension }\end{array} & \text { Text } & \\ & & \end{array}$


Starting point from map to scatterplot (place/places not titled)

\begin{tabular}{|c|c|c|}
\hline Interface & Map & Scatterplot \\
\hline Content & Indicator A & $\begin{array}{l}\text { Indicator A } \\
\text { Indicator B }\end{array}$ \\
\hline $\begin{array}{l}\text { Measure } \\
\text { dimension }\end{array}$ & $\begin{array}{l}\text { Text } \\
\text { Colour }\end{array}$ & $\begin{array}{l}\text { Text } \\
\text { Colour } \\
\text { Size } \\
\text { Place in dia }\end{array}$ \\
\hline
\end{tabular}

Starting point from map to scatterplot (place/places titled)

\begin{tabular}{|c|c|c|}
\hline Interface & Map & Scatterplot \\
\hline Content & $\begin{array}{l}\text { Place X } \\
\text { Indicator A }\end{array}$ & $\begin{array}{l}\text { Indicator A } \\
\text { Indicator B } \\
\text { Indicator } \mathrm{C}\end{array}$ \\
\hline $\begin{array}{l}\text { Measure } \\
\text { dimension }\end{array}$ & $\begin{array}{l}\text { Text } \\
\text { Colour }\end{array}$ & $\begin{array}{l}\text { Text } \\
\text { Colour } \\
\text { Size } \\
\text { Place in dia }\end{array}$ \\
\hline
\end{tabular}

Starting point from map to scatterplot (comparison titled places $(X+Y)$ )

$\begin{array}{lll}\text { Interface } & \text { Map } & \text { Scatterplot } \\ \text { Content } & \begin{array}{l}\text { Place } X+Y \\ \text { Indicator } A\end{array} & \text { Indicator } A \\ \text { Measure } & \text { Text } & \begin{array}{l}\text { Text } \\ \text { Colour } \\ \text { dimension }\end{array} \\ & & \begin{array}{l}\text { Size } \\ \text { Place in diagram }\end{array}\end{array}$

Starting point from map to scatterplot (comparison two indicators and titled places $(X+Y)$ )

$\begin{array}{lll}\text { Interface } & \text { Map } & \text { Scatterplot } \\ \text { Content } & \begin{array}{l}\text { Place } X+Y \\ \text { Indicator } A\end{array} & \begin{array}{l}\text { Indicator A } \\ \text { Indicator B }\end{array} \\ \begin{array}{lll}\text { Measure } \\ \text { dimension }\end{array} & \text { Text } & \begin{array}{l}\text { Text } \\ \text { Colour } \\ \text { Size }\end{array}\end{array}$

Example of student assignment

Compare the distribution of old and young populations

in the world

Compare the number of cars in Sweden with the country's income/ capita and $\mathrm{CO}_{2}$ emissions.

Compare the violence rate in Sweden with that in Spain

Compare birth rates and life expectancy in China and the USA. 
Starting point from map to scatterplot

Place in diagram

(comparison three indicators titled places $(X+Y)$ )

$\begin{array}{lll}\text { Interface } & \text { Map } & \text { Scatterplot } \\ \text { Content } & \begin{array}{l}\text { Place } X+Y \\ \text { Indicator A }\end{array} & \begin{array}{l}\text { Indicator A } \\ \text { Indicator B } \\ \text { Indicator C }\end{array} \\ \text { Measure } & \text { Text } & \text { Text } \\ \text { dimension } & \text { Colour } & \text { Colour } \\ & & \text { Size } \\ & & \text { Place in diagram }\end{array}$

Example of student assignment

Compare access to and consumption of fresh water and annual precipitation amounts, in Nigeria and Niger. What do you find?

Starting point from map to scatterplot (comparison titled places $(X+Y)$ one indicator in form of least)

$\begin{array}{llll}\text { Interface } & \text { Map } & \text { Scatterplot } & \begin{array}{l}\text { Compare which country that make } \\ \text { the least } \mathrm{CO}^{2} \text { combustion per capita } \\ \text { India or Sweden? }\end{array} \\ \begin{array}{lll}\text { Measure } \\ \text { dimension }\end{array} & \begin{array}{l}\text { Place } X+Y \\ \text { Indicator } A\end{array} & \text { Indicator } A & \text { Text } \\ \text { Colour } & \begin{array}{l}\text { Text } \\ \text { Colour } \\ \text { Size } \\ \text { Place in diagram }\end{array}\end{array}$

Starting point from map to scatterplot (comparison titled places $(X+Y)$ one indicator in form of most)

\begin{tabular}{|c|c|c|c|}
\hline Interface & Map & Scatterplot & $\begin{array}{l}\text { Compare which country, Japan or } \\
\text { Nigeria that have the eldest }\end{array}$ \\
\hline Content & $\begin{array}{l}\text { Place } \mathrm{X}+\mathrm{Y} \\
\text { Indicator A }\end{array}$ & Indicator A & population. \\
\hline $\begin{array}{l}\text { Measure } \\
\text { dimension }\end{array}$ & $\begin{array}{l}\text { Text } \\
\text { Colour }\end{array}$ & $\begin{array}{l}\text { Text } \\
\text { Colour } \\
\text { Size } \\
\text { Place in diagram }\end{array}$ & \\
\hline
\end{tabular}


Starting point from scatterplot to map (no titled place/places (X) two indicators)

Interface

Map

Scatterplot

Content

$\begin{array}{ll} & \text { Place X } \\ \text { Indicator A } & \text { Indicator B }\end{array}$

Measure

Text

Text

dimension
Colour

Size

Place in diagram
Example of student assignment

Investigate the density of old population in Europe (old people) can you draw any conclusions?

Starting point from scatterplot to map (no titled place/places $(X+Y)$ two indicators)

Interface

Map

Scatterplot

Content

Place $X+Y$

Indicator A

Indicator B

Measure

Text

Text

dimension

Colour

Colour

Size

Place in diagram

Compare countries with high density of young population and high density of old population? What do you find?

Compare population distribution (old people and children) with economic income per capita. What do you find?

$\begin{array}{lll}\text { Measure } & \text { Text } & \text { Text } \\ \text { dimension } & \text { Colour } & \text { Colour } \\ & & \text { Size } \\ & & \text { Place in diagram }\end{array}$

Starting point from scatterplot to map (no titled place/places $(X+Y)$ three indicators)

Interface Map Scatterplot

Content

Place $\mathrm{X}+\mathrm{Y}$

Indicator A

Indicator B

Indicator $\mathrm{C}$ 


\section{Appendix E: Think-Aloud Interview Guide}

\section{A. Students' assignments:}

http://vise-projektet.blogspot.se/ that were used during the interviews.

\section{B. Follow-up questions:}

- What are the experiences of and the meaning to children when using the technique of information visualization in pedagogical practices?

- What do you do when you work with the application?

- What is it like to work with the application?

- How do you learn with help of the application?

○ Are there any differences to work with the application compared to what you are used to, if so, what are they

- What do children perceive and how do they interpret symbols and representations in an information visualization application?

- Describe what "this" is (different features and different datatypes)

- What colours are there in the application?

○ How are the colours used, what do they mean?

- What do the different forms mean?

- How do the indicators work?

- How does the diagram work?

- How do children interact with an information visualization application and what does the interaction mean to the learning process?

- How are you supposed to do when you are gioing to find out something with help of the application?

$\circ \quad$ What differences, if any, are there between an ordinary map and this map and the diagram?

○ How does the interactivity affect your work?

- What knowledge and abilities do children develop by using an information visualization application?

- What do you develpop when you work like this?

○ What kind of knowledge do you learn when workning like this? 


\section{Appendix F: Template of Teachers' Educational Plan}

\section{Teaching plan}

Title:

Subject:

Teachers involved:

Time period:

Goals in curricula:

Educational goals:

Overview of content:

- Vislet

- Map level

- Indicators

Activities and assignments:

Material:

Organization:

Evaluation:

Feedback: 


\section{Appendix G: Letter of Assent from Students and Consent of Parents}

\section{$\mathrm{Hi}$, all children in grade $\mathrm{x}$, at $\mathrm{xx}$-school and caretakers as well}

Right now, there is an ongoing research study in the municipality of XX that tries to understand how technology for visual storytelling can be shaped and used in relation to social science education in primary school.

I would like to inform you, the students, and you, parents, about the study and ask the students about assent for participation and for the parents' consent. To participate in the study means: during XX's lessons in social science, an information visualisation application is going to be involved. The students will work with the application during these lessons for 2 - 4 weeks and my intention is to write field notes, to video document and to conduct interviews with the students during that period. Of course participation is voluntary and the involvement can at any time be terminated. All the material, field notes, video films etc will be treated with confidentiality and only be used for research purposes. I have hopes that this sounds interesting and exciting to be part of. For any question please contact me: Linnea Stenliden xxxx-xxxxxxx, or Jörgen Nissen xxxx-Xxxxxx eller till XX (name of teacher) XX (telephone number).

Best regards

Linnéa

Stenliden

PhD student, Linköpings universitet

I would like to participate

Signature child

I don't want to participate

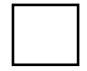

I give permission for my child to participate

I don't allow my child to participate

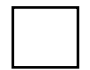

Signature care-giver 
Visual Storytelling Interacting in School

Appendixes 


\section{LINKÖPING STUDIES IN PEDAGOGIC PRACTICES}

1. MARKSTRÖM, ANNE-MARIE. Förskolan som normaliseringspraktik. En etnografisk studie. 2005. ISBN 91-85297-70-4.

2. WEDIN, ANN-SOFI. Lärares arbete och kunskapsbildning. Utmaningar och inviter i den vardagliga praktiken. 2007. ISBN 978-91-85715-63-3.

3. BRÜDE SUNDIN, JOSEFIN. En riktig rektor. Om ledarskap, genus och skolkulturer. 2007. ISBN 978-91-85715-62-6.

4. HELLBERG, KRISTINA. Elever på ett anpassat individuellt gymnasieprogram: skolvardag och vändpunkter. 2007. ISBN 978-9185831-92-0.

5. SPARRLÖF, GÖRAN. Vi manliga lärare Folkskolans lärare och lärarinnor i kamp om löner och arbetsvillkor 1920-1963. 2007. ISBN 978-91-85831-38-8.

6. KARLSSON, YVONNE. Att inte vilja vara problem - social organisering och utvärdering av elever i en särskild undervisningsgrupp. 2008. ISBN 978-91-85895-28-1.

7. OLSON, MARIA. Från nationsbyggare till global marknadsnomad. Om medborgarskapet i svensk utbildningspolitik under 1990-talet. 2008. ISBN 978-91-7393-890-7.

8. AYTON, KATARINA. An ordinary school child. Agency and authority in children's schooling. 2008. ISBN 978-91-7393-834-1.

9. BOLANDER, EVA. Risk och bejakande. Sexualitet och genus i sexualupplysning och undervisning i TV. 2009. ISBN 978-91-7393-6859.

10. JOHNSSON HARRIE, ANNA. Staten och läromedlen. En studie av den svenska statliga förhandsgranskningen av läromedel 1938-1991. 2009. ISBN 978-91-7393-616-3.

11. HÖGBERG, RONNY. Motstånd och konformitet. Om manliga yrkeselevers liv och identitetsskapande i relation till kärnämnena. 2009. ISBN 978-91-7393-543-2.

12. HEGENDER, HENRIK. Mellan akademi och profession. Hur lärarkunskap formuleras och bedöms i verksamhetsförlagd lärarutbildning. 2010. ISBN 978-91-7393-526-5. 
13. SEVERINSSON, SUSANNE. Unga i normalitetens gränsland.

Undervisning och behandling i särskilda undervisningsgrupper och hem för vård eller boende. 2010. ISBN 978-91-7393-402-2.

14. WIDÈN, PÄR. Bedömningsmakten. Berättelser om stat, lärare och elev, 1960-1995. 2010. ISBN 978-91-7393-372-8.

15. SANDLUND, MONICA. Lärare med utländsk bakgrund. Sju yrkeslivsberättelser om möten med nya skolsammanhang. 2010. ISBN 978-91-7393-371-1.

16. LILJA, PATRIK. Contextualizing inquiry. Negotiations of tasks, tools and actions in an upper secondary classroom. 2012. ISBN 978-91-7346735-3.

17. FREDRIKSSON, KRISTINA. Drama som pedagogisk möjlighet. En intervjustudie med lärare i grundskolan. 2013. ISBN 978-91-7519-6138.

18. BENGTSSON, JENNY. Jag sa att jag älskade han men jag har redan sagt förlåt för det. Ålder, genus och sexualitet i skolans tidigare år. 2013. ISBN 978-91-7519-560-5.

19. LAGO, LINA. "Mellanklass kan man kalla det". Om tid och meningsskapande vid övergången från förskoleklass till årskurs ett. 2014. ISBN 978-91-7519-349-6. 


\section{LINKÖPING STUDIES IN EDUCATION AND SOCIAL SCIENCES}

1. SEVERINSSON, SUSANNE. (2010). Unga i normalitetens gränsland. Undervisning och behandling i särskilda undervisningsgrupper och hem för vård eller boende. (Doktorsavhandling) ISBN 978-91-7393-402-2.

2. FREDRIKSSON, KRISTINA. (2013). Drama som pedagogisk möjlighet. En intervjustudie med lärare i grundskolan. (Lic) ISBN 978-91-7519-6138.

3. BENGTSSON, JENNY. (2013). Jag sa att jag älskade han men jag har redan sagt förlåt för det. Ålder, genus och sexualitet i skolans tidigare år. (Doktorsavhandling) ISBN 978-91-7519-560-5.

4. ELFSTRÖM PETTERSSON, KATARINA. (2013). Playing a part in preschool documentation. A study of how participation is enacted in preschool documentation practices and how it is affected by material agents. (Lic) ISBN 978-91-7519-339-7.

5. LAGO, LINA. (2014). "Mellanklass kan man kalla det." Om tid och meningsskapande vid övergången från förskoleklass till årskurs ett. (Doktorsavhandling) ISBN 978-91-7519-349-6. 
